\title{
Arsenic in the Baltic Sea sediments - past, present, and future
}

\author{
M. Szubska \& J. Bełdowski \\ Institute of Oceanology of the Polish Academy of Sciences, Sopot, Poland
}

\begin{abstract}
Baltic Sea is a very specific water body. Its geographical situation, geological development, hydrological features and physical drivers, make it very susceptible to pollutants, including arsenic contamination. Baltic Sea is surrounded by nine countries with different industrialization levels, affecting the riverine outflow and surface runoff into the sea. Some parts of the Baltic Sea are characterized with highly elevated arsenic concentrations resulting from the anthropogenic activity on land. There is also a significant inner source of arsenic in the Baltic - arsenic containing Chemical Warfare Agents (CWA) from chemical munitions dumped after the World War II and remaining on the sea bottom.
\end{abstract}

\section{INTRODUCTION}

Baltic Sea is one of the biggest brackish water bodies on earth. It is a non-tidal, epicontinental sea - partly cut off from the ocean. Its shape and location make it unique on a global scale. Geographical position, geological development, hydrographical features and physical drivers together create the Baltic Sea environment. The presence of particular separate basins plays role in the transport of water masses, chemical substances and sedimentary material. Therefore different areas of the Baltic Sea are characterized by diversified hydrological properties of water masses, variable bottom types and sediment composition (SnoeijsLeijonmalm et al., 2017; Szubska, 2018).

Baltic Sea is directly surrounded by nine countries, with five more within the drainage area (Fig. 1).

The drainage area is about 4 times bigger than the area of the Baltic Sea itself, heavily industrialized and relatively polluted. Large input of freshwater results in low salinity and characteristic salinity gradient due to mixing with saline waters entering via the straits of the Kattegat. This limited inflow of oceanic water masses results in a long residence (turnover) time, estimated on 30-40 years for the whole volume of Baltic waters (Snoeijs-Leijonmalm et al., 2017). As a result, all compounds which entered the Baltic Sea are circulating for a very long time. And due to the increase of anoxic and hypoxic areas in the Baltic Sea, arsenic might be released from the sediments and enter the biogeochemical cycle in its most harmful form.

\section{METHODS/EXPERIMENTAL}

Presented study is a summary of literature data on arsenic concentrations in Baltic Sea sediments and authors own research.

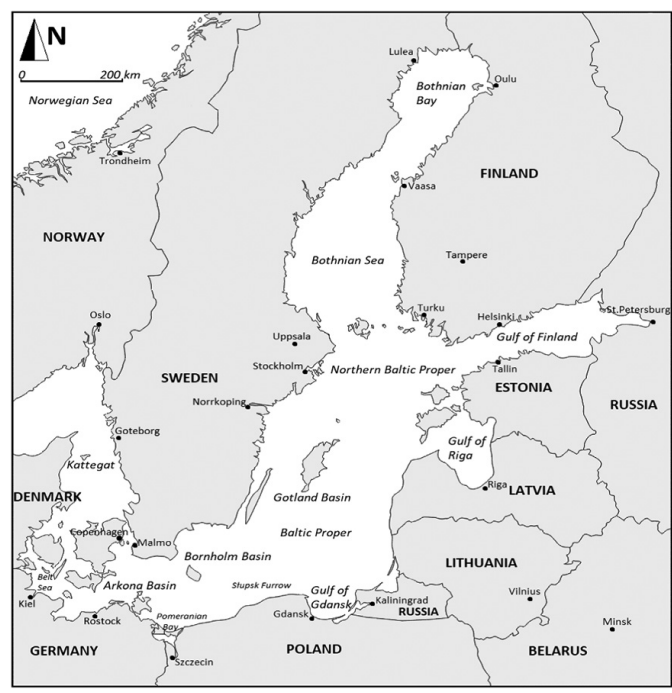

Figure 1. Location, subdivision and surrounding of the Baltic Sea.

\subsection{Analytical methods}

For total arsenic concentrations measurements Atomic Absorption Spectrometry with Hydride Generation (HG-AAS) was used. Sediment samples underwent dry digestion in $550^{\circ} \mathrm{C}$ and were dissolved in $\mathrm{HCl}$ before analysis.

Arsenic speciation was analyzed with IonExchange Chromatography column (CF-Kit-As35) combined with Inductively Coupled Plasma Mass Spectrometry (ICP-MS). Samples extraction with $\mathrm{H}_{3} \mathrm{PO}_{4}$ in microwave was conducted to obtain concentrations of As(III), As(V), MMA, DMA and arsenobetaine AsB. 


\section{RESULTS AND DISCUSSION}

\subsection{Overall view}

In the area of most countries surrounding the Baltic Sea, levels of arsenic in top soil and stream sediment are very low. This part of northern Europe can be characterized by the lowest concentrations of arsenic in soils on the whole continent. Only the area of Northern Sweden stands out of this trend, exceeding $9 \mu \mathrm{g} / \mathrm{g}$ in subsoil, topsoil and reaching up to $36 \mu \mathrm{g} \cdot \mathrm{g}^{-1}$ in stream sediments, as it stays under the strong influence of mining (Uścinowicz, 2011; Salminen, 2005). Total arsenic concentration levels in Baltic Sea bottom sediments are highly variable and depend on the distance from arsenic source and its type, as well as on the type of sediments covering the bottom and environmental conditions. They vary spatially over a very wide range from 0.3 to $277 \mu \mathrm{g} / \mathrm{g}$ (Uścinowicz, 2011).

In the oscillating oxygen conditions in eutrophic areas of the Baltic Sea, deposits of iron-manganese concretions forming a large storage of arsenic and phosphorus may be an inner source of arsenic returning to the biogeochemical cycle as the concretions may dissolve through microbial reactions in anoxic conditions. A preliminary research was made on arsenic speciation in sediments from southern Baltic Sea and until now only $\mathrm{As}(\mathrm{V})$ was noted in samples collected in areas with different oxygen levels.

\subsection{Arsenic in heavily contaminated Bothnian Bay}

Bothnian Bay is one of the most polluted areas of the Baltic Sea and arsenic is assumed to be the biggest threat of all pollutants in this area. Arsenic loads to the Bothnian Bay sediments origin from the Rönnskärsverket smelter in Sweden and may be harmful to marine organisms (Vallius, 2014). Arsenic concentrations were increasing since the middle 1970s and in the $1990 \mathrm{~s}$ reached up to $100 \mu \mathrm{g} / \mathrm{g}$. Even though the cessation of smelter activity arsenic levels declined only slightly after reaching this maximum and still remain elevated comparing to other areas.

\subsection{Arsenic in chemical ammunition dumpsites}

Nearly 30000 tons of chemical weapons, including 10000 tons of arsenic based Clark I and II, Lewisite and Adamsite, were dumped in the Baltic Se. Sediments in the dumping areas are characterized with significantly higher As concentrations in comparison with reference areas. Even though the concentrations are lower than in the area of Bothnian Sea, it is worth to point out a different behavior of arsenic in dumpsite areas in terms of correlation between As concentrations and such parameters as organic matter contents, sediment grain size, iron and manganese concentrations in samples with and without detected arsenic based CWA.

\section{CONCLUSIONS}

Even though the concentrations of arsenic are relatively low in most compartments of the Baltic Sea environment, it is still worth observing and understanding the processes occurring in this ecosystem. Specificity of the Baltic Sea (steep salinity and temperature gradients, oxygen deficiency in deep basins and different sediment coverage) makes it impossible to compare this sea with oceanic ecosystems and the results of arsenic research concerning other regions. Also the issue of arsenic speciation was already raised by other researchers, studying both marine and freshwater ecosystems, however so far there is no information on the behavior of arsenic species in marine waters with very low salinity - like the brackish waters of the Baltic Sea. Changing environment of the Baltic Sea may result in fluctuations of parameters controlling arsenic release from the sediments, including the most toxic arsenic species - As (III).

\section{ACKNOWLEDGEMENTS}

Presented results were compiled within a research grant "Arsenic speciation in the environment of southern Baltic Sea" nr 2016/21/N/ST10/03245 financed by the National Science Centre, Poland. Particular results were obtained within NATO SPS G4589 project "MODUM", \#069 CHEMSEA and \#013 DAIMON partly financed by European Union European Regional Development Fund under the Interreg Baltic Sea Region Programme 2007-2013/2014-2020.

\section{REFERENCES}

Salminen, R. (ed.) 2005. Geochemical atlas of Europe. Available on-line at: http://weppi.gtk.fi/publ/foregsatlas/

Snoeijs-Leijonmalm, P., Schubert, H. \& Radziejewska, T. (eds) 2017. Biological Oceanography of the Baltic Sea. Springer.

Szubska, M. 2018. Arsenic in the environment of the Baltic Sea - a review. In T. Zieliński, I. Sagan, W. Surosz (eds), Inter-disciplinary approaches for Sustainable Development Goals. Springer Series, GeoPlanet, Earth Planet. Sci. (in press).

Uścinowicz, S. (ed.) 2011. Geochemistry of Baltic Sea surface sediments. Polish Geological Institute - National Research institute. Warsaw, Poland.

Vallius, H. 2014. Heavy metals concentrations in sediment cores from the northern Baltic Sea: Declines in the last two decades. Mar. Pollut. Bull. 78: 359-364. 


\title{
The role of aquifer flushing on groundwater arsenic across a $35-\mathrm{km}$ transect in the upper Brahmaputra River in Assam, India
}

\author{
R. Choudhury ${ }^{1}$, C. Mahanta ${ }^{1}$, M.R. Khan ${ }^{2}$, B. Nath $^{3}$, T. Ellis ${ }^{3}$ \& A. van Geen ${ }^{3}$ \\ ${ }^{1}$ Department of Civil Engineering, Indian Institute of Technology, Guwahati, Assam, India \\ ${ }^{2}$ Department of Geology, University of Dhaka, Dhaka, Bangladesh \\ ${ }^{3}$ Lamont-Doherty Earth Observatory of Columbia University, Palisades, NY, USA
}

\begin{abstract}
In contrast to high concentrations observed near the Brahmaputra River in Bangladesh, well testing in an upstream portion of floodplain in the Indian state of Assam has shown groundwater arsenic (As) concentrations increasing with distance from the river. To study the cause of this pattern, over 900 wells $<60 \mathrm{~m}$ deep were tested for As and 9 sites were drilled manually over the same depth range along a $35-\mathrm{km}$ transect perpendicular to the river. No relation was observed between groundwater As concentrations ranging from $<0.04$ to $660 \mu \mathrm{g} \mathrm{L}^{-1}$ along the transect and the As $<1-5 \mathrm{mg} \mathrm{kg}^{-1}$ content of recovered sand cuttings. Drilling showed a marked increase in the thickness of a clay layer capping the aquifer starting from $<5 \mathrm{~m}$ closest to the river to $>60 \mathrm{~m}$ at the most distant site near the base of the Naga foothills. Radiocarbon ages of 18-46 kyr indicate pre-Holocene deposition of the underlying sands across the entire transect. With the exception of two drill sites closest to the river, the cuttings were consistently grey and indication of reduced Fe oxides. Radiocarbon ages of DIC of $0.2,4.7$, and $17.8 \mathrm{kyr}$ were measured in groundwater from 3 monitoring wells installed to $30-60 \mathrm{~m}$ depth at distances of 10,20, and $40 \mathrm{~km}$ from the river, respectively. A conceptual groundwater flow model consistent with monitored heads and groundwater ages suggests that thick clay layers capping the aquifer inhibited the flushing of As towards the foothills and, as a result, maintained higher levels of As in the groundwater.
\end{abstract}

\section{INTRODUCTION}

Elevated arsenic (As) concentrations in well water is a major public health concern for over 100 million people across South and Southeast Asia (Smedley \& Kinniburgh, 2002). Reductive dissolution of $\mathrm{Fe}(\mathrm{III})$ oxyhydroxides minerals has emerged as the leading mechanism for As release to groundwater (Bhattacharya et al., 1997). Yet, several key factors including the relative importance of sedimentary and advected sources of reduced carbon for dissolution of $\mathrm{Fe}(\mathrm{III})$ oxides remain poorly understood (Datta et al., 2011). This is one a reason why As heterogeneity across different regions has been difficult to explain (Winkel et al., 2011).

This study aims to understand the underlying processes contributing to spatial As variability along a $35 \mathrm{~km}$ transect in the upper Brahmaputra floodplains in India, where observed patterns demonstrates groundwater As concentrations increasing with distance from the river.

\section{METHODS AND EXPERIMENTAL}

\subsection{Groundwater sampling and analysis}

private and public wells $<60 \mathrm{~m}$ deep straddling the districts of Golaghat and Jorhat in the upper Brahmaputra Valley bounded by the Brahmaputra River to the north, and Naga Patkai Hill ranges in the south were analyzed using a field kit between June and
August 2015, and an additional 136 wells in November 2015.

\subsection{Sediment sampling and analysis}

Sediment cuttings were recovered from 9 boreholes drilled along a $35-\mathrm{km}$ transect perpendicular to the Brahmaputra river. At 3 of the drill sites located 10, 20 , and $40 \mathrm{~km}$ from the river, respectively, monitoring wells screened at 45,32 , and $57 \mathrm{~m}$ depth were installed. Field analysis included reflectance measurement using a CM700d diffuse reflectance spectrophotometer and bulk solid phase estimation using an InnovX Delta Premium X-ray fluorescence analyzer. Field data were complemented by radiocarbon dates for organic carbon in a set of clay cuttings and dissolved inorganic carbon (DIC) in groundwater samples collected from 3 monitoring wells installed along the same transect. The various observations are then linked with a simplified 2-D cross sectional groundwater flow model that extends from the Naga foothills to the center of the Brahmaputra river.

\section{RESULTS AND DISCUSSION}

\subsection{Groundwater and sediment data}

Field kit data for a total 913 wells $<60 \mathrm{~m}$ deep indicate that $33 \%$ of wells in the area met the WHO guideline of $10 \mu \mathrm{g} \mathrm{L}^{-1}$ for As in drinking water and are mostly concentrated within $10 \mathrm{~km}$ of the main course 
of the Brahmaputra. Another 21\% contained $>10$ to $50 \mu \mathrm{g} \mathrm{L}^{-1}$, and $46 \%$ samples exceeded $50 \mu \mathrm{g} \mathrm{L}^{-1}$ and concentrated within $10 \mathrm{~km}$ of the Naga foothills. Comparison of field and laboratory data for a subset of 288 wells confirms that the kit results are by and large consistent with the ICP-MS measurements, with $94 \%$ of wells containing $<10 \mu \mathrm{g} \mathrm{L}^{-1}$ As and $83 \%$ of the wells with $>50 \mu \mathrm{g} \mathrm{L}^{-1}$ correctly classified by the kit.

Borehole lithology indicates a marked increase in thickness of a surface clay layer starting from none to $<5 \mathrm{~m}$ at the 3 sites closest to the river to $60 \mathrm{~m}$ of almost continuous clay at the most distant site near the base of the Naga foothills. The reflectance data indicate particularly reduced $\mathrm{Fe}$ oxides $(\Delta \mathrm{R}<0.1 \%$, Horneman et al., 2004) prevail in the middle portion of the transect when compared to both the less reduced sands above the layer of brown sand at the site closest to the river and the thinner sand layers at two sites closer to the Naga Hills.

Bulk As concentrations measured by X-ray fluorescence in as many as 121 of total 147 analyzed sand cuttings were below the limit of detection of 1.4 $1.8 \mathrm{mg} \mathrm{kg}^{-1}$ calculated by the manufacturer's software. Concentrations of As in the remaining samples range from 1.5 to $4.6 \mathrm{mg} \mathrm{kg}^{-1}$, without any clear pattern distinguishing drill sites close to the Brahmaputra River and the Naga Hills.

Cuttings were also analyzed for exchangeable As with the field kit. Readings were limited to 0 and $10 \mu \mathrm{g}$ $\mathrm{L}^{-1}$ As for all 49 samples of sand cuttings from the 5 sites closest to the river. The corresponding range in leachable As concentrations is $0-1 \mathrm{mg} \mathrm{kg}^{-1}$ without adjustment in reference chart. Out of the 9 samples of sand cuttings analyzed from the 4 sites closest to the Naga Hills instead, 3 samples gave readings of 25 and $50 \mu \mathrm{g} \mathrm{L}^{-1}$ corresponding to $2.5-5 \mathrm{mg} \mathrm{kg}^{-1}$ leachable As.

With the exception of one shallow sample at $0.3 \mathrm{~m}$ bgl, uncorrected radiocarbon age of organic matter in all clay cuttings ranged from 18 to $46 \mathrm{kyr}$, indicating pre-Holocene ( $>12 \mathrm{kyr}$ ) deposition along most of the transect. Uncorrected DIC ages for groundwater span a wide range from $0.2 \mathrm{kyr}$ at site closest to river to $4.7 \mathrm{kyr}$ near the middle of the transect and $17.8 \mathrm{kyr}$ closest the Naga Hills.

Measured groundwater levels range from 2 to $10 \mathrm{~m}$ below the local land surface across the transect. When referred to a constant datum, shallow groundwater elevations decrease $95 \mathrm{~m}$ near the hills to $80 \mathrm{~m}$ at the river, corresponding to a lateral head gradient of $0.3 \times 10^{-3}$.

Observed spatial pattern along the $35 \mathrm{~km}$ transect can only partially be explained by difference in extent of reduced Fe oxide in aquifer sediment. Redox of the sediment alone cannot account for the trend in groundwater because the most reduced sands prevail in the middle portion of the transect instead of the region closest to the Naga Hills.

\subsection{Groundwater flow modeling}

Among the different groundwater flow models that were tested, the best fit model that replicated field observations was the one where a constant head boundary near the hill was assumed. The implication is that water recharges far from the transect and flows a considerable distance before reaching it. It is therefore already old when it reaches the hillside boundary of the transect and ages further while flowing towards the river. The model indicates that thickness of this flow-system depends on the horizontal hydraulic conductivity as well as the recharge rate.

\section{CONCLUSIONS}

Observed increase in As concentrations in shallow aquifers, with distance away from the Brahmaputra River documented in this study can be attributed to flushing of exchangeable As playing a dominant role. High surface permeability and therefore recharge and flushing of coarse sands closest to the Brahmaputra River has flushed the aquifers of their exchangeable As. In contrast, such flushing was inhibited by the thick clay capping aquifers near the Naga foothills.

\section{ACKNOWLEDGEMENTS}

This study was supported by a grant from $\mathrm{CE} / \mathrm{C} / \mathrm{CM} / 57$ to CM, a Fulbright fellowship to RC, US NIEHS grant P42 ES10349, and US NSF ICER 1414131. We are grateful to PHED Assam for their generous support. We also thank the students of IIT Guwahati, Dr. Chander Kumar Singh and Imtiaz Choudhury for their help in the field.

\section{REFERENCES}

Bhattacharya, P., Chatterjee, D. \& Jacks, G. 1997. Occurrence of arsenic-contaminated groundwater in alluvial aquifers from Delta Plains, Eastern India: Options for Safe Drinking Water Supply. Int. J. Water Res. Dev. 13(1): 79-92.

Datta, S., Neal, A., Mohajerin, W., Ocheltree, T., Rosenheim, B.E., White, C.E. \& Johannesson, K.H. 2011. Perennial ponds are not an important source of water or dissolved organic matter to groundwaters with high arsenic concentrations in West Bengal, India. Geophys. Res. Lett. 38: L20404. 8(20): 582-582.

Horneman, A., van Geen, A., Kent, D.V., Mathe, P.E., Zheng, Y., Dhar, Y.R., Oonnell, S., Hoque, M.A., Aziz, Z., Shamsudduha, M., Seddique, A.A. \& Ahmed, K.M. 2004. Decoupling of As and Fe release to Bangladesh groundwater under reducing conditions. Part I: Evidence from sediment profiles. Geochim. Cosmochim. Acta 68(17): 3459-3473.

Smedley, P.L. \& Kinniburgh, D.G. 2002. A review of the source, behavior and distribution of arsenic in natural waters. Appl. Geochem. 17(5): 517-568.

Winkel, L.H.E., Trang, P.T.K., Lan, V.M., Stengel, C., Amini, M., Ha, N.T., Viet, P.H. \& Berg, M. 2011. Arsenic pollution of groundwater in Vietnam exacerbated by deep aquifer exploitation for more than a century. Proc. Natl. Acad. Sci. U.S.A. 108(4): 1246-1251. 


\title{
Geographical controls on arsenic variability in groundwater of Upper Indus Basin, Punjab, Pakistan
}

\author{
A. Farooqi ${ }^{1}$, N. Mushtaq ${ }^{1}$, J.A. Khattak ${ }^{1}$, I. Hussain ${ }^{1} \&$ A. van Geen ${ }^{2}$ \\ ${ }^{1}$ Environmental Geochemistry Laboratory, Faculty of Biological Sciences, Department of Environmental Sciences, \\ Quaid-i-Azam University, Islamabad, Pakistan \\ ${ }^{2}$ Lamont Doherty Earth Observatory, Columbia University, Palisades, New York, USA
}

\begin{abstract}
Blanket testing was carried out in 179 villages in Upper Indus Basin of Punjab, Pakistan. Out of total 19551 wells tested, $79 \%$ were found to have arsenic levels within WHO prescribed limit of $10 \mu \mathrm{g} \mathrm{L}^{-1}$ while $11 \%$ had arsenic levels within National limit of $50 \mu \mathrm{g} \mathrm{L}^{-1}$. Ravi flood plain was found to be comparatively more contaminated than the rest of the study area. The prevailing redox conditions for arsenic release in Punjab is found to be mixed in nature, with conditions reducing enough for Fe oxide reduction but typically not enough for complete reduction of $\mathrm{SO}_{4}$.
\end{abstract}

\section{INTRODUCTION}

Naturally occurring high arsenic (As) concentrations in groundwater of flood plains of South East and South Asia are a threat to health of more than 100 million people living there (Postma et al., 2016). The source of As in groundwater is generally associated with sediments deposited by rivers originating in Himalayas. The general geochemical conditions or settings that lead to the mobilization of arsenic into groundwater include environments that are either reducing, arid or oxidizing with elevated $\mathrm{pH}$, geothermal or sulfide mineralization (Smedley \& Kinniburgh, 2002). It is a well-known fact that distribution of As in groundwater is highly variable spatially, and varies with the geology and soil properties of the area (Winkel et al., 2011). Occurrence of high As in groundwater has also been linked to recently abandoned river channels deposits (Sahu \& Saha, 2015), with concentrations changing as hydrogeology and water table also further influence mobilization of As (Postma et al., 2016). The groundwater and surface water of Indus River system is a key source of drinking water in Pakistan. A survey carried out jointly by local government and rural development department of Pakistan, public health engineering department, and United Nations International Children's Emergency Fund (UNICEF) indicated hot spots of As abundance in Indus alluvial basin of Pakistan specifically in the central and southern region of the country. (Rabbani et al., 2017) reported 13 million people to be at risk from drinking As contaminated groundwater from 27 districts of Sindh. Keeping these in mind, blanket testing was carried out in the Punjab region to identify areas contaminated with As and pinpoint the locations of safe wells using field kits. This transboundary research also focuses on the difference in geochemical settings in both India and Pakistan responsible for As release into groundwater.

\section{METHODS/EXPERIMENTAL}

\subsection{Geological background}

Blanket testing was carried out in Upper Indus Basin, Punjab region for the testing of As and selected redox parameters. The villages covered so far were selected using Google Earth imagery along the Pakistan part of the transects (Fig. 1). The aquifer system under doabs (area between two rivers) are underlain by unconsolidated alluvial sediments deposited by Indus river tributaries during Pleistocene-Recent age. The alluvial complex has an average thickness of more than 400 meters. The sediments consist of brownish-grey, fine to medium sand, silt and clay in varying proportions with quartz, muscovite, biotite, and chlorite making up the chief mineral constituents of the sediments. The shifting course of tributaries has imparted heterogeneous nature to alluvial complex resulting in little to no vertical or lateral continuity. But still the sediments on regional scale behave as homogeneous aquifer (Farooqi et al., 2014).

\subsection{Field sampling and analysis}

Between 2015 and 2017, more than 19551 wells have been tested for As by Arsenic Econo-Quick (TM) (EQ) kit in almost 14 districts of Punjab covering 175 villages across Punjab. $\mathrm{pH} / \mathrm{EC}$ and redox sensitive parameters $\mathrm{NO}_{3}, \mathrm{SO}_{4}$, and $\mathrm{Fe}$ were also measured on field using HANNA field kits. Total of 18533 tests were performed for all 5 parameters. $10 \%$ of samples 


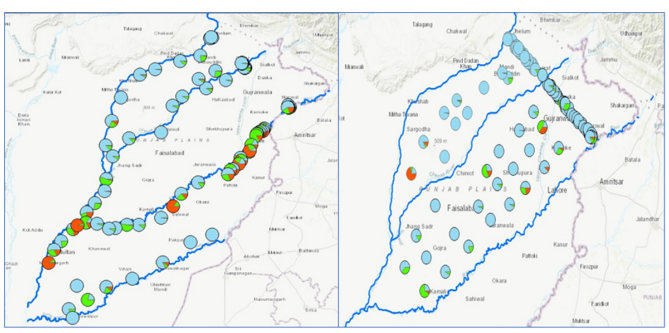

Figure 1. Distribution of arsenic in upper Indus Basin, Punjab, along Flood plains (left) and Doabs (right). The flood plain of Ravi is more affected by As contamination than Jhelum and Chenab, while northern part of the Rachna doab is comparatively more affected than Chaj doab.

were randomly collected for quality assurance for later laboratory analysis.

The sampling covered all the three-major flood plain areas of River Ravi, Chenab and Jhelum, and also covered both Rachna and Chaj Doabs.

\section{RESULTS AND DISCUSSION}

\subsection{Groundwater As distribution along Flood Plains}

Overall blanket testing results reveal that almost $79 \%$ of the wells tested had As concentration within WHO prescribed limit of $10 \mu \mathrm{g} \mathrm{L}^{-1}$ while $11 \%$ had concentrations within the National Environmental Quality Standards (NEQS) of $50 \mu \mathrm{g} \mathrm{L}^{-1}$. The testing covered major flood plains of the area and also the doabs (the area between two rivers). For better understanding of the arsenic distribution, the results are discussed separately for flood plains and doabs. $67 \%$ of the wells tested along flood plains of all three rivers (Ravi, Jhelum and Chenab) were found to be safe (As $<10 \mu \mathrm{g} \mathrm{L}^{-1}$ ) while $16 \%$ wells had As levels within the prescribed National Limit.

The comparison of proportion of wells unsafe regarding As (>WHO limit) concentrations showed Ravi flood plain to be more contaminated as compared to the Jhelum and Chenab Flood plains. $49 \%$ of the wells had As levels higher than $10 \mu \mathrm{g} \mathrm{L}^{-1} .29$ out of 34 villages tested along River Ravi had As $>50 \mathrm{ug} \mathrm{L}^{-1}$, more than that of national limit.

Along Chenab and Jhelum flood plains, only 13\% and $4 \%$ wells exceeded WHO limit, respectively.

The previously published data suggest the oxidative dissolution of As at higher $\mathrm{pH}$ to be the source of As release along Ravi river (Sultana et al., 2014).

\subsection{Arsenic in Chaj and Rachna Doabs}

Rachna Doab had comparatively higher proportion of unsafe wells (As $>10 \mu \mathrm{g} \mathrm{L}^{-1}$ ) than Chaj Doab (Fig. 1). $20 \%$ wells tested in Rachna and 2\% wells in Chaj had As levels above the prescribed WHO limit. Out of total 73 villages tested in both doabs, 10 villages had As
Table 1. Classification of redox parameters (percentage wise) on the basis of arsenic concentrations

\begin{tabular}{llll}
\hline Arsenic Classes & $\begin{array}{l}{ }^{*} \mathrm{Fe}>1 \\
\left(\mathrm{mg} \mathrm{L}^{-1}\right)\end{array}$ & $\begin{array}{l}* \mathrm{SO}_{4}>20 \\
\left(\mathrm{mg} \mathrm{L}^{-1}\right)\end{array}$ & $\begin{array}{l}* \mathrm{NO}_{3}-\mathrm{N}>10 \\
\left(\mathrm{mg} \mathrm{L}^{-1}\right)\end{array}$ \\
\hline As $\leq 10 \mu \mathrm{g} \mathrm{L}^{-1}$ & 24 & 81 & 91 \\
As $11-50 \mu \mathrm{g} \mathrm{L}^{-1}$ & 16 & 11 & 6 \\
As $>50 \mu \mathrm{g} \mathrm{L}^{-1}$ & 18 & 8 & 3 \\
\hline
\end{tabular}

*Detectable levels by Kits in $\mathrm{mg} \mathrm{L}^{-1}$

levels above $50 \mu \mathrm{g} \mathrm{L}^{-1}$. As seen from the Figure 1, the spatial distribution of As is highly variable and changes with the varying geological and topographic settings.

\subsection{Redox indicators}

Among the 11352 wells meeting the WHO prescribed limit of $10 \mu \mathrm{g} \mathrm{L}^{-1}$, only $24 \%$ samples had $\mathrm{Fe}>1 \mathrm{mg}$ $\mathrm{L}^{-1}$ and $76 \%$ samples having $\mathrm{SO}_{4}>20 \mathrm{mg} \mathrm{L}^{-1}$ detectable by kits. $\mathrm{NO}_{3}-\mathrm{N}>10 \mathrm{mg} \mathrm{L}^{-1}$ was detected in 1603 wells only using kits (Table 1). The overall redox parameter results indicate mixed conditions to be prevailing throughout study area with conditions often reducing enough for $\mathrm{Fe}$ oxide reduction but not enough for complete reduction of $\mathrm{SO}_{4}$.

\section{CONCLUSIONS}

The testing reveals wide variability in arsenic levels in groundwater with most of the samples meeting the WHO limit for drinking water in the Punjab region, Pakistan. Mixed redox settings were found to be responsible were elevated levels of As.

\section{ACKNOWLEDGEMENTS}

This project is funded by HEC-USAID under the Pak-USAID project.

\section{REFERENCES}

Postma, D., Larsen, F., Jakobsen, R., Sø, H.U. Kazmierczak, J.,Trang P.T.K., Lan, V.M., Viet, P.H., Hoan, H., Trung, D. \& Nhan, P.Q. 2016. On the spatial variation of arsenic in groundwater of the Red River floodplain, Vietnam. In: P. Bhattacharya, M. Vahter, J. Jarsjö, J. Kumpiene, A. Ahmad, C. Sparrenbom, G. Jacks, M.E. Donselaar, J. Bundschuh, \& R. Naidu (eds.) "Arsenic Research and Global Sustainability As 2016". CRC Press/Taylor and Francis (ISBN 978-1-138-02941-5), pp. 3-4.

Rabbani, U., Mahar, G., Siddique, A., \& Fatmi, Z. 2017. Risk assessment for arsenic-contaminated groundwater along River Indus in Pakistan.Environ. Geochem. Hlth. 39(1): 179-190.

Sahu, S. \& Saha, D. 2015. Role of shallow alluvial stratigraphy and Holocene geomorphology on groundwater arsenic contamination in the Middle Ganga plain, India. Environ. Earth. Sci. 73: 3523-3536. 
Smedley, P.L. \& Kinniburgh, D.G. 2002. A review of the source, behaviour and distribution of arsenic in natural waters. Appl. Geochem. 17(5): 517-568.

Sultana, J., Farooqi, A., \& Ali, U. 2014. Arsenic concentration variability, health risk assessment, and source identification using multivariate analysis in selected villages of public water system, Lahore, Pakistan. Environ. Mon Ass. 186(2): 1241-1251.
Winkel, L.H.E., Pham, T.K.T., Vi, M.L., Stengel, C., Amini, M., Nguyen, T.H., Viet, P.H. \& Berg, M. 2011. Arsenic pollution of groundwater in Vietnam exacerbated by deep aquifer exploitation for more than a century. Proc. Natl. Acad. Sci. U.S.A. 108: 1246-1251. 


\title{
The influence of irrigation-induced water table fluctuation on iron redistribution and arsenic fate in unsaturated zone
}

\author{
Z.Y. Chi, X.J. Xie, K.F. Pi \& Y.X. Wang \\ State Key Laboratory of Biogeology and Environmental Geology \& School of Environmental Studies, \\ China University of Geosciences, Wuhan, China
}

\begin{abstract}
Using high arsenic (As) groundwater as the main source of irrigation water is a common practice in vast rural regions due to the water resource shortage of surface water. This study aims to describes the As and Fe redistribution during irrigation and consequent water table fluctuation through column experiment. Results clearly demonstrate the oxygen exchange between atmosphere and column pore during both water table decrease and recovery. The exchanged oxygen has resulted in the As and Fe redistribution. Moreover, the fixed As and Fe were accumulated mostly on the top of the column during percolation. However, topsoil is precisely the site where nutrients come from for crops. As a result, As uptake by crops from soil may continually occur. Thus, it is of great significance for food security to reduce the agricultural use of high-As groundwater.
\end{abstract}

\section{INTRODUCTION}

Recent studies have shown that consumption of Ascontaminated foods became an alternative pathway for As exposed to human besides water drinking (Fransisca et al., 2015). Actually, As compounds in crops come mainly from soil and irrigation water. The As content in soil can reach up to $83 \mu \mathrm{g} \cdot \mathrm{g}^{-1}$ in some irrigated areas, which far exceeds the background level or safety level of agricultural soil (Williams et al., 2006). This poses potentially considerable risk to public health. Given above reasons, it is imperative to comprehend the As and Fe redistribution behavior during irrigation. In order to achieve the goal, a column experiment was carried out in this study. Furthermore, water table fluctuation was set to the main artificially manageable process since it has been confirmed to be a most important factor influenced the redox reactions (Tong et al., 2016).

\section{METHODS/EXPERIMENTAL}

The column experimental setup and procedure was shown in Figure 1. In this experiment, groundwater and soil was replaced by deoxidized As(III)-Fe(II) solution and acid washed quartz sand, respectively. External environment of this experiment is mainly maintained in anaerobic condition. The ventilation valve was open to atmosphere and the height of the splitter controlled the water table inside the column. The liquid samples were collected from T-value, and the flow cell was used for $\mathrm{pH}$, ORP and DO measurements. The artificially manageable process is water table fluctuations, while the vertical infiltration recharge is uninterrupted. The sand inside the column was then sampled every $6 \mathrm{~cm}$. The sampled sand was dried up under anaerobic atmosphere and then used for As and Fe sequential extraction.

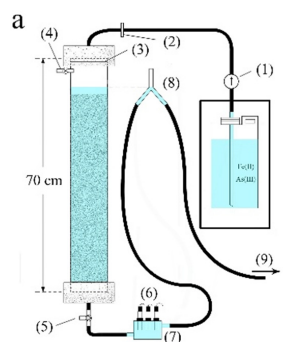

b

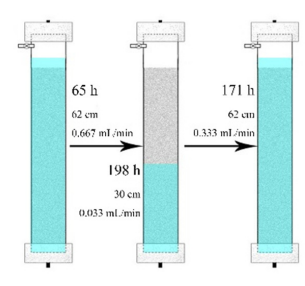

Figure 1. (a) The column experiment setup. (1) Peristaltic pump, (2) Syringe-driven filter, (3) Water distributor, (4) Ventilation valve, (5) T valve, (6) Detector probe, (7) Small flow cell, (8) 3-way splitter, (9) Waste. (b) The experimental procedure.

\section{RESULTS AND DISCUSSION}

\subsection{Water table fluctuation and oxygen transfer}

As shown in Figue 2a, during the equilibrium phase ( $0-65 \mathrm{~h})$, oxygen inside the column was washed away, and thus effluent dissolved oxygen content reached the lowest level at $65 \mathrm{~h}$. Then, effluent DO rose rapidly when valve was opened and water table lowered down to $30 \mathrm{~cm}$. This indicates that the decrease of water table can result in the infiltration of air into column pore. Effluent DO then decreased due to consumption of dissolved oxygen. Notably, the experimental results showed that oxygen exchange between atmosphere and column pore also happened during the period of water table recovery. The effluent DO showed a sharp rise when water table ascended, and the DO remained at about $6.7 \mathrm{mg} \cdot \mathrm{L}^{-1}$ for a long time after recovery. This demonstrates that atmospheric oxygen was trapped by solution before the injected solution flowed into sand pores. 

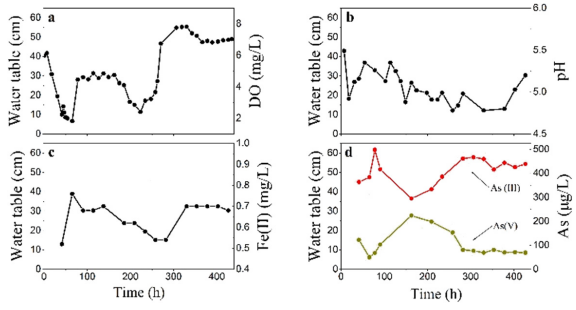

Figure 2. Effluent monitoring results.

\subsection{The As(III) and Fe(II) oxidation}

As shown in Figure 2c, it is a synchronous variation in $\mathrm{DO}$ and $\mathrm{Fe}(\mathrm{II})$ contents at the beginning of LWP, which illustrates that DO initiates Fe(II) oxidation. The effluent $\mathrm{pH}$ and $\mathrm{Fe}(\mathrm{II})$ content showed the same varying trend (Fig. 2b), which indicates the Fe(III) hydrolysis controlled the aqueous-phase $\mathrm{pH}$ in this experiment. However, the $\mathrm{Fe}$ (II) and DO content varying trends were not completely the opposite. Especially at the latter half of LWP, the effluent $\mathrm{Fe}(\mathrm{II})$ content and DO, solution $\mathrm{pH}$ consistently decreased. This may result from the self-catalyzed characteristic of Fe(II) oxidation in the presence of $\mathrm{Fe}$ (III) mineral.

Moreover, As(III) was observed to be partially oxidized during percolation (Fig. 2d). However, it has been confirmed that As(III) oxidation is quite slow in the absence of strong oxidant. The two processes that can accelerate As(III) oxidation under natural conditions are microbial mediation and hydroxyl radical-evolving function. Jia et al. has confirmed the production of hydroxyl radical when $\mathrm{Fe}(\mathrm{II})$ was oxidized by $\mathrm{O}_{2}$ (Jia et al., 2017). Thus, the mechanism promoting the As(III) oxidation was considered as the generation of hydroxyl radical when the $\mathrm{Fe}(\mathrm{II})$ was oxidized to Fe(III) during this column experiment.

\subsection{As and Fe redistribution}

The As and Fe extraction results are shown in Figure 3. It is obvious that both As and Fe contents were higher in the sands of top $9 \mathrm{~cm}$, but decreased dramatically with depth increased. The As extraction results showed that the As in each sample mainly existed as the form of adsorbed As (especially strongly adsorbed As), accounting for $58.0 \%-88.0 \%$ with an average of $76.8 \%$ of total solid-phase As. Furthermore, the proportion of weakly adsorbed As was gradually increased with depth, while strongly adsorbed and non-adsorbed As decreased. This was likely due to the transformation from As-Fe surface complexation into As-Fe surface precipitation during the growth of $\mathrm{Fe}$ (III) mineral at the top of column.

\subsection{Environmental implications}

The As/Fe molar ratios ranged from 0.025 to 0.048 with an average of 0.035 , which far exceeded the background level of soils. These fixed As were more likely to be released again due to the transformation

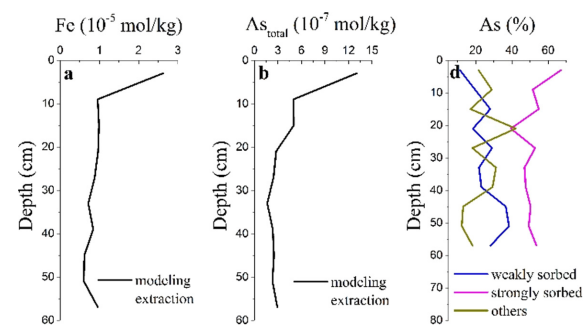

Figure 3. The results of As, Fe extraction.

of $\mathrm{Fe}$ (III) mineral or microbial actions after irrigation. This release could be very slow and last for a long time. Coincidentally, topsoil is precisely where nutrients come from for crops. Thus, irrigation and consequent water table fluctuation may pose a long-term potential risk to public health via dietary approach.

\section{CONCLUSIONS}

The column experiment results show that irrigation and consequent water table fluctuations (both decrease and increase) can result in the oxygen exchange between atmosphere and column pore. The exchanged oxygen was then initiated the Fe(II) and As(III) oxidation. As a results, As and Fe was accumulated on the sand column, especially top of column. These processes are highly likely to cause a long-term potential risk to public health via dietary approach. Thus, it is of great significance to reduce the agricultural use of high-As groundwater.

\section{ACKNOWLEDGEMENTS}

This study was jointly supported by the Natural Science Foundation of China (Nos: 41372254, 41772255 and 41521001) and Hubei Science and Technology Innovation Project (2016ACA167).

\section{REFERENCES}

Fransisca, Y., Small, D.M., Morrison, P.D., Spencer, M.J.S., Ball, A.S. \& Jones, O.A.H. 2015. Assessment of arsenic in Australian grown and imported rice varieties on sale in Australia and potential links with irrigation practises and soil geochemistry. Chemosphere 138: 1008-1013.

Jia, M., Bian, X. \& Yuan, S. 2017. Production of hydroxyl radicals from $\mathrm{Fe}(\mathrm{II})$ oxygenation induced by groundwater table fluctuations in a sand column. Sci. Total Environ. 584: 41-47.

Tong, M., Yuan, S., Ma, S., Jin, M., Liu, D., Cheng, D., Liu X., Gan, Y. \& Wang, Y. 2016. Production of abundant hydroxyl radicals from oxygenation of subsurface sediments. Environ. Sci. Technol. 50: 214-221.

Williams, P.N., Islam, M.R., Adomako, E.E., Raab, A., Hossain, S.A., Zhu, Y.G., Feldmann, J. \& Meharg, A.A. 2006. Increase in rice grain arsenic for regions of Bangladesh irrigating paddies with elevated arsenic in groundwaters. Environ. Sci. Technol. 40: 4903-4908. 


\title{
Towards imaging the spatial distribution of geochemical heterogeneities and arsenic sources
}

\author{
M. Rolle ${ }^{1,2}$, M. Battistel ${ }^{1}$, F. Onses ${ }^{1}$, R. Mortensen ${ }^{2}$, S. Fakhreddine ${ }^{3}$, S. Fendorf ${ }^{3}$, \\ P.K. Kitanidis ${ }^{3}$ \& J.H. Lee Le $^{3,4}$ \\ ${ }^{1}$ Department of Environmental Engineering, Technical University of Denmark, Kongens Lyngby, Denmark \\ ${ }^{2}$ SDC University, Beijing, China \\ ${ }^{3}$ Department of Civil and Environmental Engineering, Stanford University, Stanford, CA, USA \\ ${ }^{4}$ Department of Environmental Engineering, University of Hawaii, Honolulu, HA, USA
}

\begin{abstract}
We propose a methodology to image the spatial distribution of reactive minerals in the subsurface based on distributed sensor measurements of water quality parameters coupled with forward and inverse reactive transport modeling. We focus on kinetic oxidative dissolution of pyrite and As-bearing pyrite minerals and illustrate the potential of the methodology in synthetic modeling applications at different scales, as well as in laboratory flow-through experiments in 1-D column setups and 2-D flow-through chambers.
\end{abstract}

\section{INTRODUCTION}

The spatial distribution of physical and chemical heterogeneities is critical in many subsurface applications. For instance, the location of reactive minerals is a primary factor controlling the fate and transport of organic and inorganic pollutants in groundwater. The latter include geogenic contamination causing the release of heavy metals and metalloids such as arsenic. A number of studies have focused on using hydrologic measurements and inverse modeling techniques to image physical heterogeneity and the spatial distribution of hydraulic conductivity. However, the applications of such approaches to water quality and reactive transport problems are rare.

In this study we focus on oxidation of pyrite and As-bearing pyrite. This process is of key importance in many natural settings as well as in engineering applications such as managed aquifer recharge.

\section{METHODS}

\subsection{Flow-through experiments}

We studied the oxidative dissolution of pyrite in different experimental setups, including batch systems, 1-D column setups and 2-D flow-through chambers. Measurements of water quality parameters such as $\mathrm{pH}$, dissolved oxygen, iron and sulfur were useful to formulate and constrain pyrite dissolution kinetics. In particular, spatially-distributed measurements of dissolved oxygen in the 1-D and 2-D setups were instrumental for imaging pyrite inclusions. Non-invasive optode sensors along the column setups and at different cross sections in the 2-D system allowed us to measure oxygen transport and consumption at high spatial (a) True Pyrite Distribution

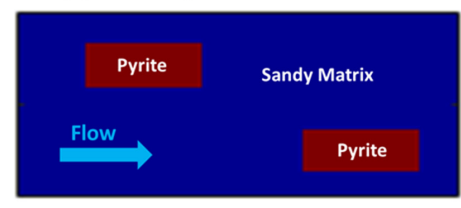

(b) Oxygen Concentration

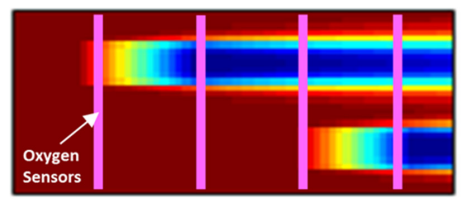

(c) Estimated Pyrite Distribution

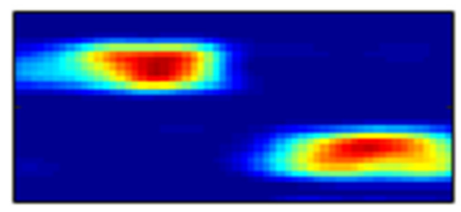

Figure 1. Schematic illustration of the 2-D experimental setup with two pyrite inclusions (a), location of distributed sensor measurements (b), and results of the inverse reactive transport simulations (c).

resolution (2.5 $\mathrm{mm}$ spacing). A schematic illustration of the experimental setup with two pyrite inclusions is provided in Figure 1.

\subsection{Reactive transport modeling}

A reactive transport network, including the kinetics of pyrite and As-bearing pyrite oxidative dissolution, 
(a) True Pyrite Distribution

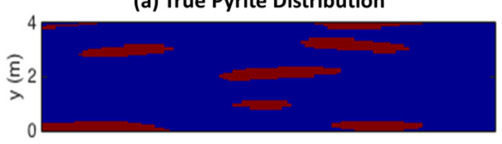

(b) Best estimate with $\mathbf{1 0 \%}$ error

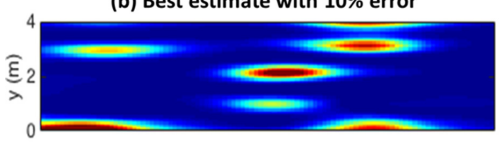

(c) Best estimate with $\mathbf{2 0 \%}$ error

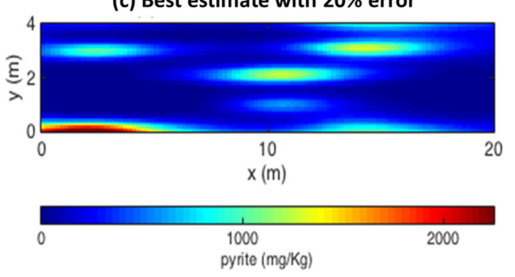

Figure 2. Maps of randomly distributed As-bearing pyrite: true distribution (a) and best estimate in case of $10 \%$ error (b) and 20\% error (c) in DO measurement (modified from Fakhreddine et al., 2016).

was implemented in PHT3D that served as the forward reactive transport simulator. The forward model was applied for synthetic simulations at different scales as well as to quantitatively interpret the laboratory results.

As inverse model, we used the Principal Component Geostatistical Approach (PCGA, Kitanidis and Lee, 2014) to determine the spatial distribution of pyrite and As-bearing pyrite. The PCGA approach was used in combination with the developed forward model and with a limited number of dissolved oxygen observations.

\section{RESULTS AND DISCUSSION}

The results of the laboratory experiments performed in a number of columns with different size, concentration and number of pyrite inclusions, as well as the outcomes of the 2-D flow-through experiments are presented by Battistel et al. (2017). Here we show some of the results of the synthetic applications at the field scale. Figure 2a shows a 2-D cross section of a shallow aquifer with randomly distributed inclusions of Asbearing pyrite. The inversion was based on synthetic oxygen data, mimicking measurements in multilevel observation wells with $4 \mathrm{~m}$ spacing along the flow path. The results show the capability of the approach to correctly locate the As-bearing pyrite inclusions as well as their concentration. The outcomes show a good performance of the inversion also in presence of significant measurement errors (Fig. 2b and 2c).

Figure 3 shows the outcomes of simulations performed in the true geochemically heterogeneous aquifer as well as in the best estimate fields obtained with the proposed inverse method. The inverse results

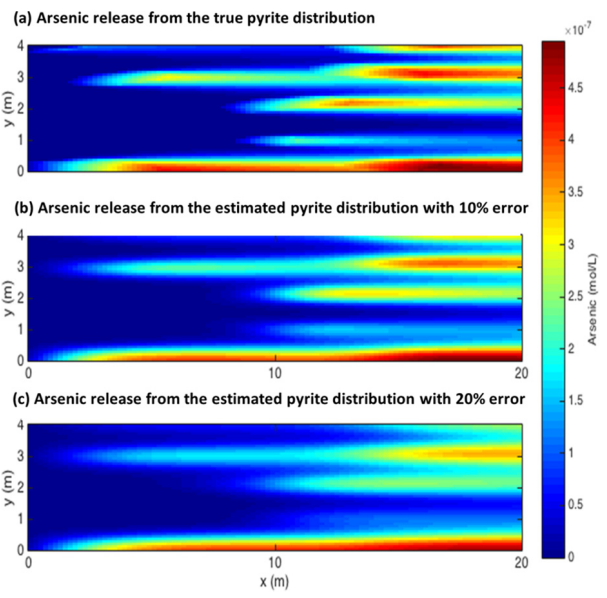

Figure 3. Arsenic plumes in the geochemically heterogeneous aquifers for the true As-bearing pyrite distribution (a), and for the best estimates (b and c) obtained with the proposed inverse modeling approach (reprinted from Fakhreddine et al., 2016, with permission from Elsevier).

show the capability to reproduce the multiple plumes of dissolved arsenic in the heterogeneous domain. An increase in the oxygen measurement error still allows representing the main arsenic plumes, however, the small scale As-sources were more difficult to capture.

\section{CONCLUSIONS}

We proposed an inverse method for tomography of geochemical heterogeneity. The investigation was focused on imaging the spatial distribution of pyrite and As-bearing pyrite based on spatially distributed oxygen measurements. The methodology proposed is flexible and can be extended to different processes, reactive minerals, as well as distributed measurements of other water quality parameters.

\section{ACKNOWLEDGEMENTS}

This study was supported by a grant from the Villum Foundation and by the Sino-Danish Center.

\section{REFERENCES}

Battistel, M., Lee, J., Onses, F., Mortensen, R. \& Rolle, M. 2017. Imaging the spatial distribution of pyrite in porous media: multidimensional flow-through experiments and inverse modeling (in preparation).

Fakhreddine, S., Lee, J., Kitanidis, P.K., Fendorf, S. \& Rolle, M. 2016. Imaging geochemical heterogeneity using inverse reactive transport modeling: An example for characterizing arsenic mobility and distribution. Adv. Water Res. 88: 186-197.

Kitanidis, P.K \& Lee, J. 2014. Principal component geostatistical approach for large-dimensional inverse problems. Water Resour. Res. 50, 5428-5443. 


\title{
Source of arsenic bearing detrital minerals in shallow aquifer of southeastern Bangladesh
}

\author{
A.H.M. Selim Reza ${ }^{1} \&$ H. Masuda ${ }^{2}$ \\ ${ }^{1}$ Department of Geology and Mining, University of Rajshahi, Rajshahi, Bangladesh \\ ${ }^{2}$ Department of Biology and Geosciences, Osaka City University, Sumiyoshi-ku, Japan
}

\begin{abstract}
Forty seven (47) sediment samples from two bore holes from different depths and two river bed sediments from Meghna River were collected from arsenic hot spot area of Bangladesh for geochemical analyses. Concentrations of major elements $\left(\mathrm{SiO}_{2}, \mathrm{CaO}, \mathrm{MgO}, \mathrm{K}_{2} \mathrm{O}, \mathrm{Na}_{2} \mathrm{O}, \mathrm{Fe}_{2} \mathrm{O}_{3}, \mathrm{Al}_{2} \mathrm{O}_{3}, \mathrm{Mno}, \mathrm{TiO}_{2}\right)$ and trace elements (V, Cr, Co, Ni, Cu, Zn, Rb, Sr, Y, Zr, Nb, Ba, La, Ce, Nd, Th and Pb) of sediment were analyzed by XRF (X-ray Fluorescence Spectrometer). Total As of bulk sediment was measured by ICP-MS. Total As content in sediment ranges from $1.91 \mathrm{mg} \mathrm{kg}^{-1}$ to $7.97 \mathrm{mg} \mathrm{kg}^{-1}$ (average $3.60 \pm 2.04 \mathrm{mg} \mathrm{kg}^{-1}$ ). Higher content of As $\left(7.97 \mathrm{mg} \mathrm{kg}^{-1}\right.$ ) is observed in clayey sediment and lower content $\left(1.91 \mathrm{mg} \mathrm{kg}^{-1}\right)$ is found in sandy sediments. The river bed sediment contains arsenic ranges from $1.65 \mathrm{mg} \mathrm{kg}^{-1}$ to $2.27 \mathrm{mg} \mathrm{kg}^{-1}$. The sequential extraction of arsenic along with the strong positive correlation between As, Fe and Mn suggest that As is adsorbed by $\mathrm{FeOOH} / \mathrm{MnOOH}$ and liberated from sediment into groundwater due to reductive dissolution of $\mathrm{FeOOH}$ and $\mathrm{MnOOH}$. The bulk mineralogy of the sediments was determined by X-ray powder diffraction (XRD) method, which shows that quartz, feldspar, mica and chlorite are dominant mineral in sediment of the study area. The positive correlation between As and intensity of mica and chlorite mineral also reveals that the possible source of As in sediment are mica and clay minerals.
\end{abstract}

\section{INTRODUCTION}

Arsenic (As) contamination of groundwater of Bangladesh is one of the greatest environmental disasters in the world especially in the southeastern part of Bangladesh (Ahmed et al., 2004; von Brömssen et al., 2007). About 10 million people in Bangladesh are facing various diseases from drinking of arsenic contaminated groundwater. Ganges, Brahmaputra and Meghna carry huge amount of sediment with arsenic rich iron oxides mineral and deposited in the south eastern part of Bangladesh (Seddique et al., 2008). There are several hypotheses regarding the release mechanism of arsenic in groundwater. One of the well established hypotheses is the reductive dissolution of iron oxyhydroxides or manganese oxyhydroxides in presence of organic matter by anaerobic bacteria release arsenic from sediment into groundwater under reducing condition. Few studies have been carried out regarding the source and mobilization of arsenic in the south eastern part of Bangladesh especially in Chandpur district.

\section{METHODS/EXPERIMENTAL}

\subsection{Samples collection in the field}

Forty seven (47) sediment samples from two bore holes using hand percussion method at different depths from Hajiganj areas of Chandpur district and two river bed sediments were collected from Meghna river of Chandpur districts in April 2015.

\subsection{Samples analyses in the laboratory}

The bulk mineralogy of the sediments was determined by X-ray powder diffraction (XRD) using a Rigaku Geigerflex instrument (RAD-IA system) with Nifiltered $\mathrm{Cu} \mathrm{Ka}$ radiation $(30 \mathrm{kV}, 10 \mathrm{~mA})$ operating in step scan mode, over an angular range of $2-65^{\circ} 2 \theta$ with $0.02^{\circ} 2 \theta$ steps and 2 -scount time on $200 \mathrm{mg}$ unoriented side-packed powder mounts. Prior to analysis, $1 \mathrm{~g} \mathrm{sam}-$ ples, $<63 \mathrm{~lm}$ particles passing through $230 \mathrm{mesh}$, from bulk dried sediments, were ground by hand with a mortar. Approximate relative abundance ratios of major minerals were estimated from the relative intensities of the most intense and specified peak of each mineral. The analytical and sampling-related error in determining mineral abundance was about $\pm 5 \%$.

The major element composition of bulk dried and powdered sediments were determined by X-ray fluorescence (VXQ-160S, Shimadzu) using glass bead samples, which were prepared by fusion of sediment samples with lithium borate (1:3 ratio). Calibration lines were obtained using glass beads made by the same procedure with reference sedimentary rock samples (sedimentary rock series, JSd-1, JSd-2, JSd-3, JSI-1 and JLk-1; Geological Survey of Japan). Analytical error for major elements was within $\pm 3 \%$, estimated using the duplicate standard samples.

Total As concentration of bulk sediment was determined by ICP-MS (ICP-MS; SPQ 9900) using calibration lines made with commercially distributing standard and spike solutions (WAKO Lmt., Japan). Analytical error is $<7 \%$ for As elements. BCR method was applied for sequential extraction of As. 


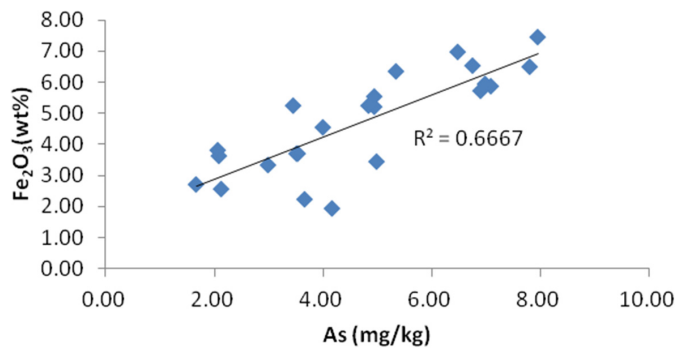

Figure 1. As vs $\mathrm{Fe}_{2} \mathrm{O}_{3}$ in the drilling site 1.

\section{RESULTS AND DISCUSSION}

\subsection{Chemical properties of the sediment samples}

Based on XRD analysis, abundant quartz, mica (muscovite and biotite), feldspar (both K-feldspar and plagioclase), and chlorite were observed in both sandy and silty clay sediments. In southeastern Bangladesh, sediments are rich in quartz, mica, feldspar and chlorite (Anawar et al., 2003). The aquifer sediments become gray when the reduction of Fe (oxy) hydroxides is complete and the majority load of sorbed As is released to solution. The depth profile relationships of arsenic with iron, manganese and aluminum oxides and the correlations among these variables suggest that arsenic is strongly associated with iron and manganese oxides and noncrystalline aluminosilicate phases. The correlation analyses (Fig. 1) revealed that the concentrations of As in the sediments are well correlated with those of $\mathrm{Fe}, \mathrm{Mn}$ and $\mathrm{Al}$ contents $\left(\mathrm{R}^{2}=0.666, \mathrm{p}<0.05\right.$ for $\mathrm{Fe}_{2} \mathrm{O}_{3} \mathrm{R}^{2}=0.66, \mathrm{p}<0.05$ for $\mathrm{MnO} ; \mathrm{R}^{2}=0.666$, $\mathrm{p}<0.05$ for $\mathrm{Al}_{2} \mathrm{O}_{3}$ ) in the drilling site 1 .

\subsection{Mineralogical and geochemical composition of sediments}

Positive correlation of As and $\mathrm{Fe}_{2} \mathrm{O}_{3}\left(\mathrm{R}^{2}=0.666\right.$, $\mathrm{p}<0.05$ ) observed in the core sediments of Chandpur is consistent with the previous reports by Nickson et al. (2000) for the Ganges flood plain sediments, Bangladesh. Ahmed et al. (2004) and Hasan et al. (2007) also reported that $\mathrm{Fe}$ oxyhydroxides are the major hosts of As in the Ganges delta plain sediments.

\subsection{Hydrogeochemical factors controlling arsenic mobilization}

Sequential extraction method suggests that $\mathrm{Fe}_{2} \mathrm{O}_{3}$ or $\mathrm{MnO}$ phase act as a scavenger of As in sediment (Table 1). A strong positive correlation between As and total $\mathrm{Fe}$ (denoted by $\mathrm{Fe}_{2} \mathrm{O}_{3}$ ) is observed throughout the sediment column (Fig. 1). Although sediments of the clay unit contain the greatest amounts of $\mathrm{Fe}_{2} \mathrm{O}_{3}$ (6.96-7.45 wt.\%), probably due to enrichment of claysize chlorite, a correlation with As is observed (Fig. 1). The total As content shows a positive relationship with the XRD intensity of mica and chlorite in both core sediment samples (Seddique et al., 2011).
Table 1. Sequentially extracted As from sediment using BCR method.

\begin{tabular}{llllll}
\hline & $\begin{array}{l}\text { Acid } \\
\text { soluble } \\
\text { spm }\end{array}$ & $\begin{array}{l}\text { Reducible } \\
\text { ppm }\end{array}$ & $\begin{array}{l}\text { Oxidizable } \\
\text { ppm }\end{array}$ & $\begin{array}{l}\text { Insoluble } \\
\text { ppm }\end{array}$ & $\begin{array}{l}\text { Residue } \\
\text { ppm }\end{array}$ \\
\hline D1-10 & 0.33 & 0.22 & 0.62 & 3.82 & 0.49 \\
D1-20 & 0.13 & 0.44 & 0.82 & 2.08 & 0.00 \\
D1-30 & 0.16 & 0.25 & 0.84 & 1.77 & 0.00 \\
D1-40 & 0.13 & 0.47 & 0.76 & 1.49 & 0.00 \\
D1-50 & 0.28 & 1.30 & 0.89 & 5.41 & 0.59 \\
D1-60 & 0.14 & 0.39 & 0.49 & 0.90 & 0.00 \\
D1-70 & 0.31 & 1.13 & 0.93 & 2.55 & 0.29 \\
D1-80 & 0.20 & 0.68 & 0.91 & 1.01 & 0.20 \\
D1-90 & 0.20 & 0.30 & 0.42 & 0.52 & 0.15 \\
D1-100 & 0.07 & 0.93 & 1.37 & 3.87 & 0.51 \\
D1-110 & 0.34 & 1.08 & 0.84 & 4.08 & 0.51 \\
D1-120 & 0.28 & 0.89 & 0.52 & 3.19 & 0.53 \\
\hline
\end{tabular}

\section{CONCLUSIONS}

Positive correlations among As, $\mathrm{MnO}$, and $\mathrm{Fe}_{2} \mathrm{O}_{3}$ suggest that reductive dissolution of $\mathrm{MnOOH}$ and $\mathrm{FeOOH}$ mediated by anaerobic bacteria represents an important mechanism for releasing arsenic into the groundwater. $\mathrm{Fe}$ and $\mathrm{Mn}$ oxides may be the possible host of As in sediment of Bengal basin. The positive correlation between As and intensity of mica and chlorite mineral also reveals that the possible source of As in sediment are mica and clay minerals.

\section{ACKNOWLEDGEMENTS}

The authors are grateful to JSPS for financial support.

\section{REFERENCES}

Ahmed, K.M., Bhattacharya, P., Hasan, M.A., Akhter, S.H., Alam, S.M.M., Bhuyian, M.A.H., Imam, M.B., Khan, A.A. \& Sracek, O. 2004. Arsenic contamination in groundwater of alluvial aquifers in Bangladesh: An overview. Appl. Geochem. 19(2): 181-200.

Anawar, H.M., Akai, J., Komaki, K., Terao, H., Yoshioka, T., Ishizuka, T., Safiullah, S. \& Kato, K. 2003. Geochemical occurrence of arsenic in groundwater of Bangladesh: sources and mobilization processes. J. Geochem. Explor. 77(2): 109-131.

Hasan, M. A., Ahmed, K. M., Sracek, O., Bhattacharya, P., von Brömssen, M., Broms, S., Fogelström, J., Mazumder, M.L. \& Jacks, G. 2007. Arsenic in shallow groundwater of Bangladesh: investigations from three different physiographic settings. Hydrogeol. Jour. 15: 1507-1522.

Nickson, R.T., McArthur, J.M., Ravenscroft, P. Burgess, W.G. \& Ahmed, K.M. 2000. Mechanism of arsenic release to groundwater, Bangladesh and West Bengal. Appl. Geochem. 15: 403-413.

Seddique, A.A., Masuda, H., Mitamura, M., Shinoda, K., Yamanaka, T., Itai, T., Maruoka, T., Uesugi, K., Ahmed, K.M. \& Biswas, D.K. 2008. Arsenic release from biotite into a Holocene groundwater aquifer in Bangladesh. Appl. Geochem. 23(8): 2236-2248.

von Brömssen, M., Jakariya, Md., Bhattacharya, P., Ahmed, K. M., Hasan, M.A., Sracek, O., Jonsson, L., Lundell, L. \& Jacks G. 2007. Targeting low-arsenic aquifers in groundwater of Matlab Upazila, Southeastern Bangladesh. Sci. Total Environ. 379: 121-132. 


\title{
Groundwater arsenic contamination in selected area of Bihar
}

\author{
S. Kumari ${ }^{1}$, A.K. Ghosh ${ }^{2}$, D. Mondal ${ }^{3}$, S. Suman ${ }^{4}$, P. Sharma ${ }^{4}$, P. Kumari ${ }^{2}$, N. Bose ${ }^{4}$ \& S.K. Singh ${ }^{4}$ \\ ${ }^{1}$ B.R.A. Bihar University, Muzaffarpur, Bihar, India \\ ${ }^{2}$ Mahavir Cancer Institute and Research Center, Patna, India \\ ${ }^{3}$ School of Environment \& Life Sciences, University of Salford, Salford, UK \\ ${ }^{4}$ Department of Geography, A.N. College, Patna, India
}

\begin{abstract}
Arsenic (As) is more concentrated near river plain of Bihar, like Ganga and Gandak rivers. It is not reported in places where fluoride content is high in ground water. The current study observed high As contents in the alluvial aquifer of Ganga basin, but no As in hard rock area away from Ganga like Banka district of Bihar.
\end{abstract}

\section{INTRODUCTION}

Arsenic (As) is an element, which is highly toxic in nature. The occurrence of As in ground water was first reported in 1980 in West Bengal in India. Groundwater is the main source of drinking water and constitutes about more than $80 \%$ drinking source in rural Bihar. The groundwater As contamination in Bihar was first reported in Semaria Ojha Patti village of Shahpur, a block of Bhojpur district in 2002 (Chakraborti et al., 2003). So far, 17 of 37 districts and a total of 87 of 532 community blocks have been investigated for groundwater As contamination. Three community blocks were As safe, as all the sources tested in these blocks had As levels below the detection limit of the measurement method used (Ghosh et al., 2009). Currently, the groundwater As contamination has spread to 16 districts, threatening more than 10 million people in Bihar (Ghosh et al., 2007). Out of a total 240,000 water supply hand pumps (public and private) in As affected blocks of Bihar, only $27 \%(66,623)$ of the sources were tested for elevated As levels (Nickson et al., 2007). The continuous consumption of As through drinking water and food sources may lead to As poisoning popularly known as 'Arsenicosis'. The United States National Research Council has reported that, one in 10 people who drink water containing $500 \mu \mathrm{g} \mathrm{L}^{-1}$ of As may ultimately develop lung, bladder, and skin cancers. Arsenic health effects range from skin lesions to cancer at values from $10 \mu \mathrm{g} \mathrm{L}^{-1}$ to up to $2000 \mu \mathrm{g} \mathrm{L}^{-1}$ of As in drinking water.

\section{METHODS}

\subsection{Study area}

Samples $(\mathrm{N}=42)$ were collected from volunteers residing in As contaminated areas from Bhagalpur (Rannuchak and Nandgola), Banka (Rajpura and Kakna), Saran (Sabalpur), Patna (Haldi Chapara,
Maner) and Samastipur (hanssopur) districts of Bihar, India as a part of ongoing Nutri-SAM project.

\subsection{Data collection}

After taking informed consent, data on socioeconomic, nutritional and health status were collected using questionnaire. Water sample were collected and As content was estimated by Atomic Absorption Spectrophotometer (PerkinElmer PinAAcle 900 T) using standard APHA protocol.

\subsection{Analysis method of water}

Sterilized bottles were used for collection of water sample in which 6-10 drops of $1 \% \mathrm{HNO}_{3}$ was added as preservative in each sample bottle. Water samples were collected after 10-15 minutes of flushing the hand pump. Sample bottle were filled up to neck. Samples were brought to lab and stored in refrigerator at $5^{\circ} \mathrm{C}$. Arsenic content was analyzed by AAS.

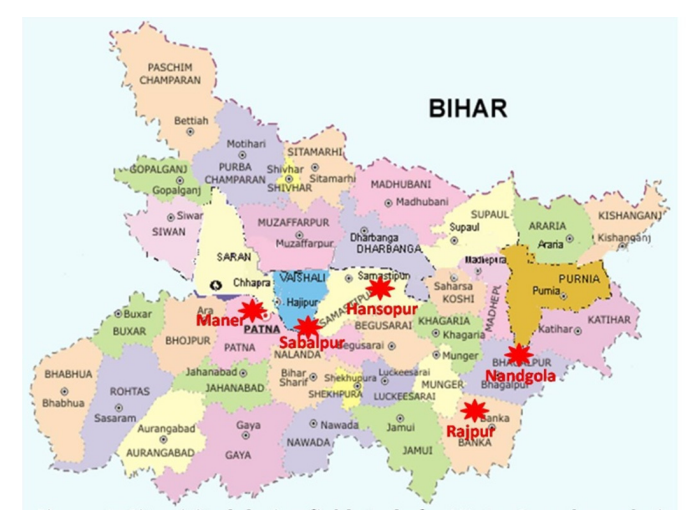

Figure 1. Site visited during field study for water sample analysis. 


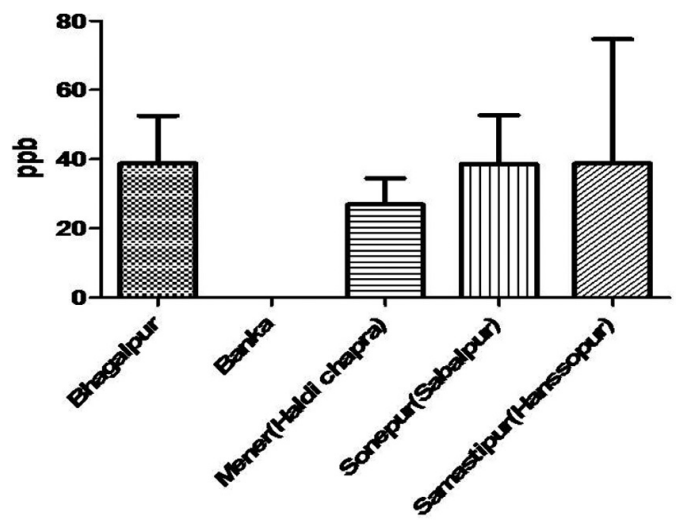

Figure 2. Arsenic level in water samples.

Table 1. Summary of arsenic concentrations $\left(\mu \mathrm{g} \mathrm{L}^{-1}\right)$.

\begin{tabular}{llcl}
\hline Area & Mean & SEM & Maximum \\
\hline Bhagalpur & 38.79 & 13.75 & 99.47 \\
Banka & 00 & 00 & 00 \\
Mener (Haldi Chapra) & 26.88 & 7.527 & 50.62 \\
Sonepur (Sabalpur) & 38.62 & 14.09 & 107.1 \\
Samastipur (Hanssopur) & 38.74 & 35.96 & 254.5 \\
\hline
\end{tabular}

\subsection{Statistical analysis}

Descriptive data as mean \pm standard deviation along with comparison tests, association and correlations represented using Graph Pad Prism was done.

\section{RESULTS AND DISCUSSION}

\subsection{Arsenic level in water samples}

There were significant differences between As level in water of different study site. Mean \pm SEM of As level in Bhagalpur was $38.79 \pm 13.75 \mu \mathrm{g} \mathrm{L}^{-1}(\mathrm{n}=11)$, mean \pm SEM of As level in Maner (Haldi Chapra) was $26.88 \pm 7.53 \mu \mathrm{g} \mathrm{L}^{-1}(\mathrm{n}=7)$, mean \pm SEM of As level in Sonepur (Sabalpur) was 38.62 $\pm 14.09 \mu \mathrm{g}$ $\mathrm{L}^{-1}(\mathrm{n}=8)$, mean \pm SEM of As level in Samastipur (Hanssopur) was $38.74 \pm 35.96 \mu \mathrm{g} \mathrm{L}^{-1}(\mathrm{n}=7)$.

High As concentration was observed at 50 to $140 \mathrm{ft}$ depth, while groundwater samples below $250 \mathrm{ft}$ had no As in this area. There was no significant difference in demography and nutrient intake between participants. Skin pigmentation and keratosis were reported in low socioeconomic people residing in these areas, while with high socio economic status have little or no symptoms, which indicates that nutritional supplement has a great role in detoxification of As toxicity.

\section{CONCLUSIONS}

It is concluded from study that As is more concentrated near river plain of Bihar, like Ganga and Gandak rivers. It is not reported in places where high fluoride content is reported for example Banka district but has no As.

\section{ACKNOWLEDGEMENTS}

This study is funded by the DST-UKIERI Thematic partnership project. We thank all the participants.

\section{REFERENCES}

Chakraborti, D., Mukherjee, S.C., Pati, S., Sengupta, M.K., Rahman, M.M. \& Chowdhury, U.K. 2003. Arsenic groundwater contamination in middle Ganga plain, Bihar, India: A future danger. Environ. Health Persp. 111(9): 1194-201.

Ghosh, A.K., Singh, S.K., Bose, N., Roy, N.P., Singh, S.K., Upadhyay, A.K., Kumar, S. \& Singh A. 2009. Arsenic hot spots detected in the state of Bihar (India): A serious health hazard for estimated human population of 5.5 lakhs. In Assessment of Ground Water Resources and Management, I.K. International Publishing House Pvt. Ltd., New Delhi, India., 62-70.

Ghosh, A. K., Singh, S.K., Bose, N., Singh, S.K., Singh, A., Chaudhary, S. Mishra, R., Roy, N.P. \& Upadhyaya, A. 2007. Study of arsenic contamination in ground water of Bihar (India) along the river Ganges. In: International Workshop on Arsenic Sourcing and Mobilization in Holocene Deltas. Department of Science and Technology, Government of India, pp. 83-87.

Nickson, R., Sengupta, C., Mitra, P., Dave, S.N., Banerjee, A. K., Bhattacharya, A., Basu, S., Kakoti, N., Moorthy, N. S., Wasuja, M., Kumar, M., Mishra, D.S., Ghosh, A., Vaish, D. P., Srivastava, A. K., Tripathi, R. M., Singh, S. N., Prasad, R., Bhattacharya, S. \& Deverill, P. 2007. Current knowledge on the distribution of arsenic in groundwater in five states of India. J. Environ. Sci. Heal. A, 42(12): 1707-1718. 


\title{
Naturally occurring arsenic in geothermal systems in Turkey
}

\author{
A. Baba \\ Izmir Institute of Technology, Geothermal Energy Research and Application Center, Izmir, Turkey
}

\begin{abstract}
Human beings have been benefiting from geothermal energy for different uses since the dawn of the civilization in many parts of the world. One of the earliest uses of geothermal energy was for heating and was used extensively by Romans in Turkey, where is an area of complex geology with active tectonics and high geothermal potential. The highest concentrations of naturally occurring aqueous arsenic (As) are found in certain types of geothermal waters, which are generally related to faults and alteration zone. The especially volcanic activity led to the delineation of wide-ranging areas of alteration within mineral assemblages, from advanced argillic type to silica type to prophylitic type at deep levels. The advanced argillic alteration zones are typified by enrichment of sulfur in volcanic rocks that have been dominant in the geological formation of Turkey and the primary mechanism for the presence of numerous trace elements in earth's crust, including but not limited to arsenic. Also, secondary epithermal gypsum has a high concentration of As in the form of realgar and orpiment along the fracture zones of metamorphic and carbonate aquifers. The temperature of geothermal fluid ranges from 40 to $295^{\circ} \mathrm{C}$ in Turkey. The high arsenic concentrations in geothermal resources have been detected in different part of Turkey from 1 to $6000 \mu \mathrm{g} \mathrm{L}^{-1}$ in geothermal fluids.
\end{abstract}

\section{INTRODUCTION}

Plate tectonics control the thermal conditions in the crust. These large-scale movements of plates produce geothermal systems in different part of the world. For example, geothermal systems in Turkey located in the active Alpine-Himalayan Fold and Thrust Belt where the collision of African and Eurasian plates and also the closure of the Tethys Ocean occurs today (Bozkurt, 2001). The graben systems and major faults accompanied by young volcanism form abundant geothermal areas in tectonically-active in most part of Turkey. Generally, geothermal field in Turkey roughly parallel the trends of the graben-bounding faults, young volcanism and hydrothermally altered areas (Mutlu \& Gülec, 1998; Simsek et al., 2002; Baba \& Ármannsson, 2006; Baba \& Sözbilir, 2012) (Fig. 1).

Turkey is favored by a large number of thermal springs known since classical and even prehistoric times. Most important geothermal exploration studies in Turkey began in 1962 by the General Directorate of Mineral Research and Exploration (MTA). There are a total of about 1,500 thermal and mineral water spring groups sped all over the country (Simsek et al., 2002; MTA, 1980; Simsek, 2009). The highest $\left(295^{\circ} \mathrm{C}\right)$ bottom hole temperatures have been measured in central Turkey. In Turkey, geothermal energy is also used in various applications such as power generation, greenhouse, district heating, industrial processes, and balneology. The installed capacity is $3322 \mathrm{MWt}$ for direct use (heating) and 1053 MWe for power generation (Akkuş, 2017). The application of geothermal energy for power generation has increased exponential in Turkey (Fig. 2).

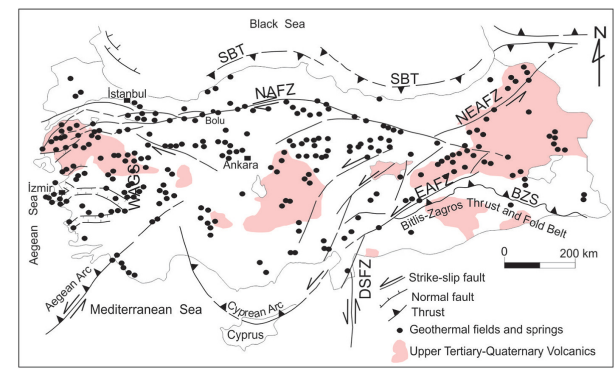

Figure 1. Simplified tectonic map of Turkey showing major neotectonic structures, volcanic province and geothermal spring area in Turkey (from Şimşek et al., 2002; Yiğitbaş et al., 2004).

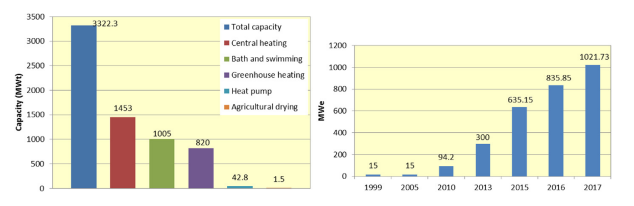

Figure 2. Application of geothermal system in Turkey a) direct use and b) power generation.

\section{ARSENIC IN GEOTHERMAL FLUID}

Based on the tectonic characteristics and the geological structure, many parts of Turkey are likely to have arsenic containing geological formations. Particularly, high arsenic levels have been naturally detected in along the fault system where volcanic, metamorphic and sedimentary formations out croup. The especially 

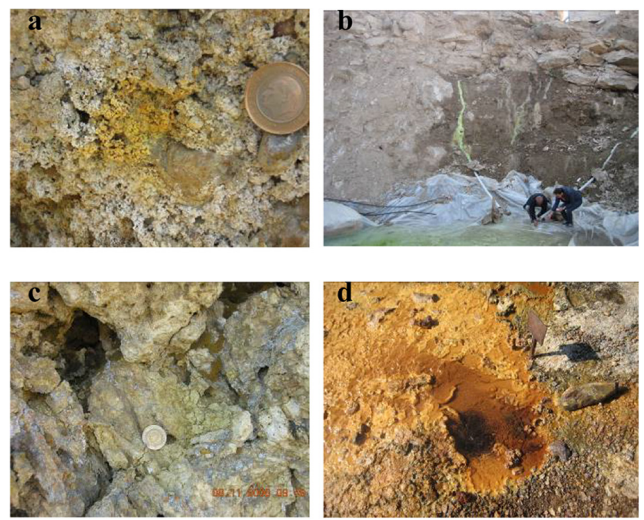

Figure 3. Alteration zone which is including arsenic (a: Lif (Siirt), b: Alaşehir (Manisa), c: Varto (Muş) and d: Tuzla (Çanakkale)).

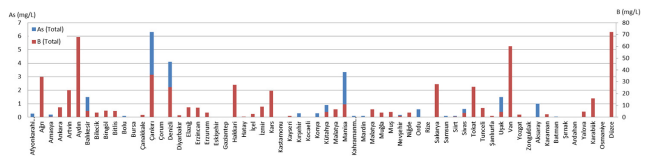

Figure 4. Concentration of arsenic in some geothermal field in Turkey (Some data taken from MTA, 2005).

volcanic activity led to the delineation of wide-ranging areas of alteration within mineral assemblages, from advanced argillic type to silica type to prophylitic type at deep levels (Fig. 3). The advanced argillic alteration zones are typified by enrichment of sulfur in volcanic rocks that have been dominant in the geological formation of Turkey is the primary mechanism for the presence of numerous trace elements in earth's crust, including but not limited to arsenic (Baba \& Gunduz, 2010; Baba \& Sözbilir, 2012). The concentration of arsenic in geothermal fluid changes in each field because of geological properties. The concentration of arsenic is range from 10 to $6936 \mathrm{mg} \mathrm{L}^{-1}$. The highest As concentration was found in the Hamambogazi (Uşak) geothermal spring with values of $6936 \mathrm{mg}$ $\mathrm{L}^{-1}$. The concentration of arsenic in some geothermal field is given in Figure 4. Except for arsenic, boron values also are quite in the geothermal system of Turkey. The concentration of boron reaches about $70 \mathrm{mg} \mathrm{L}^{-1}$ in some geothermal field such as Aydın, Manisa and Düzce Region. Boron concentration is related to volcanic and sedimentary rocks, but may also be controlled by degassing of magma intrusive (Baba \& Armmansson, 2006).

Figure 5 illustrates dominant hydrochemical features of geothermal fluid in Turkey. Each geothermal fluid has different compositions generally most of geothermal fluids which have a deep circulation are of $\mathrm{Na}-\mathrm{HCO}_{3}^{-}$type, whereas shallow fluids are mostly of the $\mathrm{Ca}-\mathrm{HCO}_{3}^{-}$type. Along the coastal region such as western Turkey, hot spring exhibited a Na-Cl type with high concentrations of $\mathrm{Na}^{+}$and $\mathrm{Cl}^{-}$.
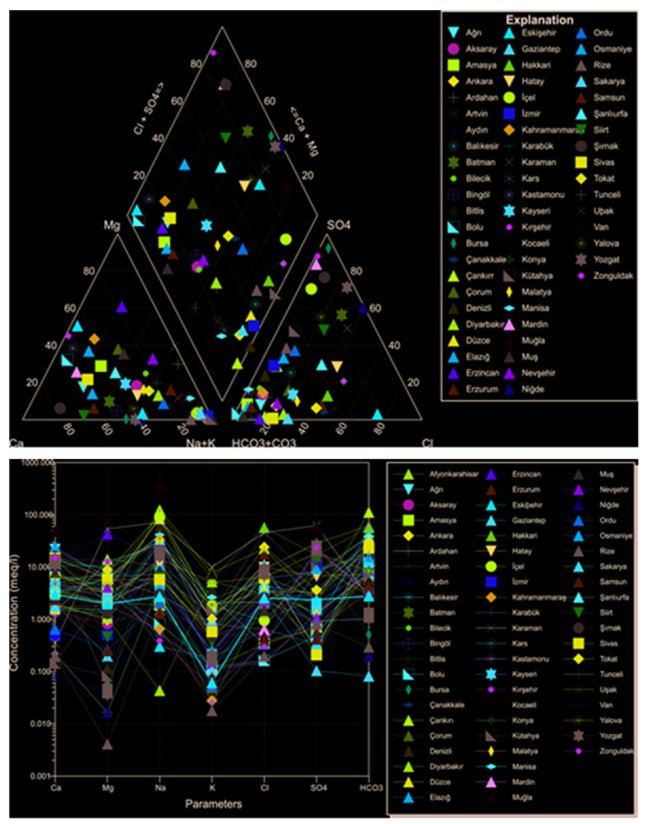

Figure 5. Chemical properties of geothermal fluid in Turkey a) Piper diagram and b) Schoeller diagram.

\section{CONCLUSIONS}

The study shows that geothermal fluid has a different water types in the different region and some geothermal fields have high concentrations of arsenic. Re-injection is one of the important processes to minimize environmental problem and sustainability of the system. It was observed that the deterioration of local shallow groundwater resources through arsenic contamination was due to the mixing of geothermal fluid or utilization of geothermal resources for energy regeneration. Therefore, proper management and control strategy must be adopted in order to ensure environmental safety to freshwater resources which is currently under threat from geothermal (Bundschuh et al., 2013).

\section{REFERENCES}

Akkuş, İ. 2017. Importance of geothermal energy in Turkey. TMMOB, JMO, Mavi. Gezegen. 23: 25-39.

Baba, A. \& Ármannsson, H. 2006. Environmental impact of the utilization of a geothermal area in Turkey. Energ. Source 1(3): 267-278.

Baba, A. \& Gunduz, O. 2010. Effect of alteration zones on water quality: a case study from biga peninsula, turkey. Arch. Environ. Con. Tox. 58(3): 499-513.

Baba, A. \& Sözbilir, H. 2012. Source of arsenic based on geological and hydrogeochemical properties of geothermal systems in Western Turkey. Chem. Geol. 334: 364-377.

Bozkurt, E. 2001. Neotectonics of Turkey - a synthesis. Geodin. Acta 14(1-3): 3-30. 
Bundschuh, J., Maity J. P., Nath B., Baba A., Gunduz O., Kulp T.R., Jean J.S., Kar S., Tseng Y., Bhattacharya P. \& Chen C.Y. 2013. Naturally occurring arsenic in terrestrial geothermal systems of western Anatolia, Turkey: potential role in contamination of freshwater resources. J. Hazard. Mater. 262: 951-959.

Mineral Research and Exploration (MTA). 1980. Hot and Mineral Water Inventory. General Directorate of Mineral Research and Exploration (MTA), MTA Rap., Ankara.

Mineral Research and Exploration (MTA). 2005. Geothermal Resources in Turkey. General Directorate of Mineral Research and Exploration (MTA), MTA Rap.21, Ankara.

Mutlu, H. \& Güleç, N. 1998. Geochemical characteristics of thermal waters from Anatolia (Turkey). J. Volcanol. Geoth. Res. 85: 495-515.
Simsek, S, Yildirim, N., Simsek, Z.N. \& Karakus, H. 2002. Changes in geothermal resources at earthquake regions and their importance. Proceedings of Middle Anatolian Geothermal Energy and Environmental Symposium, pp. $1-13$.

Simsek, S. 2009. Geothermal energy development possibilities in Turkey. NUMOW Conference on 'Geothermal Energy in Turkey', Potsdam-Germany, 1 October, 1-6.

Yigitbas, E., Elmas, A., Sefunc, A. \& Ozer, N. 2004. Major neotectonic features of eastern Marmara region, Turkey: development of the Adapazari-Karasu corridor and its tectonic significance. Geol. J. 39(2): 179-198. 


\title{
Exploring arsenic and other geogenic groundwater contaminants in the vast and scarcely studied Amazon Basin
}

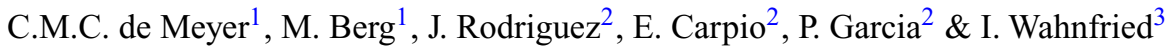 \\ ${ }^{1}$ Eawag, Swiss Federal Institute of Aquatic Science and Technology, Dübendorf, Switzerland \\ ${ }^{2}$ UNI, Universidad Nacional de Ingeniería, Lima, Peru \\ ${ }^{3}$ UFAM, Universidade Federal do Amazonas, Manaus, Brazil
}

\begin{abstract}
We conducted groundwater surveys in the Amazon Basin to determine the occurrence and distribution of arsenic and other contaminants. Initial results indicate that in groundwater resources in the recent floodplains of the Amazon River and of other white-water rivers, arsenic concentrations are often above the WHO-guideline value of $10 \mu \mathrm{g} \mathrm{L}^{-1}$ for drinking water. We compared the chemical analyses with geospatial data to identify vulnerable areas in the whole region. Understanding the regional geochemical mechanism(s) triggering the enrichment of arsenic in groundwater is important to raise awareness and implement mitigation where needed.
\end{abstract}

\section{INTRODUCTION}

To date, the groundwater quality in the Amazon region is very poorly known. This is of particular concern because people in both rural and urban areas rely on groundwater as their source of drinking water.

The Amazon Basin covers a vast region with heterogeneous geological and geographical features. In the floodplains of the Amazon river, and some of its main tributaries, high loads of Andean sediments get buried together with fresh organic matter. In those areas, reducing conditions in the subsurface are to be expected. The question remains if, where, and to what extend this may lead to reductive dissolution of arsenic and other redox sensitive elements in groundwater in concentrations harmful for human health. We seek answers to these questions by combining local scale groundwater surveys in selected areas of the Amazon Basin, with predictions on a regional scale using geospatial data.

\section{METHODS}

We sampled groundwater from domestic and community wells in the Peruvian Amazon (see Fig. 1). We chose the locations to be able to study groundwater from various depositional environments. In addition to

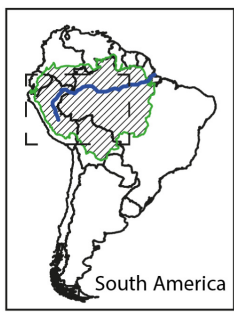

DV Amazon watershed

$\sim$ Amazon river

0 - 200 m.a.s.l.

200 - 7000 m.a.s.l.
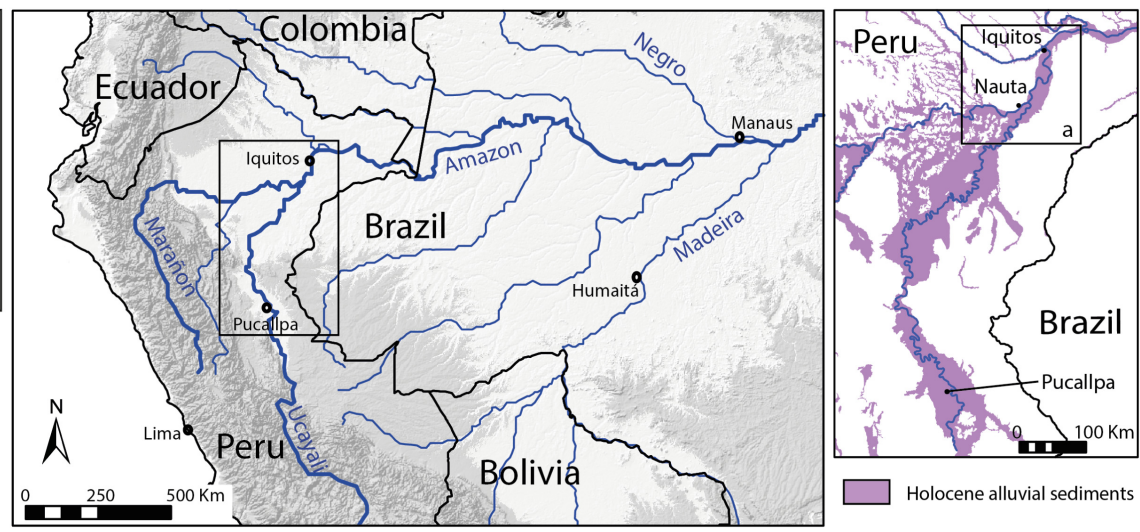

Figure 1. Location of the studied areas in the Western Amazon in Peru. Reducing subsurface conditions, and hence arsenic contaminated groundwater, is expected in the Holocene alluvial deposits along the Amazon River and some of its' main tributaries. Adapted from de Meyer et al. (2017). 
arsenic we analyzed some 50 groundwater parameters including major and minor elements.

We linked the groundwater data to environmental factors such as geology, topography, river geomorphology and soil, with the aim to develop a predictive map on the distribution of arsenic contamination on the sub-continental scale (Bretzler et al., 2017, RodriguezLado et al., 2013).

\section{RESULTS AND DISCUSSION}

\subsection{Groundwater survey}

Groundwater arsenic concentrations exceeded the WHO-limit of $10 \mu \mathrm{g} \mathrm{L}^{-1}$ (WHO, 2011) in a considerable amount of wells. Maximum values up to $700 \mu \mathrm{g} \mathrm{L}^{-1}$ were determined. High As-groundwater is of the $\mathrm{Ca}-\mathrm{Mg}-\mathrm{HCO}_{3}$ type, has a negative redox potential, slightly acidic $\mathrm{pH}$ and elevated concentrations of $\mathrm{Fe}, \mathrm{Mn}$, dissolved organic carbon, phosphate and ammonium (de Meyer et al., 2017). Based on these hydrochemical characteristics we concluded that arsenic is likely released by reductive dissolution of Fe-(hydr)oxides.

\subsection{Distribution of arsenic geogenic contamination}

de Meyer et al. (2017) observed that the distribution of arsenic in groundwater is linked to the depositional environment of the aquifer sediments. The contaminated wells tap groundwater from young alluvial deposits along the Amazon river and its main tributaries, as illustrated in Figure 2. These so-called white water rivers originate in the Andes and carry a high

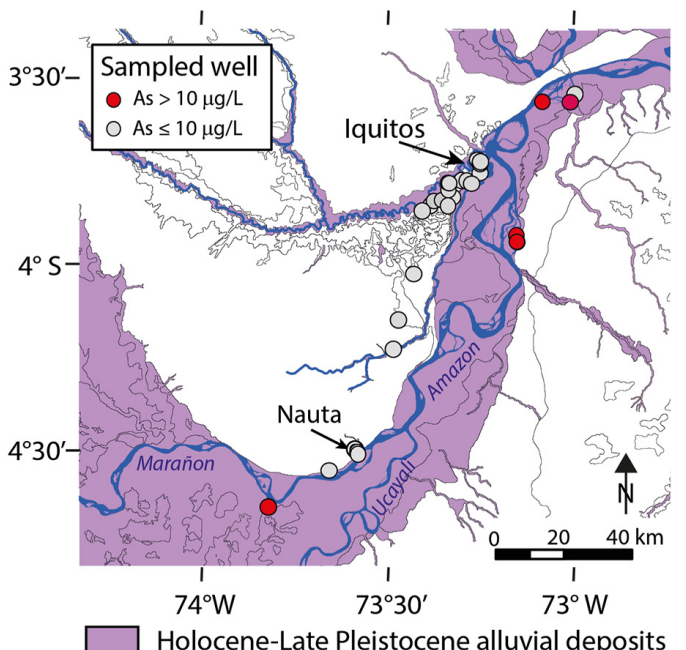

Figure 2. Indication of arsenic contaminated and non-contaminated wells around the city of Iquitos, in the Peruvian Western Amazon. Note that the wells where arsenic contamination was found are located in the floodplain of the Amazon river, i.e. on the recent alluvial deposits. (After de Meyer et al., 2017). sediment load. We used these observations to delineate the areas at risk of arsenic contaminated groundwater.

The effectiveness of the use of a small number of geological and hydrogeochemical parameters as spatial proxies to predict the regional distribution of high and low risk to arsenic concentrations has been demonstrated for As-affected basins in e.g. South-East Asia (Winkel et al., 2008). The Amazon Basin has hydrological and climatic conditions similar to Southeast Asia. We therefore tested the relevance of the parameters used in the model of Winkel et al. (2008), and explored the significance of other parameters, to provide a risk map for the Amazon region.

\section{CONCLUSION}

Our study provides first insights on the presence and distribution of arsenic in groundwater resources of the Amazon Basin. The high concentrations of arsenic encountered in groundwater along the populated floodplains of the Amazon river require urgent investigation on possible health effects.

\section{ACKNOWLEDGEMENTS}

The authors would like to thank Caroline Stengel, Thomas Rüttimann, Numa Pfenninger and the AuA laboratory at Eawag for chemical analysis of the samples. We are grateful to the well owners for access to their wells, and permission for sampling. The ETRASteam of PAHO in Lima and the DIRESA of Peru are sincerely thanked for their logistic support.

\section{REFERENCES}

Bretzler, A., Berg, M., Winkel, L., Amini, M., RodriguezLado, L., Sovann, C., Polya, D.A. \& Johnson, A. 2017. Geostatistical modelling of arsenic hazard in groundwater. In "Best Practice Guide on the Control of Arsenic in Drinking Water", Eds. Bhattacharya P., Polya D.A., Jovanovic D. IWA Publishing, London, UK. 153-160.

de Meyer, C.M.C., Rodríguez, J.M., Carpio, E.A., García, P.A., Stengel, C. \& Berg, M. 2017. Arsenic, manganese and aluminum contamination in groundwater resources of Western Amazonia (Peru). Sci. Total Environ. 607-608: 1437-1450.

Rodriguez-Lado, L., Sun, G., Berg, M., Zhang, Q., Xue, H., Zheng, Q. \& Johnson, C.A. 2013. Groundwater arsenic contamination throughout China. Science 341: 866-868.

WHO. 2011. Guidelines for Drinking-Water Quality. 4th ed. (Geneva).

Winkel, L., Berg, M., Amini, M., Hug, S.J. \& Johnson, A.C. 2008. Predicting groundwater arsenic contamination in Southeast Asia from surface parameters. Nat. Geosci. 1: 536-542. 


\title{
Arsenic volume estimates in Holocene clay plug sediments in Bihar, India
}

\author{
S. Kumar, M.E. Donselaar \& F. Burgers \\ Department of Applied Geoscience and Engineering, Delft University of Technology, Delft, The Netherlands
}

\begin{abstract}
Shallow aquifers in the densely-populated areas of the Indo-Gangetic plain are severely polluted with arsenic (As). The occurrence of As and its spatial concentration variability are conditioned by the geomorphological setting of the Holocene floodplain, with the highest concentrations in elevated point-bar surrounded by clay-filled oxbow lakes (clay plugs). The work hypothesis is that the As is locally derived from the clay plugs. In this study, the potential As volume in the clay plugs is calculated, and the migration process of arsenic from clay plug to adjacent point bar is studied. Satellite data in combination with a side-scan sonar survey in present-day oxbow lakes, and As concentrations in sediment from a well were used to calculate the sediment volume of the clay plug, the potential volume of As, and the contact area between the clay plug and adjacent point bar, and to estimate the initial diffusion flux of dissolved As from clay plug to the adjacent point bar.
\end{abstract}

\section{INTRODUCTION}

Elevated sandy point bars surrounded by clay-filled oxbow lakes (clay plugs) in Bhojpur and Buxar districts of Bihar (Fig. 1) are hotspots for arsenic (As). Arsenic concentrations in groundwater of the point bars are characterized by a large spatial variation over short distances. Donselaar et al. (2016) proposed a generic model in which As is sourced from the clay plugs surrounding the point bars, and subsequently migrates to the groundwater in the permeable point bar sand. The present paper aims to provide insight in the potential As volume in clay plugs of the Holocene Ganges River floodplain, and to present ideas on the migration processes of As from clay plug to adjacent point bar.

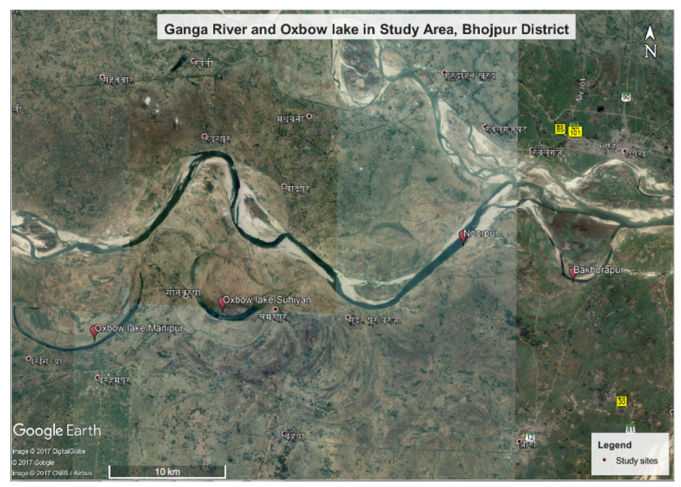

Figure 1. Ganges River and oxbow lakes in the study area.

\section{METHODS}

Clay plug surface areas were mapped with sentinel satellite data and Google Earth-Pro imagery. Clay plug volumes and contact areas between the clay plug and adjacent point bar were calculated in Matlab by combining the surface areas with bathymetric profiles derived from a side-scan sonar survey in recent oxbow lakes along the Ganges River, Bhojpur District in Bihar (Fig. 2). Arsenic concentrations in sediments from a borehole study in Holocene clay plugs in the Haringhata district (West Bengal, India) of Ghosh et al. (2015) were used to calculate As volumes contained in the clay plug deposits.

\section{RESULTS AND DISCUSSION}

\subsection{Calculation of potential arsenic volumes}

Surface areas of the selected clay plugs ranged from $10^{6}$ to $10^{7} \mathrm{~m}^{2}$. Maximum depth of the oxbow lakes

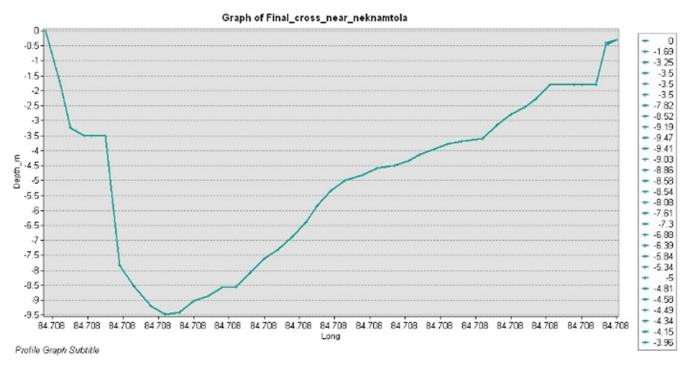

Figure 2. Sonar bathymetric profile of an oxbow lake along the Ganges River in the study area. 
in the bathymetric study was $9.47 \mathrm{~m}$. Arsenic content in cores from wells averaged $17.7 \mathrm{mg} \mathrm{kg}^{-1}$ sediment (Ghosh et al., 2015). The calculated sediment volume of clay plugs ranges from $10^{6}$ to $10^{8} \mathrm{~m}^{3}$. The resultant As volume contained in the clay plug sediment ranges from $10^{5}$ to $10^{6} \mathrm{~kg}$. The contact area between the clay plug and the adjacent point bar was in the order of $10^{6}$ to $10^{7} \mathrm{~m}^{2}$.

\subsection{Estimation of diffusion fluxes}

There are no known driving forces in the point bar for the release of As from its solid state and the concentration of soluble As in the pore fluid of the point bar sands is negligible. The discharge depends linearly on the hydraulic conductivity, this soil property is of large influence over time. The discharge also depends on the present As volume. Over time the volume will decrease and thus the discharge will decrease. The discharge decrease is exponentially over time. Equation (1) describes Fick's first law of diffusion process with two assumptions, firstly that the system must be in steady state, and secondly that the medium must be homogeneous.

$\mathrm{J}=-\mathrm{D} \nabla \mathrm{C}$

$\mathrm{D}$ is the diffusion coefficient, a material specific property, and $\mathrm{C}$ is the concentration. With some modifications Fick's first law for transport through a membrane is given by equation (2)

$\mathrm{J}=\mathrm{K} \nabla \mathrm{C}$

Where $\mathrm{J}$ is diffusion flux $\left[\mathrm{mol} \mathrm{m}^{-2} \mathrm{~s}^{-1}\right], \mathrm{K}$ the hydraulic conductivity of the medium $\left[\mathrm{m} \mathrm{s}^{-1}\right]$ and $\Delta \mathrm{C}$ the difference in concentration $\left[\mathrm{mol} \mathrm{m}^{-3}\right]$. The hydraulic conductivity value, which is crucial to the modified version of Fick's first law, was considered to be within the following range: a minimal value of $10^{-8} \mathrm{~m} \mathrm{~s}^{-1}$ and a maximal value of $10^{-7} \mathrm{~m} \mathrm{~s}^{-1}$ (Bear, 1972). Initial diffusion flux was calculated based on Fick's First Law, and ranged between $10^{1}$ to $10^{2} \mathrm{~g} \mathrm{~m}^{-2} \mathrm{y}^{-1}$.

\subsection{Discussion}

The presence of high TOC concentrations and lack of water circulation in the deeper part of the oxbow lake (hypolimnion) contributes to the development of anoxic conditions that favor the desorption of As from FeOOH (e.g. McArthur et al., 2004). Ghosh et al. (2015) reported TOC concentrations of $0.7 \%$ in clay plug deposits at shallow depths (6-12 $\mathrm{m})$ in a meandering river geomorphology in Haringhata (Nadia district, West Bengal, India). Advection and diffusion are two processes of As movement from clay plug to point bar. In case of gravitational, compaction-driven expulsion of pore fluid movement, advection occurs while the difference in concentration creating gradient favors diffusion. The hydraulic conductivity is linearly related to the diffusion flux.

\section{CONCLUSIONS}

Sediment volume of clay plugs in the floodplain along the present-day Ganges River, as calculated from remote sensing data, range from $10^{6}$ to $10^{8} \mathrm{~m}^{3}$. Arsenic concentrations from borehole data in Holocene clay plugs in West Bengal allowed for the estimate of As volume in each of the studied clay plugs. The As content ranges from $10^{5}$ to $10^{6} \mathrm{~kg}$ per clay plug. Based on Fick's First Law the initial diffusion flux was calculated and ranges from 10 to $10^{2} \mathrm{~g} \mathrm{~m}^{-2} \mathrm{yr}^{-1}$. The results of this study are crucial for the dynamic flow modelling of As-contaminated aquifers in the affected areas, and helps to develop guidelines for the location of safe, As-free groundwater extraction.

\section{ACKNOWLEDGEMENTS}

Financial support for this study from the NWOWOTRO research program "Urbanising Deltas of the World" (UDW) is gratefully acknowledged.

\section{REFERENCES}

Bear, J. 1972. Dynamics of fluids in porous media. Elsevier, New York, USA.

Donselaar, M.E., Bhatt, A.G. \& Ghosh, A.K. 2016. On the relation between fluvio-deltaic flood basin geomorphology and the wide-spread occurrence of arsenic pollution in shallow aquifers. Sci. Total Environ. 574: 901-913.

Ghosh, D., Routh, J., Dario, M. \& Bhadury, P. 2015. Elemental and biomarker characteristics in a Pleistocene aquifer vulnerable to arsenic contamination in the Bengal Delta Plain, India. Appl. Geochem. 61: 87-98.

McArthur, J.M., Banerjee, D.M., Hudson-Edwards, K.A., Mishra, R., Purohit, R., Ravenscroft, P., Cronin, A., Howarth, R.J., Chatterjee, A., Talukder, T., Lowry, D., Houghton, S. \& Chadha, D.K. 2004. Natural organic matter in sedimentary basins and its relation to arsenic in anoxic groundwater: the example of West Bengal and its worldwide implications. Appl. Geochem. 19: 1255-1293. 


\title{
Steady-state groundwater arsenic concentrations in reducing aquifers
}

\author{
B.C. Bostick ${ }^{1}$, A.A. Nghiem ${ }^{1}$, A. van Geen ${ }^{1}$, J. Sun ${ }^{2}$, B.J. Mailloux ${ }^{3}$, P.H. Viet ${ }^{4}$ \& P.T.K. Trang ${ }^{4}$ \\ ${ }^{1}$ Barnard College and Lamont-Doherty Earth Observatory, Columbia University, New York, USA \\ ${ }^{2}$ University of Western Australia \& CSIRO Land and Water, Perth, WA, Australia \\ ${ }^{3}$ Department of Environmental Sciences, Barnard College, New York, NY, USA \\ ${ }^{4}$ CETASD, Vietnam National University, Hanoi, Vietnam
}

\begin{abstract}
Arsenic is a common soil and groundwater contaminant in much of the world. Groundwater arsenic is commonly derived from the reductive dissolution of arsenic-bearing iron oxides. Despite considerable efforts, it is still difficult to predict the aqueous concentration of arsenic in the transitional redox environments where arsenic release occurs, or in the reduced sediments through which it is transported. Equilibrium-based partitioning models often no more accurate that simple adsorption isotherms or partition coefficients in these environments. Here, we develop and evaluate a novel kinetics-based approach that incorporates knowledge of the solid-phase, to predict arsenic concentrations. This model defines the steady-state aqueous concentration of arsenic as a function of iron oxide dissolution rate and readsorption of arsenite and arsenate. This model uses measured iron and arsenic redox status to successfully describe As concentrations in redox profiles in heterogeneous Bangladeshi and Vietnamese aquifers. These data imply that the speciation of arsenic, which affects readsorption rates, are the dominant variable controlling As retention, and that iron mineralogy plays an indirect role by affecting the rate of biological reduction.
\end{abstract}

\section{INTRODUCTION}

Groundwater arsenic (As) contamination is a global public health problem and also a concern at hundreds of U.S. Superfund sites. A considerable body of research has established that arsenic enters groundwater most commonly through the biological reduction of As-bearing iron oxides. Despite this realization, we are still not able to adequately predict arsenic concentrations at specific sites, or determine how they may be affected as the system evolves. Most predictions are based equilibrium retention by the sediments and predict changes in As concentrations resulting in a change in sediment mineralogy and/or redox status and the change in the quantity of substrate and/or As in the solid-phase. These approaches are broadly consistent with regional trends in that older sediments tend to be oxidized and contain less As due to flushing, but they break down at smaller scales. In this research, we propose that kinetics is the dominant factor that affects As partitioning, and develop a quantitative model to test this hypothesis that is capable of describing As concentrations at specific depths within several depth profiles of dissolved arsenic levels in Vietnam.

\subsection{Modelling}

This simple model is based on the hypothesis that dissolved As is a chemical intermediate between the reductive dissolution that puts it into solution, and adsorption or precipitation processes that remove it from solutions. It assumes that the dissolved As concentrations are at steady-state because retention processes are sufficient that most of the As remains in the solid phase. This model assumes As only resides on $\mathrm{Fe}(\mathrm{III})$ minerals, and that the reduction of those minerals releases them proportionally to concentration. The rate of Fe reduction in the sediments can vary due to many factors but under in situ conditions varies strongly with mineralogy (Postma et al., 2010). The rate of readsorption of arsenic depend on the availability (concentration) of iron oxide substrates, and the concentration and oxidation state of As. Arsenate and arsenite are considered independently - the rate of their release is determined by their abundance in the solid-phase. Because adsorption rates for $\mathrm{As}(\mathrm{V})$ on $\mathrm{Fe}(\mathrm{III})$ oxides are considerably more rapid than As(III) (Kanel et al., 2006), As oxidation state plays a significant, albeit indirect role in regulating As levels.

\subsection{Fe and As speciation}

This model requires knowledge about the solidphase speciation of both $\mathrm{Fe}$ and As. The concentration of solid-phase $\mathrm{Fe}(\mathrm{II})$ and $\mathrm{Fe}(\mathrm{III})$ oxides is determined using synchrotron-based X-ray absorption spectroscopy (XAS) using established techniques ${ }^{5}$. We convert the fractional speciation determined by XAS to solid phase concentrations of $\mathrm{Fe}$ (III) and As(III) 
or $\mathrm{As}(\mathrm{V})$ using X-ray fluorescence (XRF) data collected using a hand-held XRF. We have determined As and Fe speciation every $2 \mathrm{~m}$ for several sites where groundwater concentrations also vary with depth. This fine-scale sampling allows us to explain sharp gradients in groundwater arsenic that occur with depth, and to determine the relative roles of $\mathrm{Fe}(\mathrm{III})$ and $\mathrm{As}(\mathrm{V})$ reduction on regulating As levels.

\section{RESULTS AND DISCUSSION}

This research is unique in that it allowed us study the redox state in layered aquifers where both redox state and As concentrations varied considerably with depth, and where there were coupled changes in dissolved As levels. In most environments, $\mathrm{As}(\mathrm{V})$ and $\mathrm{Fe}(\mathrm{III})$ concentrations are high in the surface, and conditions become more reducing with depth. At most of our, $\mathrm{Fe}$ (III) concentrations decreased gradually with depth, while As reduction was a sharper transition that occurred below the zone where $\mathrm{Fe}(\mathrm{III})$ reduction became apparent. Dissolved As concentrations generally were low at the surface where systems were more oxidized, and there was a sharp gradient between low and high dissolved As concentrations. In more complex layered aquifers systems containing oxidized Pleistocene sediments and reduced Pleistocene sediments, the model was also effective in that dissolved As concentrations oscillated with sediment properties.

The model was able to accurately predict dissolved As levels within a factor of 2 at all depths using measured Fe(III) oxide, As(III) and As(V) solid-phase concentrations, and without any information about groundwater composition. Dissolved As levels mirrored As speciation. Based on these data, we were able to model dissolved As concentrations over a wide

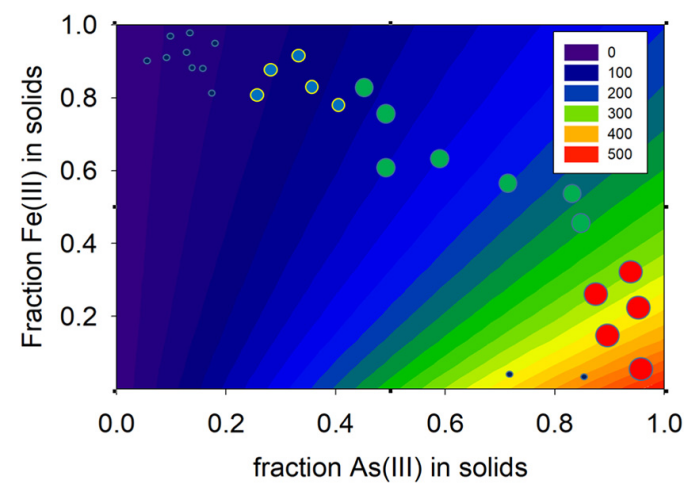

Figure 1. Modeled contour plot of dissolved As concentrations (legend shows color scale) as a function of solid-phase $\mathrm{Fe}$ and As oxidation state, with selected data plotted on the figure with symbols sizes and colors proportional to concentration. range of As and $\mathrm{Fe}$ oxidation states given a small number of assumptions about the concentration of $\mathrm{Fe}$ and As in the sediments, and the reactivity of the Fe(III) oxides in the system (Fig. 1). Most As concentrations from sediment profiles was effectively described, with the possible exception of some highly reduced sediments.

\section{CONCLUSIONS}

The model successfully predicts dissolved As concentrations without refinement of kinetic parameters. This adherence suggests that the assumption that dissolved As can be thought of effectively as a reactive intermediate in the environment.

There are several important applications of this model. First, As concentrations appear to vary with depth because of differences in the rates of retention of $\mathrm{As}(\mathrm{III})$ and $\mathrm{As}(\mathrm{V})$ rather than differences in their equilibrium adsorption isotherms on aquifer sands. Second, because redox gradients of Fe and As vary from each other spatially, it allows us to identify the relative roles of As and $\mathrm{Fe}$ reduction on generating high-As groundwater. Fe gradients are more gradual, and even in most reduced sediments, a considerable fraction of Fe(III) phases remain. Dissolved As concentrations will be highest when reduction rates are fastest, meaning that As concentrations will be elevated most in the presence of reactive Fe oxides such as ferrihydrite. Third, As oxidation state appears to play a much more important role in regulating As levels than does $\mathrm{Fe}$ speciation. This model does not consider the rates of As reduction, however, parallel recent research suggests that biologically mediated $\mathrm{As}(\mathrm{V})$ reduction is prevalent where As(III) is found. These results suggest that As levels will be highest where there is a combination of high levels of As(III) retained on reactive $\mathrm{Fe}(\mathrm{III})$ oxides, and that remediation efforts should concentrate on modulating the rates of retention to be effective.

\section{ACKNOWLEDGEMENTS}

U.S. National Institute of Environmental Health Sciences (grant ES010349 and ES009089) and U.S. National Science Foundation (grants 1521356 and 0911557).

\section{REFERENCES}

Kanel, S.R., Greneche, J.M. \& Choi, H. 2006. Arsenic(V) removal from groundwater using nano scale zero-valent iron as a colloidal reactive barrier material, Environ. Sci. Technol. 40: 2045-2050.

Postma, D., Jessen, S., Hue, N.T.M., Mai, T.D., Koch, C.B., Viet, P.H., Nhan P.Q. \& Larsena, F. 2010. Mobilization of arsenic and iron from red river floodplain sediments, vietnam. Geochim. Cosmochim. Acta 74: 3367-3381. 


\title{
Arsenic and polymetallic contaminants in groundwater of the arid regions of South Africa
}

\author{
T.A. Abiye \\ School of Geosciences, University of the Witwatersrand, Johannesburg, South Africa
}

\begin{abstract}
In South Africa, the majority of rural water supply comes from groundwater hosted within the weathered and fractured crystalline rocks. The main minerals that are responsible for arsenic release into groundwater in South Africa are arsenopyrite $(\mathrm{FeAsS})$, lollingite $\left(\mathrm{FeAs}_{2}\right)$ and scorodite $\left(\mathrm{FeAsO}_{4} \cdot 2 \mathrm{H}_{2} \mathrm{O}\right)$, where scorodite is an alteration product of arsenopyrite due to prolonged water-rock interaction process. Owing to the release of arsenic from highly mineralized rocks, its concentration in the groundwater reaches up to $253 \mu \mathrm{g} \mathrm{L}^{-1}$ (south western part of the country), $6150 \mu \mathrm{g} \mathrm{L}^{-1}$ (west of Johannesburg), about $500 \mu \mathrm{g} \mathrm{L}^{-1}$ in the Karoo aquifers. Acid mine drainage is also found to be important source of arsenic and other toxic metals in the environment.
\end{abstract}

\section{INTRODUCTION}

In regions that are characterized by climatic aridity and minimal rainfall, groundwater from weathered and fractured crystalline rock aquifers is a primary source of water supply for various community activities. The development of groundwater resources from these aquifers has been regarded as a very important deriver for economic growth of the country owing to its availability at shallow depth $(\approx 40 \mathrm{~m})$ and scarcity of surface water sources often characterized by poor water quality due to arsenic (As) and polymetallic contaminants. In several parts of the world, especially in south-east Asia, high As concentration is prevalent in groundwater from the sedimentary aquifers with enriched organic matter (Ahmed et al., 2004; Bhattacharya et al., 2002a,b, 2004; Mukherjee et al., 2011; Nriagu et al., 2007) related to organic rich sediments. The geology of aquifers that host As in South Africa have undergone large-scale mineralization, where As occurs in sulphide ores such as auriferous, stanniferous and antimonial deposits (Hammerbeck, 1998) that is being released into groundwater through leaching process. Arsenic, $\mathrm{U}$ and Se are more mobile under a wider range of naturally occurring groundwater conditions; hence they pose a potentially more widespread problem than other trace constituents (Sami \& Druzynski, 2003). Extensive mineralization of rocks is also responsible for the release of toxic metals into the groundwater.

\section{MATERIALS AND METHODS}

Extensive literature assessment was conducted in order to gather relevant information on the arsenic and toxic metal concentration in the groundwater system of South Africa. In order to get a first-hand information, twenty groundwater samples from granitic aquifers were collected and analyzed for 24 metals, including arsenic. The water samples were diluted in $50 \mathrm{~mL}$ polypropylene volumetric flasks with ultra-pure water and acidified with $2 \% \mathrm{HNO}_{3}$ and analyzed by IC-PMS.

\section{RESULTS AND DISCUSSION}

The geology of the main aquifers in South Africa is represented by weathered and fractured basement rocks, Bushveld igneous complex (basic and felsic intrusive rocks), dykes (pegmatite, syenite and dolerite), the Witwatersrand and Transvaal Supergroup meta-sedimentary rocks (quartzite, sandstone, shale, dolomite), the Karoo and Kalahari sedimentary rocks, meta-volcanic rocks (basalts, andesites and rhyolites) and unconsolidated costal sediments. The main minerals that are responsible for arsenic release into groundwater in South Africa are dominated by arsenopyrite (FeAsS) that has a widespread occurrence in the country, lollingite $\left(\mathrm{FeAs}_{2}\right)$ and scorodite $\left(\mathrm{FeAsO}_{4} \cdot 2 \mathrm{H}_{2} \mathrm{O}\right)$. Scordite is a main mineral phase in the withering zone. Arsenopyrite and other sulphide minerals are known to be susceptible to oxidation in near surface environments (Herath et al., 2016), where most boreholes tap water for community supply.

Owing to the release of arsenic from highly mineralized rocks into groundwater, its concentration in the groundwater reaches up to $253 \mu \mathrm{g} \mathrm{L}^{-1}$ (south western part of the country), $7000 \mu \mathrm{g} \mathrm{L}^{-1}$, west of Johannesburg (Sami \& Druzynski, 2003), about $550 \mu \mathrm{g} \mathrm{L}^{-1}$ in the Karoo aquifers, within the boreholes having variable depth. In general the arsenic content in the groundwater falls above the WHO drinking water limit $\left(10 \mu \mathrm{g} \mathrm{L}^{-1}\right)$. 
The abandoned gold tailings dams around the city of Johannesburg contain very high metal concentration that release metals into surface and ground water resources. For example, in the tailings dams the content of some metals such as $\mathrm{Cr}$ ranges from 170 to $310 \mathrm{mg} \mathrm{L}^{-1}, \mathrm{Co}=10-240 \mathrm{mg} \mathrm{L}^{-1}, \mathrm{Cu}=15-254 \mathrm{mg}$ $\mathrm{L}^{-1}$ and lead 6-34 $\mathrm{mg} \mathrm{L}^{-1}$. High uranium rich mine water with acidic $\mathrm{pH}$ decants continuously from abandoned mines into streams (Winde, 2006; Hobbs, 2011; Abiye, 2014; Abiye, et al., 2018). The high concentration of polymetallic contaminants in the groundwater was regulated by oxidation, leaching and precipitation processes besides water-rock interaction. The metal concentration in groundwater is in the order of $\mathrm{Fe}>\mathrm{Sr}>\mathrm{Zn}>\mathrm{B}>\mathrm{Mn}>\mathrm{Ni}>\mathrm{Ni}>\mathrm{Li}>\mathrm{Cr}>\mathrm{As}>\mathrm{U}$ that falls within the range of $14 \mu \mathrm{g} \mathrm{L}^{-1}$ for $\mathrm{U}$ and $3128 \mu \mathrm{g}$ $\mathrm{L}^{-1}$ for $\mathrm{Fe}$ in the Namaqualand groundwater (Abiye \& Leshomo, 2013). Fe is also the main component in the gold and coal mining regions as a result of acid mine drainage that reaches $890 \mathrm{mg} \mathrm{L}^{-1}$ (Abiye et al., 2011). In addition to the leaching of arsenic from sulphide minerals facilitated by oxidation process, oxidation of iron is also believed to contribute for the concentration of arsenic in the groundwater. The lack of aquifer flushing due to low groundwater recharge condition facilitates concentration of metals in the shallow aquifers besides severe evaporation process in the region. This zone is readily accessible by groundwater users for various economic activities.

\section{CONCLUSIONS AND RECOMMENDATIONS}

South Africa is endowed with a variety of economic minerals both metals and non-metals, which also host minerals responsible for arsenic and other toxic metals release into aquifers. Complex geochemical processes that involve oxidation and precipitation at acidic $\mathrm{pH}$ conditions are among few that mobilizes metals from host rocks into groundwater. It was also noted that acid mine drainage in the gold and coal mining areas is the primary media for arsenic and other toxic metal mobilization from sulphides and eventually contaminates water supply systems.

Due to the health related risk associated with arsenic, it is essential to take precautionary measure on boreholes with high content.

\section{ACKNOWLEDGMENT}

I would like to thank Prof. Prosun Bhattacharya for his encouragement that helped me to develop this abstract for As2018 conference.

\section{REFERENCES}

Abiye, T.A., Mengistu, H. \& Demlie, M.B. 2011. Groundwater resource in the crystalline rocks of the Johannesburg area, South Africa. J. Water Resour. Protection 3(4): 199-212.

Abiye, T.A. \& Leshomo J. 2013. Metal enrichment in the groundwater of the arid environment in South Africa. Environ. Earth Sci. 72: 4587-4598.

Abiye, T.A. 2014. Mine water footprint in the Johannesburg area: a review based on existing and measured data. South Afr. J. Geol. 117(1): 87-96.

Abiye, T.A, Mkansi, S., Masindi, K. \& Leshomo, J. 2018. Effectiveness of wetlands in retaining metals from mine water, South Africa. J. Water Environ. (in press).

Ahmed, K.M. Bhattacharya, P., Hasan, M.A., Akhter, S.H., Alam, S.M.M., Bhuyian, M.A.H., Imam, M.B., Khan, A.A. \& Sracek, O. 2004. Arsenic contamination in groundwater of alluvial aquifers in Bangladesh: An overview. Appl. Geochem. 19(2):181-200.

Bhattacharya, P., Frisbie, S.H., Smith, E., Naidu, R., Jacks, G. \& Sarkar, B. 2002a. Arsenic in the Environment: A Global Perspective. In: B.Sarkar (Ed.) Handbook of Heavy Metals in the Environment, Marcell Dekker Inc., New York, pp. 147-215.

Bhattacharya, P., Jacks, G., Ahmed, K.M., Khan, A.A. \& Routh, J. 2002b. Arsenic in groundwater of the Bengal Delta Plain aquifers in Bangladesh. Bull. Env. Contam. Toxicol. 69(4): 538-545.

Bhattacharya, P., Welch, A.H., Ahmed, K.M., Jacks, G. \& Naidu, R. 2004. Arsenic in groundwater of sedimentary aquifers. Appl. Geochem. 19(2):163-167.

Hammerbeck, E.C.I. 1998. Arsenic. In: The Mineral Resources of South Africa: Handbook, Council for Geoscience, 16, p. 40-45.

Herath, I., Bundschuh, J., Vithanage, M. \& Bhattacharya, P. 2016. Geochemical processes for mobilization of arsenic in groundwater. In: P. Bhattacharya, M. Vahter, J. Jarsjö, J. Kumpiene, A. Ahmad, C. Sparrenbom, G. Jacks, M.E. Donselaar, J. Bundschuh, \& R. Naidu (eds.) Arsenic Research and Global Sustainability As 2016". Interdisciplinary Book Series: "Arsenic in the Environment-Proceedings". Series Editors: J. Bundschuh \& P. Bhattacharya, CRC Press/Taylor and Francis (ISBN 978-1-138-02941-5), pp. 23-24.

Hobbs, P.J (Ed.) 2011. Situation assessment of the surface water and groundwater resource environments in the Cradle of Humankind World Heritage Site. Report prepared for the Management Authority. Department of Economic Development. Gauteng Province. South Africa. P424.

Mukherjee, A., Bhattacharya, P. \& Fryar, A. E. 2011. Arsenic and other toxic elements in surface and groundwater systems. Appl. Geochem. 26(4): 415-420.

Nriagu, J.O., Bhattacharya, P., Mukherjee, A.B., Bundschuh, J., Zevenhoven, R. \& Loeppert, R.H. 2007. Arsenic in soil and groundwater: an overview. In: Bhattacharya, P., Mukherjee, A.B., Bundschuh, J., Zevenhoven, R. \& Loeppert, R.H. (Eds.) Arsenic in Soil and Groundwater Environment: Biogeochemical Interactions, Health Effects and Remediation, Trace Metals and other Contaminants in the Environment, Volume 9, Elsevier B.V. Amsterdam, The Netherlands, pp. 3-60.

Sami, K. \& Druzynski, A.L. 2003. Predicted Spatial Distribution of Naturally Occurring Arsenic, Selenium and Uranium in Groundwater in South Africa-Reconnaissance Survey- WRC Report No. 1236/1/03.

Winde, F. 2006. Challenges for sustainable water use in dolomitic mining regions of South Africa- a case study of Uranium pollution: part 1 Sources and pathways. $J$. Phys. Geogr. 27 (4): 333-347. 


\title{
Effect of recharging water from Meghna River on the arsenic contaminated groundwater
}

\author{
H. Masuda ${ }^{1}$, N. Hirai ${ }^{1}$ \& A.H.M. Selim Reza ${ }^{2}$ \\ ${ }^{1}$ Department of Biology and Geosciences, Osaka City University, Sumiyoshi-ku, Osaka, Japan \\ ${ }^{2}$ Department of Geology and Mining, University of Rajshahi, Rajshahi, Bangladesh
}

\begin{abstract}
Groundwaters and aquifer sediments from Chundpur and its surroundings, along the downstream Meghna River at the meeting with Padma River, Bangladesh, were analyzed to document the mechanism of As contamination. The As was released in association with infiltration of surface water into the shallow groundwater aquifer without strong reduction. In situ chemical weathering and the following desorption at increasing $\mathrm{pH}$ would be the primary and secondary processes to release As into the groundwater of the studied area.
\end{abstract}

\section{INTRODUCTION}

Delta plain at the south of Bangladesh is one of the most arsenic (As) affected area of the world. In this area, microbial activity is presumed to cause reduction-dissolution of As from the aquifer sediments to groundwater. The reduction-dissolution occurs during the infiltration of surface water into the aquifer. In this study, the geochemistry of groundwaters and aquifer sediments was studied to reveal the role of recharging water from rivers, especially the main channel of Meghna.

\section{STUDY AREA AND METHODS}

\subsection{Study area and sample collection}

Study area is at the east side of meeting of Meghna (Brahmaputra) and Padma (Ganges) Rivers (Fig. 1). The area is in the modern delta plain. In this area, as similar to the surrounding areas in this delta plain, highly As contaminated groundwater appears in the wells.

Ninty-nine groundwater and five river water samples were collected from the five villages (Fig. 1) in March 2016. The waters were collected in plastic and glass bottles and acidified if it was needed for the analyses. Water temperature, electric conductivity, $\mathrm{pH}$, ORP and DO were measured in situ. Aquifer sediments were cored from two sites down to $35 \mathrm{~m}$ depths using a split barrel sampler in May 2015.

\subsection{Laboratory analyses}

Major and minor element chemistry of water samples were analyzed in the laboratory. The anions were analyzed by ion-chromatography, and major cations and minor elements including As were analyzed by ICP-MS.

Total As and major element chemistry of whole sediment samples were analyzed by ICP-MS after alkali-fusion and X-ray fluorescence photometry respectively. Arsenic and the related elements of the sediments were also analyzed by differentially chemical extraction according to BCR method slightly modified to estimate the phases of mobile As (Rauret et al., 1999).

\section{RESULTS AND DISCUSSION}

\subsection{Water chemistry}

Major element chemistry was abundantly $\mathrm{Ca}-\mathrm{HCO}_{3}$ type in the three villages close to the Meghna River (MAT, CHU and FAR) and $\mathrm{Na}-\mathrm{HCO}_{3}$ type in the two inland villages (SHA and HAJ). In the all villages, groundwaters were occasionally affected by $\mathrm{Na}-\mathrm{Cl}$ type water, presumably originated from the household waster waters.

Arsenic concentration is generally high in the groundwaters $<70 \mathrm{~m}$ depths; the maximum concentration was $0.74 \mathrm{mg} \mathrm{L}^{-1}$. The groundwaters $>100 \mathrm{~m}$ depths were almost free from As. Riverwaters contained As $<5 \mu \mathrm{g} \mathrm{L}^{-1}$. Level of As is high in the HAJ, $\mathrm{CHU}$ and FAR villages, of which average As concentration of groundwaters from $<70 \mathrm{~m}$ depths wells were $0.44 \mathrm{mg} \mathrm{L}^{-1}$, indicating no relation of As level to the distance from the river. ORPs were the high of the groundwaters from FAR and HAJ compared with those of the other three villages, and the ranges of ORP did not directly related to the As concentration (Fig. 2). Especially, the groundwaters from HAJ gave wide variation of the ORP $(-20 \sim-155 \mathrm{mV})$ and high range of As $\left(0.24 \sim 0.63 \mathrm{mg} \mathrm{L}^{-1}\right.$ except one; $-90 \mathrm{mV}$ 


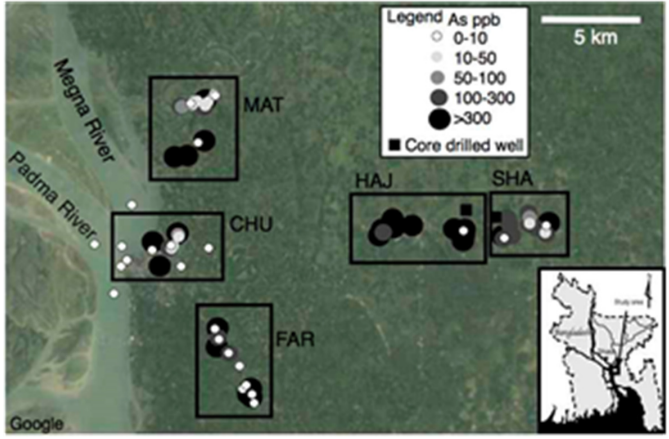

Figure 1. Study area and As concentration of groundwaters of Chandpur and its surroundings.

and $\left.0.006 \mathrm{mg} \mathrm{L}^{-1} \mathrm{As}\right)$. The groundwater giving the high ORP $(-20 \mathrm{mV})$ had $0.63 \mathrm{mg} \mathrm{L}^{-1}$ As. Iron concentration increased with decreasing ORP (not shown). Thus, in the studied area, reduction-dissolution of Fe-phases does not simply work to increase the As concentrations.

Major ion compositions of the groundwaters containing high As were mostly of $\mathrm{Ca}-\mathrm{HCO}_{3}$ type in the villages MAT, $\mathrm{CHU}$, and $\mathrm{FAR}$, while $\mathrm{Ca}-\mathrm{HCO}_{3}$ type in HAJ and SHA, indicating that the anthropogenic activity does not directly affect releasing As into the groundwaters of this area. Also, the high As groundwaters are rather diluted among the studied groundwater. It is suggested that the As is released from the sediments at the early stage of reaction between the infiltrating groundwater and minerals of the flowing paths.

\subsection{Mineralogy and sequential extracted chemistry}

As concentration had positive relationship to the XRD intensities of clay minerals, chlorite and mica, suggesting that certain amounts of As was adsorbed onto the fine fractions of aquifer sediments.

Two sets of core sediments taken from HAJ down to $23 \mathrm{~m}$ depths were analyzed by sequential chemical extraction. The total As concentration of the whole core sediments was within 2 and $8 \mathrm{ppm}$. Mobile compounds, categorized as weakly adsorbed, reducible and oxidizable fractions were 20 to $60 \%$ of the total As of the sediments. It is notable that the reducible phase, which means the As strongly adsorbed onto and/or fixed in Fe-oxyhydroxides and Mn-oxides, occupies the most abundant host phase of the As, although the mobile phases of As is smaller in the uppermost sediments than the lower ones. Considering increasing As concentration with increasing $\mathrm{pH}$, the level of As of the studied groundwater would be controlled by desorption from the Fe-oxyhydroxides and/or clay fractions

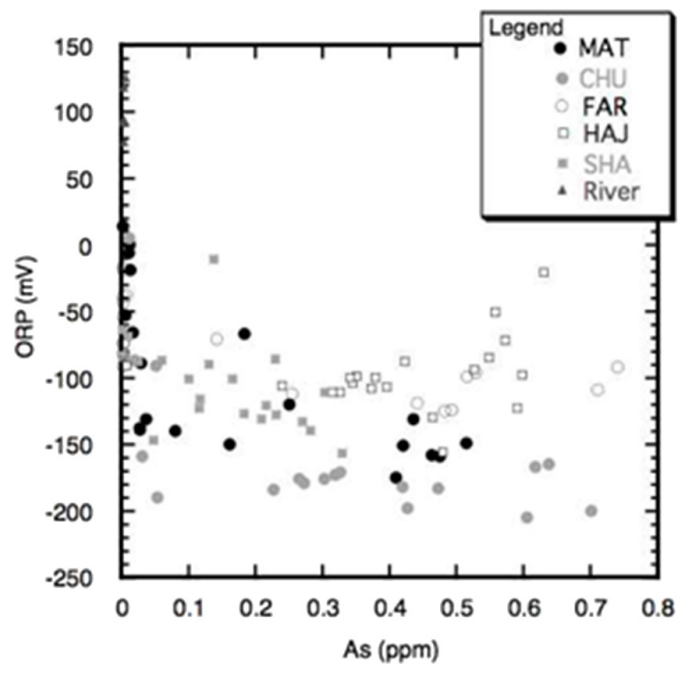

Figure 2. Relationship between As concentration and ORP of groundwaters from Chandpur and its surroundings.

with progressing chemical weathering. Dissolution of the Fe-oxyhydroxides as a host of As may follow the desorption.

\section{CONCLUSIONS}

Studied groundwaters would contain high As, which was released from the sediments via infiltration of river and/or local meteoric water to promote the chemical weathering and resulting increasing $\mathrm{pH}$ to desorb As from the Fe-oxyhydroxides and/or clay minerals as hosts of As in the studied groundwater aquifers. Chemical weathering must be an important mechanism of As releasing into the groundwater in the Neogene aquifers of the studied area.

\section{ACKNOWLEDGEMENTS}

We thank to T. Shimonaka and K. Okazaki, Osaka City University, and Drs. A. Marui and M. Ono, AIST, who supported the water analyses.

\section{REFERENCE}

Rauret, G., López-Sánchez, J.F., Sahuquillo, A., Rubio R., Davidson, C., Ure, A. \& Quevauvillerc, Ph. 1999. Improvement of the BCR three step sequential extraction procedure prior to the certification of new sediment and soil reference materials. J. Environ. Monit. 1: 57-61. 


\title{
Groundwater arsenic distribution reconnaissance survey in Myanmar
}

\author{
L.A. Richards, G.P. Pincetti Zúñiga \& D.A. Polya \\ School of Earth, Atmospheric and Environmental Sciences and Williamson Research Centre for Molecular \\ Environmental Science, University of Manchester, Manchester, UK
}

\begin{abstract}
Dangerous arsenic concentrations in shallow groundwaters threaten the health and livelihoods of millions of people, particularly in South/Southeast Asia. However, the scope and magnitude of groundwater arsenic hazard is relatively poorly understood in Myanmar as compared to neighboring counties. We undertook a groundwater quality survey across five (hydro)geologically distinct regions of Myanmar, and initial field results indicate elevated arsenic in a number of samples including in areas where previously modeled probability of arsenic concentrations exceeding the provisional WHO guideline was low. Data validation and interpretation of possible geochemical and/or hydrological controls are the subject of ongoing investigation.
\end{abstract}

\section{INTRODUCTION}

Millions of people in South/Southeast Asia are chronically exposed to dangerous concentrations of geogenic arsenic in groundwater (e.g. Charlet \& Polya, 2006; Smedley \& Kinniburgh, 2002 and refs within). Although the scope and magnitude of this problem is reasonably well defined in some areas particularly in countries such as Bangladesh, India, Cambodia, Vietnam and China, widespread international understanding of the distribution of arsenic in Myanmar is much more limited and in some cases is restricted to predictive models based on surface geological parameters (Amini et al., 2008; Winkel et al., 2008), despite elevated levels of arsenic being confirmed in the Ayeyarwady Basin (van Geen et al., 2014). We aim to improve the understanding of arsenic distribution in a cross-country groundwater quality survey incorporating five geologically distinct regions within Myanmar.

\section{METHODS/EXPERIMENTAL}

\subsection{Field area}

Field sites $(\mathrm{n}=85)$ were located across Myanmar and were broadly based around Maubin $(n=13)$, Thongwa $(\mathrm{n}=11)$, Loikaw $(\mathrm{n}=18)$, Kalay $(\mathrm{n}=23)$ and Mandalay $(\mathrm{n}=20)$ (Fig. 1). General sampling regions were selected on the basis of (i) encompassing different predicted arsenic hazard categories (Winkel et al., 2008); (ii) encompassing areas of different (hydro)-geological characteristics; (iii) collaboration with local partners. Specific sampling locations within each region were selected with the input of local partners. In brief, the geology is dominated by recent alluvial deposits in the Ayeyarwady basin, Permian limestones in the Shan Plateau, and Cretaceous flysch sedimentary sequences in the Indo-Burman Ranges (Bender, 1983).

\subsection{Sample collection and analysis}

Groundwater samples $(n=85)$ were collected from existing tube wells and dug wells in December 2017 during which in-situ analysis of parameters such as $\mathrm{pH}, E h$, temperature, electrical conductivity, alkalinity, sulfide, ammonium, nitrate, nitrite and fluoride were conducted using methods adapted from previous studies in Cambodia (cf. Richards et al., 2017). Initial field measurements of arsenic were made visually using the ITS Econo-Quick arsenic kit (van Geen et al., 2014).

\section{RESULTS AND DISCUSSION}

Groundwater arsenic, as measured visually with field kits, ranged from 0-500 $\mathrm{g} \mathrm{L}^{-1}$ (Fig. 2), with the highest concentrations observed in the Ayeyarwady Basin as previously predicted by arsenic hazard models (Winkel et al., 2008) and confirmed by field measurements (van Geen et al., 2014) undertaken within the same region but in different specific areas. Elevated arsenic was also observed in other areas, including the area surrounding Loikaw, an area which was not predicted to be likely to have elevated arsenic by previous predictive models (Winkel et al., 2008). Overall $42 \%$ of samples collected ( 36 of 85 ) estimated arsenic $\geq 10 \mu \mathrm{g} \mathrm{L}^{-1}$, including in areas not encompassed by previous arsenic hazard maps, which suggests that it is possible that higher populations and/or additional geographical areas may be at risk from elevated arsenic than previously predicted. Confirming field measurements and linking results with other groundwater geochemical parameters (e.g. Fe, $\mathrm{HCO}_{3}^{-}$, Eh, $\mathrm{pH}$, etc.) 


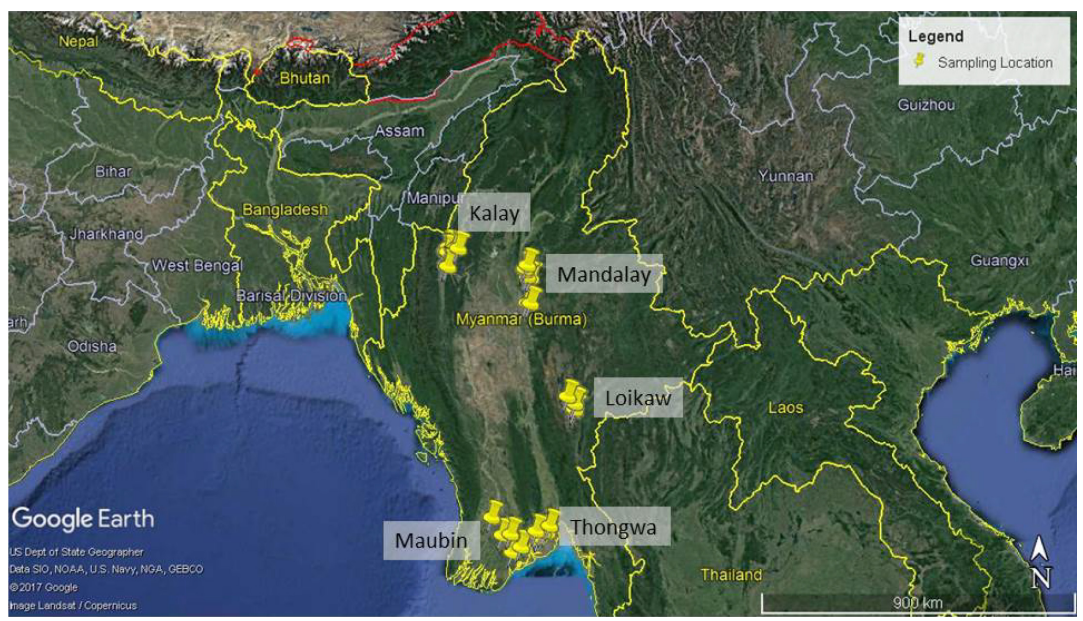

Figure 1. Map showing sampling sites $(\mathrm{n}=85)$ from general field areas based around Maubin $(\mathrm{n}=13)$, Thongwa $(\mathrm{n}=11)$, Loikaw $(n=18)$, Kalay $(n=23)$, and Mandalay $(n=20)$; map adapted from Google Earth with attribution as shown. Samples with arsenic $\geq 50 \mu \mathrm{gL}^{-1}(\mathrm{n}=9)$ were located in the Maubin $(\mathrm{n}=4)$, Thongwa $(\mathrm{n}=3)$ and Loikaw $(\mathrm{n}=2)$ sampling areas.

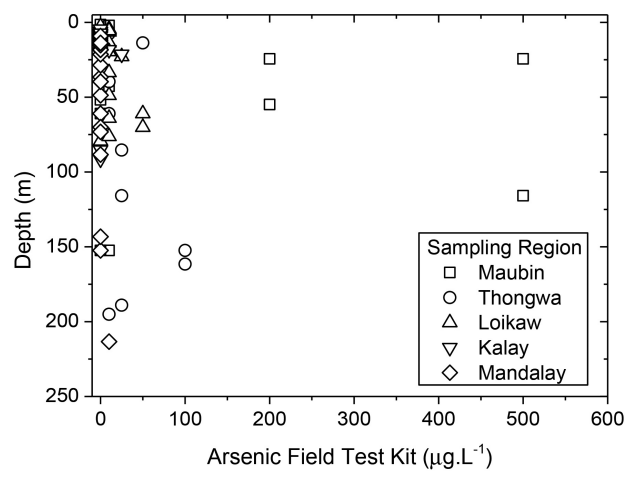

Figure 2. Arsenic (ITS Econo Quick Visual test kit) versus reported depth for each sampling region. Note test kit reports a semi-quantitative range of values assessed visually.

as well as potential (hydro)-geological controls is the subject of ongoing work.

\section{CONCLUSIONS}

A cross-country groundwater quality survey indicates that elevated levels of arsenic are likely to occur in several distinct, previously under-studied regions of Myanmar. Results will be validated by further, laboratory-based analysis including analysis of major and trace elements and arsenic speciation.

\section{ACKNOWLEDGEMENTS}

This research was supported by the Leverhulme Trust (ECF2015-657 to LR), with additional support from an Engineering and Physical Sciences Research Council Improving Diversity Award (to LR, Tun, Gibson and DP). We are very grateful to substantial support especially from Yin Min Tun (eTekkatho Digital Library), project partners and field assistants from Dagon University, Maubin University, Loikaw University, Kalay University and Mandalay University, Helen Downie (University of Manchester) and local authorities and landowners.

\section{REFERENCES}

Amini, M., Abbaspour, K.M., Berg, M., Winkel, L., Hug, S.F., Hoehn, E., Yang, H. \& Johnson, A. 2008. Statistical modeling of global geogenic arsenic contamination in groundwater. Environ. Sci. Technol. 42: 3669-3675.

Bender, F. 1983. Geology of Burma: Gebrüder Borntraeger.

Charlet, L. \& Polya, D.A. 2006. Arsenic in shallow, reducing groundwaters in southern Asia: An environmental health disaster. Elements 2: 91-96.

Richards, L.A., Magnone, D., Sovann, C., Kong, C., Uhlemann, S., Kuras, O., van Dongen, B.E., Ballentine, C.J. \& Polya, D.A. 2017. High resolution profile of inorganic aqueous geochemistry and key redox zones in an arsenic bearing aquifer in Cambodia. Sci. Total Environ. 590-591: 540-553.

Smedley, P.L. \& Kinniburgh, D.G. 2002. A review of the source, behaviour and distribution of arsenic in natural waters. Appl. Geochem. 17(5): 517-568.

van Geen, A., Win, K.H., Zaw, T., Naing, W., Mey, J.I., \& Mallioux, B. 2014. Confirmation of elevated arsenic levels in groundwater of Myanmar. Sci. Total Environ. 478: 21-24.

Winkel, L., Berg, M., Amini, M., Hug, S.J. \& Johnson, C.A. 2008. Predicting groundwaters arsenic contamination in Southeast Asia from surface parameters. Nat. Geosci. 1: 536-542. 


\title{
Potential arsenic contamination in drinking water sources of Tanzania and its link with local geology
}

\author{
J. Ijumulana ${ }^{1,2}$, F. Mtalo $^{1} \&$ P. Bhattacharya ${ }^{2}$ \\ ${ }^{1}$ DAFWAT Research Group, Department of Water Resources Engineering, College of Engineering and Technology, \\ University of Dar es Salaam, Dar es Salaam, Tanzania \\ ${ }^{2}$ KTH-International Groundwater Arsenic Research Group, Department of Sustainable Development, \\ Environmental Science and Engineering, KTH Royal Institute of Technology, Stockholm, Sweden
}

\begin{abstract}
Recent studies on arsenic (As) occurrence particularly in African waters show that several sources of drinking water have elevated concentrations above national and international guidelines. In Tanzania, elevated concentrations of As above the WHO guideline $\left(10 \mu \mathrm{g} \mathrm{L}^{-1}\right)$ in Lake Victoria Gold fields is emerging as a threat to public health depending on groundwater and surface water as drinking water sources. In this study, spatial statistics and GIS tools have been used to delineate the relationship between As occurrence and local geological settings. Among the 12 mapped local geological units, the most targeted aquifers for potable water are characterized by granitoids, migmatite, mafic and ultramafic meta-sediments ( $\sim 50 \%$ of water points). The probability of having As levels above the WHO guideline was 0.71 and 0.33 for surface water and groundwater systems respectively.
\end{abstract}

\section{INTRODUCTION}

High levels of arsenic (As) have been reported both in surface water and groundwater in several African countries (Ahoulé et al., 2015). The source, distribution and mobilization of As in aqueous environment differs by country and within same country differs by location and are associated with either geogenic or anthropogenic processes. Elevated concentrations of As has been reported in the northern part of Tanzania, particularly around the Lake Victoria Goldfields (LVGF) (Mnali, 2001; Lucca et al., 2017) within Lake Victoria Basin (LVB). In the LVGF, large spatial variability of As occurrence has been identified in terms of concentration as well as speciation which hinders meaningful conclusion on its fate based on the available database (Kassenga \& Mato, 2008). The present study aims to investigate: i) the effects of local geological settings on the distribution of As and its concentrations in the drinking water sources; ii) the effects of climate on the variability of As in water sources; and iii) understand the probable links of the adverse health outcomes (viz. cancer cases) due to long term ingestion of inorganic As in drinking water sources in the region. In this abstracts results on spatial variability of arsenic occurrence with respect to local geological setting are presented.

\section{MATERIALS AND METHODS}

\subsection{Study area}

Lake Victoria Basin, Tanzanian part, is one of the 9 river basins in Tanzania mainland covering area of $119,442 \mathrm{~km}^{2}$. The region has little seasonal variation but the eastern sections where Mara region, the study area lies, average only $750-1000 \mathrm{~mm}$ of rain. Favourable climatic conditions for agriculture and livestock and the abundance of natural resources have supported the livlihood of the rural population of over 35 million people (Lucca et al., 2017). The geology of the Tanzanian LBV consists of Archean granitoids-greenstone belts hosted in the Tanzanian Craton. More than $80 \%$ of rural population depends on groundwater resources for various use.

\subsection{Assessment of drinking water supply points in Lake Victoria Basin with respect to local geology}

More than $80 \%$ of rural population in LVB depend on groundwater resources abstracted through boreholes, springs, shallow wells and deep wells. Approximately $50 \%$ of abstraction points target aquifers composed of migmatite-granitoid-metasediment complex, metasediments ( $\sim 22 \%)$, sandy, gravelly, silty sediments $(\sim 10 \%)$, mafic volcanics, meta-basalts, phyllite-greenstone belt with BIF ( $\sim 9 \%)$. The remaining $10 \%$ of groundwater abstraction points target aquifers characterized by the 8 remaining local geological units.

\subsection{Water sampling and laboratory analysis}

Water sampling was carried out at the end of dry season during October 2016. A total of 29 water samples were collected, of which 18 samples were taken from groundwater sources and 11 samples from surface 


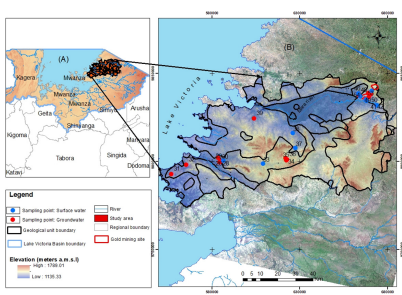

Figure 1. Study area (A) and water sampling locations (B).

water sources were collected (Fig. 1). The physiochemical parameters such as, $\mathrm{pH}$, temperature $(\mathrm{T})$, electrical conductivity (EC), redox potential (Eh) and elevation $(\mathrm{H})$ were measured in the field. Major anions were analyzed by ion chromatography (IC Dionex DX-120) in the Land and Water Resources Engineering laboratory at KTH Royal Institute of Technology. Major cations were determined by inductively coupled plasma-optical emission spectrometry (ICP-OES) at Linköping University in the Department of Thematic Studies.

\subsection{Creation of spatial database and data analysis}

ArcGIS software was used to create spatial database comprising the location and description of each water sample, physio-chemical parameters and major ions and As. The data analysis part involved calculating and mapping of summary statistics, i.e. minimum, maximum, average, and standard deviation.

\section{RESULTS AND DISCUSSION}

\subsection{Spatial exploration of water quality parameters with local geological settings}

The collected water samples were from abstraction points targeting aquifers with following sediment types: i) predominantly alluvial and eluvial sediments (aQ) with slightly alkaline $\mathrm{pH}$ (7.4) and high Eh $($ mean $+416 \mathrm{mV})$; ii) migmatite-granitoid-metasediment complex (miNA) with neutral $\mathrm{pH}$ (7.0) and higher Eh $(356.4 \mathrm{mV}$ mean); and iii) volcanosedimentary complex-Greenstone Belt with banded iron formation (BIF) with approximately neutral $\mathrm{pH}$ (6.9). The higher EC values between 715 and $843 \mu \mathrm{S} / \mathrm{cm}$ indicate that aquifer sediments originate from the parent rocks in Tanzanian Craton. Similarly, the higher mean Eh values between $356-416 \mathrm{mV}$ suggest an oxidizing environment in all geologic units.

\subsection{Probability of occurrence of arsenic contamination in groundwater}

The probability of having contaminated aquifers was calculated based on number of samples with arsenic concentrations exceeding WHO guideline value constrained by local geologic units. Figure 2 shows a probability map of potential arsenic contaminated aquifers.

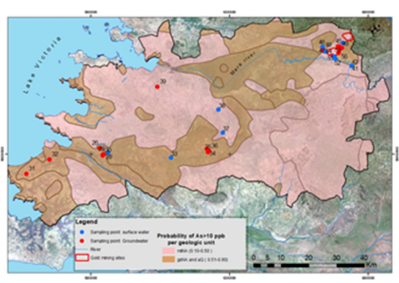

Figure 2. Probability map of arsenic contaminated drinking water sources in Lake Victoria Gold Fields in Mara region.

The most probable aquifers with As levels exceeding $10 \mu \mathrm{g} \mathrm{L}^{-1}$ are found in the lithologic groups aQ and gsNA rocks/sediments (50-90\%). Aquifers in the migmatite-granitoid-meta-sediment complex (miNA) indicate comparatively less likelihood of elevated levels of As in well water. However, this is just a preliminary observation based on the small sample size, and work is currently in progress to link the overall hydrogeochemical characteristics, such as major ions, As and other trace elements with the mapped geological units.

\section{CONCLUSIONS AND RECOMMENDATIONS}

Arsenic contamination in Lake Victoria Basin is a really problem in drinking water sources. The most targeted aquifers composed of migmatite-granitoidmetasediment complex and metasediments seem to have high levels of arsenic exceeding WHO guideline. The drilling practice during potable water supply should consider the type of geological units and sediments to avoid continual exposure to arsenic toxicity among Lake Victoria Basin communities. The behaviour of excess arsenic needs to be investigated with respect to seasonal variations and depth.

\section{ACKNOWLEDGEMENTS}

We acknowledge the Swedish International Development Cooperation Agency (Sida) for supporting the DAFWAT program (Contribution: 51170072).

\section{REFERENCES}

Ahoulé, D.G., Lalanne, F., Mendret, J., Brosillon, S. \& Maïga, A.H. 2015. Arsenic in African waters: a review. Wat. Air Soil Poll. 226(9): 302.

Kassenga, G.R. \& Mato, R.R. 2008. Arsenic contamination levels in drinking water sources in mining areas in Lake Victoria Basin, Tanzania, and its removal using stabilized ferralsols. Int. J. Biol. Chem. Sci. 2(4): 389-400.

Lucca, E. 2017. Geochemical Investigation of Arsenic in Drinking Water Sources in Proximity of Gold Mining Areas in the Lake Victoria Basin, in Tanzania. MSc Thesis, TRITA SEED-EX 2017:25, KTH Royal Institute of Technology, Sweden, 98p.

Mnali, S. 2001. Assessment of heavy metal pollution in the Lupa gold field, SW Tanzania. Tanzania J. Sci. 27(2): 15-22. 


\title{
Spatial variability of trace elements with Moran's I Analysis for shallow groundwater quality in the Lower Katari Basin, Bolivian Altiplano
}

\author{
I. Quino ${ }^{1,2}$, O. Ramos ${ }^{1}$, M. Ormachea ${ }^{1}$, J. Quintanilla ${ }^{3}$ \& P. Bhattacharya ${ }^{2,3}$ \\ ${ }^{1}$ Laboratorio de Hidroquímica, Instituto de Investigaciones Químicas, Universidad Mayor de San Andrés, \\ La Paz, Bolivia \\ ${ }^{2}$ KTH-International Groundwater Arsenic Research Group, Department of Sustainable Development, \\ Environmental Science and Engineering, KTH Royal Institute of Technology, Stockholm, Sweden \\ ${ }^{3}$ International Center for Applied Climate Science, University of Southern Queensland, Toowoomba, \\ Queensland, Australia
}

\begin{abstract}
The southeastern part of the Titicaca Lake near the Cohana Bay in the Bolivian Altiplano, has environmental problems caused mainly by urban and industrial wastes upstream of the Katari Basin and by natural geological conditions. This environmental condition has generated an increase in the concentrations of some trace elements in the groundwater. The Moran's I statistic was used with LISA (Local Indicators of Spatial Association) method to know the spatial autocorrelation and the spatial variability of As, Sb, B, Al, Mn and F. Arsenic and antimony are the main pollutants due to natural geological conditions and boron due to the anthropogenic activities. Almost half of all the shallow groundwater samples exceeded the WHO and NB-512 guideline values mainly for antimony, boron and arsenic, whereby the spatial distribution of these trace elements in groundwater raises a significant concern about drinking water quality.
\end{abstract}

\section{INTRODUCTION}

Recent studies indicate that the Cohana Bay (Titicaca Lake) has environmental problems caused mainly by urban and industrial wastes upstream of the Lower Katari Basin (Fig. 1) and by natural geological conditions. The study area (91 communities) is located in the southeastern part of the Titicaca Lake, in the Bolivian Altiplano, with an area of $484 \mathrm{~km}^{2}$ (Fig. 1). Drinking water is extracted from excavated wells $(<10 \mathrm{~m}$ depth), these wells are also used for irrigation and animal consumption. The objective of this paper is to find the spatial variability using spatial autocorrelation of trace elements (As, Sb, B, Al, Mn and F), considering the hidrogeochemistry, the geographic information systems tools and the water quality of community consumption wells.

\section{METHODS/EXPERIMENTAL}

\subsection{Sampling and laboratory work}

Sampling was carried out during May 2015, 32 groundwater samples ( 32 communities) and 6 surface water samples were collected. The physicochemical parameters, $\mathrm{pH}$, temperature $(\mathrm{T})$, electrical conductivity (EC), redox potential (Eh) and total dissolved solid (TDS) were measured in the field with a multiparameter HANNA - HI 9828. Major anions were analyzed by Dionex ion chromatograph (ICS 1100) at the Environmental Chemistry Laboratory at Universidad Mayor

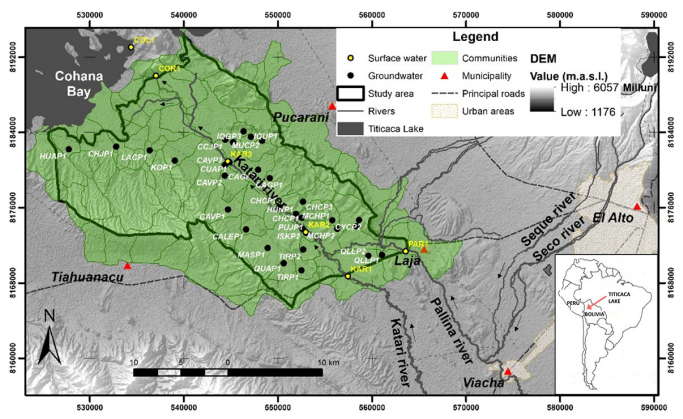

Figure 1. Study area and sampling points.

de San Andrés in La Paz Bolivia. Major cations and TEs were determined by inductively coupled plasmamass spectrometry at the Mineral Laboratories Canada of the Bureau Veritas Commodities Canada Ltd. in Vancouver Canada.

\subsection{Data analysis}

The Aquachem software (4.0.264 Waterloo Hydrogeologic Inc, 2003) was used to evaluate the analyses results for water samples and the type of water was determined. With the 32 sampling points, an interpolation was made for each TE using the deterministic method Inverse Distance Weighted (IDW). The interpolations were classified, to each of the $91 \mathrm{com}$ munities were assigned mean values according to the 


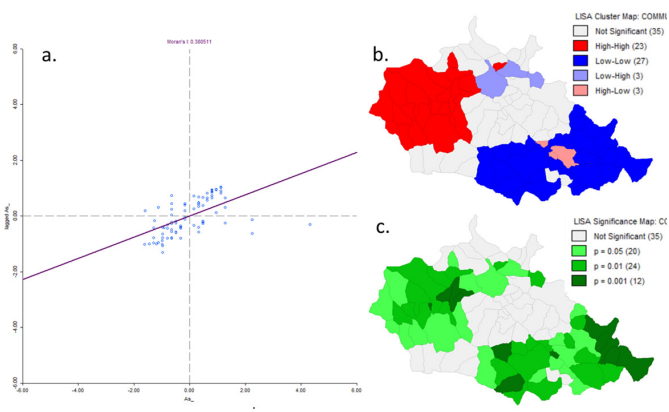

Figure 2. Global Moran's I statistiscal test (a), BiLISA Cluster Map (b) and BiLISA Significance Map (c) for As.

classified interpolation made. The percentage difference (PD) between the measured value and the value predicted by the interpolation was made for the 32 communities where the groundwater samples were taken. All these procedures were done in the ArcGIS 10.2.2 software.

The Moran's I statistic was used with LISA (Local Indicators of Spatial Association) method to know the spatial autocorrelation (SA) of each element. The global spatial dependence analysis (Global Moran's I statistiscal test), the local spatial dependence (BiLISA Cluster Map) and the significant spatial test (BiLISA Significance Map) were made in the GeoDa 1.12.01 software.

\section{RESULTS AND DISCUSSION}

\subsection{General hydrochemical characteristics}

The $\mathrm{pH}$ is slightly alkaline (7.8 mean), the Eh suggesting a moderately oxidizing environment $(189.3 \mathrm{mV}$ mean). High EC (279-7984 $\mu \mathrm{S} \mathrm{cm}^{-1}$ ) due to the lacustrine origin of sediments. $12.5 \%$ of the samples are of $\mathrm{Ca}-\mathrm{HCO}_{3}$ water type. $87.5 \%$ of the groundwater samples exceed the Bolivian regulation (NB-512) for $\mathrm{Sb}$ $\left(5 \mu \mathrm{g} \mathrm{L}^{-1}\right), 56.2 \%$ for $\mathrm{B}\left(300 \mu \mathrm{g} \mathrm{L}^{-1}\right)$ and $50 \%$ for $\mathrm{As}$ considering the WHO guideline values $\left(10 \mu \mathrm{g} \mathrm{L}^{-1}\right)$.

\subsection{Spatial variability of the trace elements}

The global spatial dependence analysis (Fig. 2a) gave values of Moran's I for As (0.38), Al (0.45), B (0.42), F (0.23), $\mathrm{Mn}(0.22)$ and $\mathrm{Sb}(0.19)$, these values indicate a positive autocorrelation and statistically significant for all cases, the p-value is 0.001 for the six cases. In the Cluster Map (Fig. 2b), spatial association statistic of Moran's I are presented, there are 23 High-high type communities, which are surrounded by communities with high concentration for $\mathrm{As}, 17$ for $\mathrm{Al}, 17$ for $\mathrm{Mn}, 16$ for $\mathrm{B}, 16$ for $\mathrm{F}$ and 13 for $\mathrm{Sb}$, there are also 27 communities of Low-low type, which are communities with low As concentrations that are surrounded by other communities of low concentration of As, for $\mathrm{B}$ are 27, 24 for $\mathrm{Mn}, 17$ for $\mathrm{F}, 16$ for $\mathrm{Al}$, and 15 for $\mathrm{Sb}$. In the significance map for As (Fig. 2c), the probabilities of the relationship of contiguity (adjacency) occuring in a random way are shown. 56 significant are highlighted for As, 52 for B, 46 for Mn, 39 for F, 33 for $\mathrm{Al}$ and 33 for $\mathrm{Sb}$. With a value that indicates an error probability of $0.001,0.01$ and 0.05 for all cases, in the rest the white color predominates indicating the absence of significance.

The spatial distribution of As shows a positive SA to the northwest (Cohana Bay) of the study area (Fig. 2b). The interaction between surface water and groundwater and the location of the wells around the volcanic formations and their dissolution could be the natural source of As. The B has a positive SA to the southeast of the study area, where the confluence of the Pallina and Katari rivers (alluvial, colluvio - fluvial deposits) is found. The aquifers are superficial and due to the agricultural activity present in the area could develop rapid processes of anthropogenic contamination (Molina et al., 2001). The Sb shows high spatial autocorrelation northeast of the study area where Devonian rocks exist as part of the Bolivian antimony belt of the Eastern Cordillera (Arce-Burgoa \& Goldfarb, 2009), this could explain the presence of $\mathrm{Sb}$ as the result mainly from weathering of carbonate rocks (Seal et al., 2017) of the Devonian.

\section{CONCLUSIONS}

The occurrences of $\mathrm{Al}, \mathrm{B}, \mathrm{As}, \mathrm{F}$ and $\mathrm{Sb}$ are not random and form significant groups in space. More than $50 \%$ of the samples exceed the NB-512 and WHO guidelines for $\mathrm{Sb}, \mathrm{B}$ and $\mathrm{As} . \mathrm{Sb}$ and $\mathrm{As}$ are the main pollutants due to natural geological conditions and boron due to the anthropogenic activities. The spatial distribution of dissolved $\mathrm{Sb}, \mathrm{B}$ and As concentrations in groundwater raises a significant concern about drinking water quality.

\section{ACKNOWLEDGEMENTS}

We are thankful to the Swedish International Development Cooperation Agency (Sida) for the SwedenBolivia cooperation program on research capacity development through Contribution: 75000553.

\section{REFERENCES}

Arce-Burgoa, O.R. \& Goldfarb, R.J. 2009. Metallogeny of Bolivia: Society of Economic Geologists Newsletter, 79(1): 8-15.

Molina, S.L., Sanchez, M.F., Pulido, B.A. \& Vallejos, I.A. 2001. Consideraciones sobre el boro en las aguas subterraneas del Campo de Dalias (Almeria). Geogaceta, 29: 79-82.

Seal, R.R., II, Schulz, K.J. DeYoung, J.H., Jr., with contributions from David M. Sutphin, Lawrence J. Drew, James F. Carlin, Jr., \& Byron R. Berger, 2017, Antimony, chap. C of Schulz, K.J., DeYoung, J.H., Jr., Seal, R.R., II, \& Bradley, D.C., eds., Critical mineral resources of the United States-Economic and environmental geology and prospects for future supply: U.S. Geological Survey Professional Paper 1802, p. C1-C17. 


\title{
Influence of hydrothermal fluids enriched in As and F on the chemistry of groundwaters of the Duero Basin, Spain
}

\author{
E. Giménez-Forcada ${ }^{1}$, S. Timón-Sánchez ${ }^{1} \&$ M. Vega-Alegre ${ }^{2}$ \\ ${ }^{1}$ Instituto Geológico y Minero de España - IGME, Salamanca, Spain \\ ${ }^{2}$ Departamento de Química Analitica, Universidad de Valladolid - UVA, Valladolid, Spain
}

\begin{abstract}
Chemical and isotopic data of groundwaters from the south edge of the Duero Basin have been interpreted by multivariate statistical analysis including HCA and PCA. The results suggest that waters enriched in arsenic, fluoride and other associated trace elements are alkaline $\mathrm{Na}-\mathrm{HCO}_{3}$ cold-hydrothermal waters, flowing through main faults of the basement.
\end{abstract}

\section{INTRODUCTION}

In some areas of the southern area of the Duero Basin (DB), Spain, naturally occurring arsenic and associated trace elements are present in concentrations exceeding the limits established for drinkable water. The study area is located in the Duero Basin where Cenozoic sediments from the basin contrast with the metasedimentary and igneous rocks of the Spanish Central System (SCS) (Fig. 1).

In this range, As and $F$ are present in several rock-forming minerals from the crystalline bedrock. Arsenic is identified in sulfides (arsenopyrite), oxides (magnetite, ilmenite) and ferromagnesian silicates (olivine, pyroxene). Meanwhile, fluorine occurs in primary minerals as biotites, amphiboles, topaz and apatite. Both elements and other trace elements (Mo, $\mathrm{V}, \mathrm{Cr}$ and $\mathrm{U}$ ) constitute a suite of incompatible elements, which have difficulty in entering lattice sites of the minerals during the fractional crystallization of magma, and therefore are concentrated in the fluid phase.

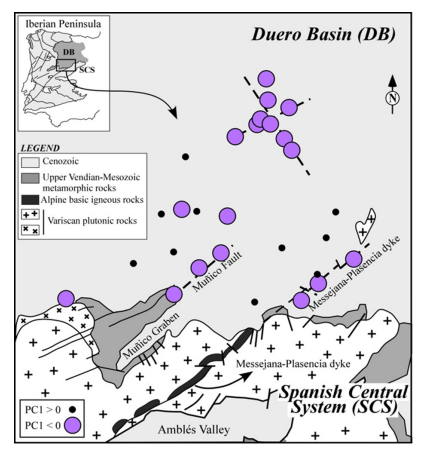

Figure 1. Location of the study area and distribution of PC1 scores.
The aim of this research is to gain knowledge of the geological environment controlling As and $\mathrm{F}$ contents in groundwaters of the south edge of the $\mathrm{DB}$, using multivariate statistical tools as Hierarchical Cluster Analyses (HCA) and Principal Components Analyses (PCA) for data interpretation.

\section{METHODS}

Twenty-one physico-chemical parameters, including temperature, $\mathrm{pH}$, electrical conductivity, redox potential, alkalinity, major anions and cations, natural isotopes and trace elements (As and F, but also $\mathrm{Cr}, \mathrm{Mo}, \mathrm{V}$ and $\mathrm{U}$ ), were determined in 34 groundwater samples collected from springs, wells and boreholes located in the study area (Avila province, Spain).

Water temperature, $\mathrm{pH}$, electrical conductivity (EC, $25^{\circ} \mathrm{C}$ ), and oxidation-reduction potential, ORP, were recorded on site. The ORP measurements were corrected for temperature and referenced to the SHE potential. Groundwater samples were filtered $(0.45 \mu \mathrm{m})$ in situ into polyethylene bottles. Those collected for cation analysis were acidified to $1 \% \mathrm{v} / \mathrm{v}$ with $\mathrm{HNO}_{3}(65 \%)$. Major anions and cations and trace elements were determined in the IGME laboratories by standard methods described elsewhere (GiménezForcada \& Smedley, 2014). Electrical charge imbalances were, in all cases, less than $3 \%$.

\section{RESULTS AND DISCUSSION}

The HFE-Diagram (Fig. 2) shows that samples with the highest concentrations in arsenic and fluoride correspond mainly to $\mathrm{Na}-\mathrm{HCO}_{3}$ waters.

Correlations of As with $\mathrm{F}$ and other hydrochemical variables were uncovered by HCA and PCA. HCA dendrogram shows two main families of variables (Fig. 3). One linked to major chemistry and those associated 


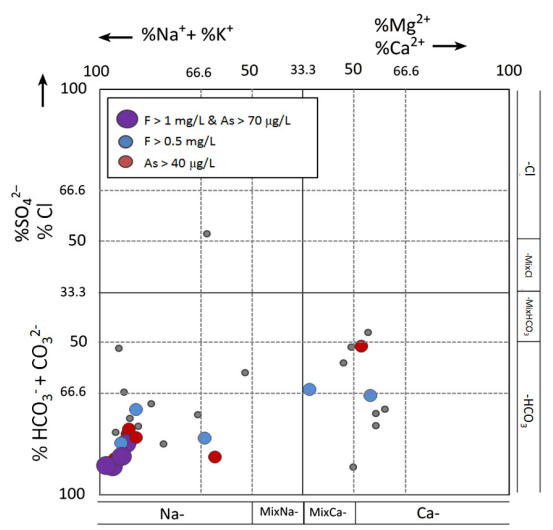

Figure 2. Representation of water samples in the HFE diagram (Giménez-Forcada \& Sánchez 2014), modified.

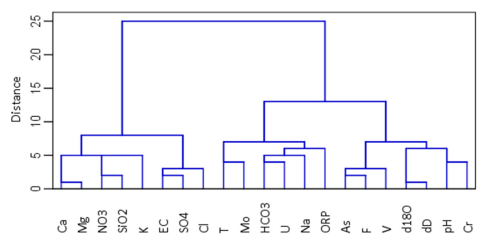

Figure 3. Dendrogram of chemical parameters obtained by HCA using the Ward linkage method.

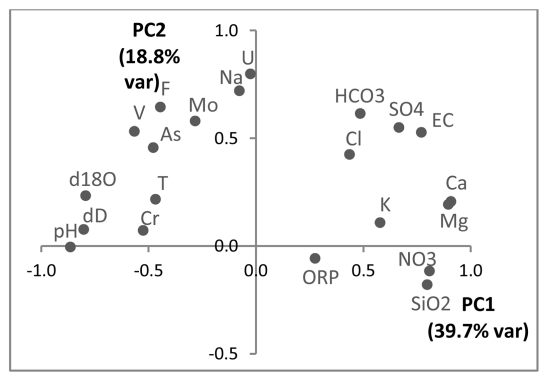

Figure 4. Loadings of the first two principal components obtained by PCA.

with $\mathrm{NaHCO}_{3}$ flows. PCA corroborates this association (Fig. 4). In fact, the first principal component, PC1 (which explains the $39.7 \%$ of variance) differences clearly the two main groups referred. These correlations suggest that there are alkaline $\mathrm{Na}-\mathrm{HCO}_{3}$ water flows feeding the basin. These waters, enriched in As, $\mathrm{F}, \mathrm{V}, \mathrm{Cr}, \mathrm{U}$ and $\mathrm{Mo}$ are characterized by a moderate temperature (cold-hydrothermal waters, $18^{\circ} \mathrm{C}-19^{\circ} \mathrm{C}$ ) and a singular signature of $\delta^{18} \mathrm{O}$ and $\delta^{2} \mathrm{H}$ (the most negative values of all both parameters).

The correlation between As and other trace elements suggests they have similar geogenic sources and are mobile under similar hydrogeochemical conditions. These sources include igneous-metamorphic bedrocks, mineral occurrences as well as geothermal fluids.
Scores of samples on $\mathrm{PC} 1$ have been represented in Figure 4 . The highest values are associated to relevant faults and their prolongation in the basin, showing a distribution of As, F and other trace elements controlled by structural features.

Previous works in the area have established the structural control of As distribution in $\mathrm{DB}$, and the correspondence of high contents of F, B and Mo with the highest concentration of As in alkaline $\mathrm{Na}-\mathrm{HCO}_{3}$ groundwaters (Giménez-Forcada \& Smedley, 2014).

Fluids flowing through major faults of the DB basement could be a relevant source of As in the study area. Therefore, it seems likely that the occurrence of As and associated trace elements derives at least partially from enriched deep hydrothermal fluids. Arsenic associated with geothermal waters has been reported in several parts of the world (Smedley \& Kinniburgh, 2002), and $F$ is recognized as a mobile element under high-temperature conditions and is abundant in hydrothermal solutions (Edmunds \& Smedley, 2013).

Without neglecting other sources and processes, the influence of cold-hydrothermal waters enriched in several trace elements and associated with the fissured aquifers from SCS, which in turn form the basement of the DB, could be relevant.

\section{CONCLUSIONS}

The high concentrations of As and $\mathrm{F}$ in groundwaters from the DB south bank could be explained considering inputs of hydrothermal fluids flowing through main faults of the basement. This process does not exclude other possible sources as water-rock interaction processes.

\section{ACKNOWLEDGEMENTS}

This work was supported by the Geological Survey of Spain (IGME). HidroGeoTox (Research Project Ref. IGME-2303) and by the Junta de Castilla y León (Research Project Ref. VA291U14/Ref. IGME $2474-$ As Cega).

\section{REFERENCES}

Edmunds, W.M. \& Smedley, P.L. 2013. Fluoride in natural waters. In: O. Selinus, (ed.) Essentials of Medical Geology, Second Edition. Springer, 311-336p.

Giménez-Forcada, E. \& Sánchez San Román, F.J. 2014. An excel macro to plot the HFE-Diagram to identify sea water intrusion phases. Groundwater 53(5): 819-824.

Giménez-Forcada, E. \& Smedley, P.L. 2014. Geological factors controlling occurrence and distribution of arsenic in groundwaters from the southern margin of the Duero Basin, Spain. Environ. Geochem. Hlth. 36(6):1029-1047.

Smedley, P.L. \& Kinniburgh, D.G. 2002. A review of the source, behaviour distribution of arsenic in natural waters. Appl. Geochem. 17: 517-568. 


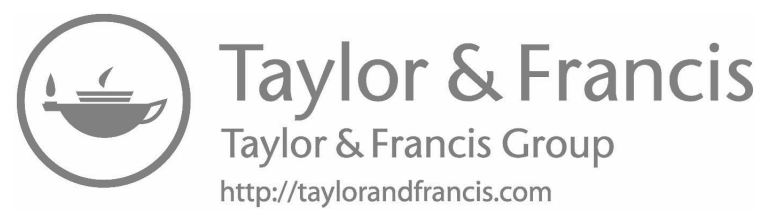


1.2 Origin and reactivity of organic matter in high arsenic groundwater systems 


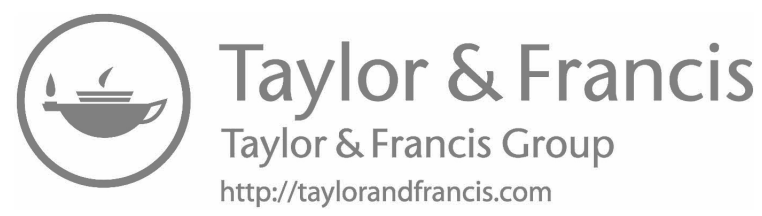




\title{
Arsenic methylation and its relationship to abundance and diversity of arsM genes in composting manure
}

\author{
W.W. Zhai, X.J. Tang \& J.M. Xu \\ Institute of Soil and Water Resources and Environmental Science, College of Environmental and Resource Sciences, \\ Zhejiang Provincial Key Laboratory of Agricultural Resources and Environment, Zhejiang University, Hangzhou, \\ P.R. China
}

\begin{abstract}
In this study, two pilot-scale pig manure composting piles were constructed for a systematic investigation of arsenic (As) methylation during manure composting. Microbial community composition, as well as the abundance and diversity of arsM genes were monitored using real-time PCR (qPCR) and amplicon sequencing of both 16S rRNA and arsM genes. Results show an overall accumulation of methylated As occurring during 60 day-composting time. The arsM gene copies increased gradually over time and were correlated positively to the concentrations of methylated As. 16S rRNA gene sequencing and arsM clone library analysis confirmed that the high abundance and diversity of arsM genes shared the same known As-methylating microbes, including Streptomyces sp., Amycolatopsis mediterranei and Sphaerobacter thermophiles, which were likely involved in the methylation process. These results demonstrated that As methylation during manure composting is significant. For the first time, the linkage between As biomethylation and the abundance and diversity of the arsM functional gene in composting manure was established.
\end{abstract}

\section{INTRODUCTION}

Arsenic (As)-based feed additives are commonly used in the poultry and livestock industry. Not readily absorbed in animal tissues, almost all the fed As is excreted without attenuation in manure at concentrations up to $300 \mathrm{mg} \mathrm{kg}^{-1}$ (Kiranmayi et al., 2015). Methylation of As is normally regarded as one of the main detoxification pathways for As in environment, which is catalyzed by S-adenosylmethionine methyltransferase encoded by arsM genes (Qin et al., 2006). Although the mechanism of microbial As methylation is known and arsM genes have been detected in various environments, there remains a limited understanding of how the abundance and diversity of arsM genes correlate with the methylation process during manure composting.

\section{METHODS/EXPERIMENTAL}

\subsection{Composting experiments and sampling}

Two independent pilot-scale $(2.5 \mathrm{~m} \times 1.8 \mathrm{~m} \times 0.75 \mathrm{~m}$ in length, width and height) pig manure compost piles were set up in Hangzhou, China, containing on average $1750 \pm 60 \mu \mathrm{g} \mathrm{kg}^{-1} \mathrm{As}(\mathrm{dw}, \mathrm{n}=3)$. The first manure compost pile (MC1) was composed of $1,200 \mathrm{~kg}$ pig manure and $600 \mathrm{~kg}$ sawdust for optimal $\mathrm{C} / \mathrm{N}$ ratio and water content. The second manure compost pile (MC2) contained $1,200 \mathrm{~kg}$ pig manure and $600 \mathrm{~kg}$ sawdust mixed with burned rice straw. The moisture contents of the composting sites were maintained at approximately $65 \%$ by sprinkling water once every two days.
The compost piles were turned over and mixed once every two days in the first month, and once every four days in the second month for aeration. The whole composting process lasted for $60 \mathrm{~d}$, and $2 \mathrm{~kg}$ samples were collected on day $1,5,15,25,35,45$ and 60 .

\subsection{Analysis method}

Concentrations of As species were measured by High-Performance Liquid Chromatography Coupled with Inductively Coupled Plasma Mass Spectrometry (HPLC-ICP-MS, NEXION300XX, PerkinElmer, Inc., USA). Total DNA was extracted and copy numbers of arsM gene in the compost samples were estimated by qPCR. 16S rRNA gene was amplified, then sent for sequencing using Illumina Miseq sequencing platform (Miseq, Illumina Inc., USA). Four samples (15-MC1, 15-MC2, 60-MC1 and 60-MC2) were selected for the construction of ars $M$ gene clone libraries. The detail were described elsewhere (Zhai et al., 2017).

\section{RESULTS AND DISCUSSION}

\subsection{The change of As species during composting}

The total concentrations of methylated As species increased more rapidly during the mesophilic and thermophilic phases, while only small increases during the maturing phase. The concentrations of methylated As species represented 37\% (MC1) and 35\% (MC2) of total As concentration by day 60, clearly indicating As methylation during manure composting. Methylated As species analysis also showed that MMA 


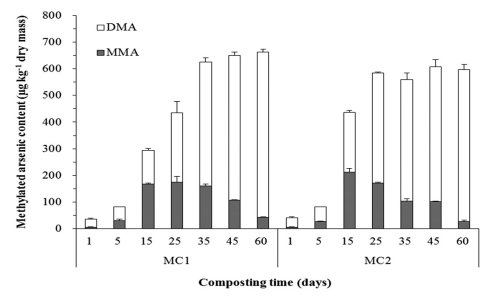

Figure 1. Changes in concentrations of methylated As (MMA and DMA) in the two compost piles.

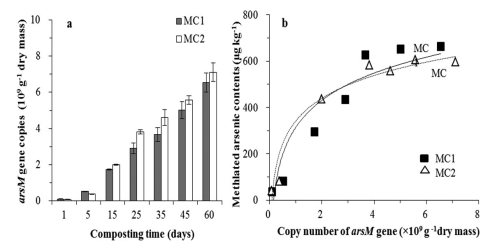

Figure 2. Plot of arsM gene copies (a) and plot of methylated As concentration versus arsM copies in two compost piles (b).

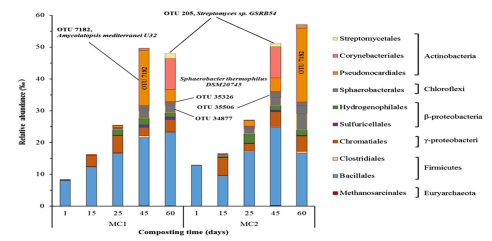

Figure 3. Changes and taxa of selected 16S OTUs related to As methylation.

content in both compost piles peaked during the thermophilic phase (day 5-42) and dropped rapidly during the maturing phase (day 43-60). In contrast, DMA concentrations increased steadily in both compost piles over the composting period (Fig. 1), indicating the transformation of MMA to DMA. And the conversion of DMA to TMA is the rate limiting step in As methylation. Therefore, DMA commonly accumulates in environment samples.

\subsection{Copy numbers of bacterial arsM genes}

The abundance of arsM genes in MC1 and MC2 as a function of composting time increased gradually from $\sim 0.1 \times 10^{9}$ to $\sim 6.8 \times 10^{9}$ copies g-1 dry mass in both piles (Fig. 2a). Further, the sum of MMA and DMA concentrations at different time points was found to correlate strongly with the ars $M$ gene copy numbers (Fig. 2b). Considering the arsM gene is the key functional gene responsible for microbial As methylation, the positive relationship between the concentrations of methylated As and the copy numbers of arsM genes confirmed the As methylation ability in the manure compost piles.

\subsection{Abundance and biodiversity of ars $M$ genes}

We aligned the 16S rRNA sequences from the compost piles against $16 \mathrm{~S}$ rRNA sequences from microbes

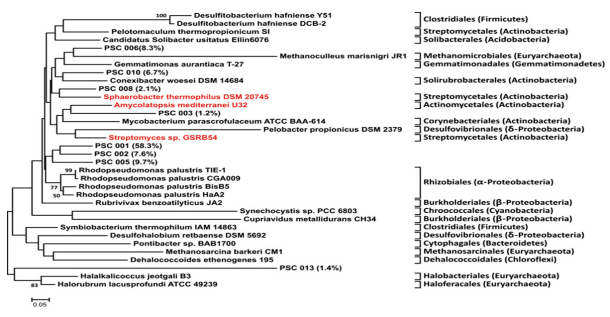

Figure 4. Neighbor-joining analyses of arsM sequences retrieved from composting samples.

containing an arsM gene. Eighty-three OTUs were identified as matching (similarity $\geq 95 \%$ ) and their relative abundances clearly increased with composting time (Fig. 3). A Neighbor-joining tree of the 8 most abundant ars $M$ PSCs ( $>1 \%$ relative abundance) was constructed with selected references. Phylogenetic analysis of arsM clone showed the high diversity of arsM gene in the composting samples (Fig. 4). The present study showed putative arsM affiliated with a wide range of phylogenetic taxa that were present in all the composting samples.

\section{CONCLUSIONS}

In conclusion, two pilot-scale pig manure compost piles were established and an accumulation of methylated As was revealed over the composting process. By qPCR, 16S rRNA sequencing and clone libraries, an increasing in abundance and diversity of arsM genes in composting pig manure were confirmed.

\section{ACKNOWLEDGEMENTS}

This work was financially supported by the Provincial Public Technology and Applied Research Projects by Science and Technology Department of Zhejiang Province (2014C33020), the National Key Technology Research and Development Program of the Ministry of Science and Technology of China (2014BAD14B04), Zhejiang Provincial Natural Science Foundation of China (LR13D010001) and Fundamental Research Funds for the Central Universities.

\section{REFERENCES}

Kiranmayi, P. M., Asok, A. \& Lee, B. 2015. Organoarsenicals in poultry litter: Detection, fate, and toxicity. Environ. Int. 75: 68-80.

Qin, J., Rosen, B. P., Zhang, Y., Wang, G.J., Franke, S., \& Rensing, C. 2006. Arsenic detoxification and evolution of trimethylarsine gas by a microbial arsenite Sadenosylmethionine methyltransferase. Proc. Natl. Acad. Sci. U.S.A. 103(7): 2075-2080.

Zhai, W.W., Wong, M.T., Luo, F., Hashmi, M.Z., Liu, X.M., Edwards, E.A., Tang, X.J. \& Xu, J.M. 2017. Arsenic methylation and its relationship to abundance and diversity of arsM genes in composting manure. Sci. Rep. 7: 42198. 


\title{
Hydrogeological and geochemical comparison of high and low arsenic groundwaters in the Hetao Basin, Inner Mongolia
}

\author{
H.Y. Wang \\ Institute of Mineralogy and Geochemistry, Karlsruhe Institute of Technology, Karlsruhe, Germany
}

\begin{abstract}
For deeply understanding the arsenic mobilization mechanisms of groundwater in Hetao Basin of Inner Mongolia, sediments and groundwater samples from two multi-level wells (up to $80 \mathrm{~m}$ ) were analyzed. The results showed that the sediment As content from well with high As concentration (K1) is higher than the well with low As concentration groundwater (K2), with the average As concentrations 14.7 and $12.8 \mathrm{mg} \mathrm{kg}^{-1}$ respectively. Interestingly, we found a gray-black peat layer (around $28 \mathrm{~m}$ ) from the $\mathrm{K} 2$, with arsenic concentration $322 \mathrm{mg} \mathrm{kg}^{-1}$, while the TOC content and TS contents are up to $9.6 \%$ and $1.8 \%$, respectively. The pyrite also was found in this layer. We conclude that the organic matter triggers the formation of arsenic-sequestering sulphides under strongly reducing conditions, therefore immobilization of As into the sediments. By bonding arsenic in this way, the peat layer occurred in the aquifer plays an active role for arsenic immobilization into the sediments.
\end{abstract}

\section{INTRODUCTION}

The Hetao Basin in the Inner Mongolia is one of most serious As-polluted area in China (Guo et al., 2014; Liu et al., 2017). Groundwater with high As concentration (up to $879 \mu \mathrm{g} \mathrm{L}^{-1}$ ) has been widely found in the Hetao Basin, with 76000 people exposed in 35 villages in 2002 (Liu et al., 2017).

For better understanding the mechanisms of As mobilization, we drilled two boleholes up to $80 \mathrm{~m}$ in Hangjinhoujin, one countryside highly affected by As pollution. The sediments from different layers were analyzed based on mineralogy and chemistry characters. And the relevance was established between the sediments property and groundwater As concentration.

\section{METHODS}

\subsection{Study area}

The Hetao Basin is located in between Yellow river to the south and Langshan to the north. Lacustrine deposition and frequent channel changes caused the patchy sediments distribution and allowed organic matter to accumulate in the sediments during Pleistocene and Holocene period. Hanginhouqi country located in the west of Hetao basin is one of the serious arsenicaffected areas where the groundwater was mainly used for irrigation system.

\subsection{Sediments characterization}

Two boreholes up to $80 \mathrm{~m}$ were drilled at the Hangjinhouqi in October of 2015. The XRF analysis was used to determine the mineral phases and major chemical components. The total carbon components (TC) and
TS as well as organic matter (TOC) were qualified using carbon-water analyzer. The EC (electric conductivity) value of soluble contents and $\mathrm{pH}$ values of sediments were also measured by method of solid-toliquid ratio of 1:5.

\subsection{Groundwater sampling and analysis}

After sediment sampling, the multi-level wells were installed. The water was pumped from the different depth. Groundwater parameters including temperature (T), $\mathrm{pH}$, redox potential (ORP), electrical conductivity (EC) were measured in the field. The major cations including As and anions were measured by ICP-MS and ICP-OES respectively.

\section{RESULTS AND DISCUSSION}

\subsection{Sediment geochemistry}

The average sediment grain sizes from K2 borehole are larger than $\mathrm{K} 1$, while the medium-coarse sands distribute in 35-40 $\mathrm{m}$ and 51-60 $\mathrm{m}$ from K2 borehole, they are rarely found in $\mathrm{K} 1$. Compared with $\mathrm{K} 1$, clay layers are also widely distributed in $\mathrm{K} 2$ with yellowbrown layers found in the depth around $16 \mathrm{~m}, 26 \mathrm{~m}$, $41 \mathrm{~m}, 51 \mathrm{~m}, 59 \mathrm{~m}, 65 \mathrm{~m}$ respectively, while only two clay layers appeared in $\mathrm{K} 1$ with the depth around $3 \mathrm{~m}$ above the aquifer, and $40 \mathrm{~m}$, respectively.

The sediment As contents ranged from 5.8 to $28.9 \mathrm{mg} \mathrm{kg}^{-1}$ (Table 1) with higher As contents of clay samples. Therefore, the clay layers intersected in the aquifers can be a major As sink or source. The As contents are well correlated with $\mathrm{Fe}$ contents in the sediments, rather than TOC and TS. So the As occurred in the aquifer are mostly from the 
Table 1. Chemical compositions of sediment samples collected from two boreholes in the western Hetao basin a: K1, b: $\mathrm{K} 2$ (except one sample with As content up to $322 \mathrm{mg} \mathrm{kg}^{-1}$ ). $\mathrm{a}:$

\begin{tabular}{lllllll}
\hline $\begin{array}{l}\text { Value } \\
\text { range }\end{array}$ & $\begin{array}{l}\mathrm{Fe}_{2} \mathrm{O}_{3} \\
(\mathrm{wt} \%)\end{array}$ & $\begin{array}{l}\mathrm{MnO} \\
(\mathrm{wt} \%)\end{array}$ & $\begin{array}{l}\mathrm{As} \\
\left(\mathrm{mg} \mathrm{kg}^{-1}\right)\end{array}$ & $\begin{array}{l}\mathrm{TOC} \\
(\%)\end{array}$ & $\begin{array}{l}\mathrm{TIC} \\
(\%)\end{array}$ & $\begin{array}{l}\mathrm{TS} \\
\left(\mathrm{mg} \mathrm{kg}^{-1}\right)\end{array}$ \\
\hline Maximum & 7.15 & 0.120 & 40.9 & 0.60 & 2.15 & 5125 \\
$75 \% \mathrm{Q}$ & 5.76 & 0.092 & 21.0 & 0.37 & 1.64 & 512 \\
Median & 3.39 & 0.047 & 12.1 & 0.13 & 0.97 & 287 \\
$25 \% \mathrm{Q}$ & 2.14 & 0.034 & 7.71 & 0.06 & 0.63 & 231 \\
Minimum & 1.61 & 0.023 & 5.82 & 0.04 & 0.32 & 140 \\
Average & 3.80 & 0.060 & 14.7 & 0.20 & 1.14 & 573 \\
$\mathrm{R}_{\mathrm{Fe}}^{2}$ & - & 0.93 & 0.75 & 0.61 & 0.80 & 0.0052 \\
$\mathrm{R}_{\mathrm{As}}^{2}$ & - & 0.61 & - & 0.35 & 0.40 & 0.0375 \\
\hline
\end{tabular}

b:

\begin{tabular}{llllllll}
\hline Maximum & 6.85 & 0.109 & 28.9 & 0.90 & 1.92 & 5438 \\
$75 \% \mathrm{Q}$ & 5.17 & 0.083 & 16.1 & & 0.47 & 1.74 & 685 \\
Median & 3.59 & 0.056 & 11.9 & 0.20 & 1.16 & 322 \\
$25 \% \mathrm{Q}$ & 2.16 & 0.029 & 6.59 & 0.06 & 0.53 & 226 \\
Minimum & 1.68 & 0.025 & 5.03 & 0.05 & 0.31 & 179 \\
Average & 3.69 & 0.058 & 12.8 & 0.2 & 1.10 & 724 \\
$\mathrm{R}_{\mathrm{Fe}}^{2}$ & - & 0.97 & 0.74 & 0.48 & 0.7 & 0.16 \\
$\mathrm{R}_{\mathrm{As}}^{2}$ & - & 0.66 & - & 0.50 & 0.6 & 0.35 \\
\hline
\end{tabular}

dissolution of $\mathrm{Fe} / \mathrm{Mn}$ (hydro) oxides or the $\mathrm{Fe}(\mathrm{Mn})$ oxides-TOC-As complexes.

The average As content $\left(14.7 \mathrm{mg} \mathrm{kg}^{-1}\right)$ in the $\mathrm{K} 1$ borehole is higher than in the $\mathrm{K} 2\left(12.7 \mathrm{mg} \mathrm{kg}^{-1}\right)$ (Table 1). It may be an important reason for higher groundwater As concentration from K1 well.

Interestingly, we found a gray-black peat layer in the $\mathrm{K} 2$ borehole, The deep sand layer contains trees and plants debris extending from 25.8 to $28.4 \mathrm{~m}$ with the As and TOC contents up to $322 \mathrm{mg} \mathrm{kg}^{-1}$ and $9.6 \%$ respectively. XRD spectra was used to investigate the mineral compositions, revealing that the pyrite minerals appeared in this layer. Under reducing conditions, the S-enriched peat can implicate as a fuel for reductive dissolution of arsenic-bearing iron (hydro) oxides, then accelerate the formation of arsenic-contained pyrite as a result of sufides reacting with the Fe (II).

\subsection{Soluble salts in the sediments}

Generally, the clay and silt samples exhibited higher salinity than the sand. However, the sand layers in the depth of around $80 \mathrm{~m}$ in $\mathrm{K} 1,28 \mathrm{~m}$ and $69 \mathrm{~m}$ in $\mathrm{K} 2$ released high contents of salts due to the high TOC contents (Fig. 1a). The sample EC values near the land surface from $\mathrm{K} 1$ are much higher than from $\mathrm{K} 2$, indicating that the groundwater from K1 well experienced long time evaporation and caused the salts accumulation in the surface sediments. Contrasting with K1, the sediments from K2 experienced long-term flushing history with low $\mathrm{EC}$ values appearing at different aquifer sediments.

Compared with higher sediment As concentration from $\mathrm{K} 1$ borehole, the sediments from $\mathrm{K} 2$ have higher $\mathrm{pH}$ value (Fig. 1a). It may be due to that at alkaline

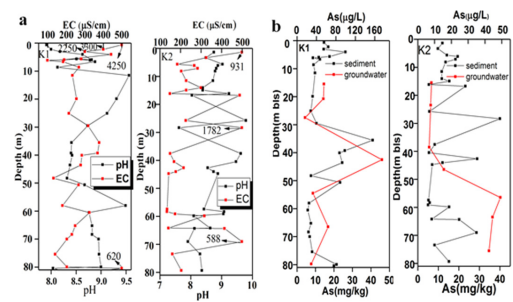

Figure 1. (a) EC value and $\mathrm{pH}$ of sediments varies with depth, (b) As concentrations of groundwater and sediments varies with dept.

conditions, dissolved Fe concentrations did not significantly increase upon reduction. Furthermore, the presence of soluble organics under alkaline conditions and the formation of iron oxyhydroxides-organic matter complexes could have retarded Fe reduction and the release of As into solution.

\subsection{Hydrogeochemistry}

The groundwater from $\mathrm{K} 2$ well showed higher $\mathrm{pH}$, consisting with higher $\mathrm{pH}$ in the sediments. The total dissolved solids (TDS) range from 449 to $3136 \mathrm{mg} \mathrm{L}^{-1}$, and decline with the depth. The groundwater from $\mathrm{K} 1$ well experienced long-time water-rock interaction or evaporation process with higher EC value. The groundwater samples from $\mathrm{K} 1$ well are mostly $\mathrm{Na}-\mathrm{Cl}-$ $\mathrm{SO}_{4}$ or $\mathrm{Na}_{-} \mathrm{SO}_{4}-\mathrm{Cl}$ type, while samples from $\mathrm{K} 2$ well are mostly $\mathrm{Na}(\mathrm{Ca})-\mathrm{HCO}_{3}-\mathrm{SO}_{4}$ type.

The ORP values of both wells are similar under anoxic conditions except the depth of $15-16 \mathrm{~m}$ in K2 well. The groundwater As concentrations from different depths of K2 well are lower than $50 \mu \mathrm{g} \mathrm{L}^{-1}$, and increased with depth (Fig. 1b). Even though the sediment As content in the depth of $28 \mathrm{~m}$ from K2 borehole is up to $322 \mathrm{mg} \mathrm{L}^{-1}$, the As concentration in the groundwater according to this depth is lower than $10 \mu \mathrm{g} \mathrm{L}^{-1}$. Therefore, we conclude that the peat layers accelerate the As immobilization into the sediments.

The groundwater As concentrations in K1 vary with the sediment As contents. The As concentration in the depth of $42.5 \mathrm{~m}$ is $174 \mu \mathrm{g} \mathrm{L}^{-1}$ while the As content in the upper clay sediment is up to $25 \mathrm{mg} \mathrm{kg}^{-1}$ (Fig. 1b). Under reducing conditions, the DOC released from clay layers above this aquifer may afford the electrons for release of $\mathrm{Fe}$ (hydro) oxides.

\section{REFERENCES}

Guo, H.M., Wen, D.G., Liu, Z.Y., Jia, Y.F. \& Guo, Q. 2014. A review of high arsenic groundwater in mainland and Taiwan, China: distribution, characteristics and geochemical processes. Appl. Geochem. 41: 196-217.

Liu, N.J., Deng, Y.M. \& Wang, Y. 2017. Arsenic, iron and organic matter in quaternary aquifer sediments from western Hetao Basin, Inner Mongolia. J. Earth Sci. 28: 473-483. 


\title{
Effects of sediment properties and organic matter on biomobilization of arsenic from aquifer sediments in microcosms
}

\author{
Z. Xie, M. Chen, J. Wang, X. Wei, F. Li, J. Wang \& B. Gao \\ School of Environmental Studies, China University of Geosciences, Wuhan, Hubei, P.R. China
}

\begin{abstract}
In this study, the reducing capacity of the strain Bacillus cereus in the two sediments from Datong Basin and Jianghan Plain was investigated by examining the concentrations of As and Fe and the changes of $\mathrm{pH}$ and Eh. Results showed that glucose contributed to the mobilization of As and Fe, and As in the sediment from Jianghan Plain was released more easily. It was found that Bacillus cereus changed the $\mathrm{pH}$ and Eh in the surroundings, and promoted the reductive dissolution of $\mathrm{As}(\mathrm{V})$ and $\mathrm{Fe}(\mathrm{III})$ in the sediments to enhance As in groundwater.
\end{abstract}

\section{INTRODUCTION}

Arsenic (As) is an important element for human carcinogen. More and more people are suffering arsenism for long-term drinking arsenic-contaminated groundwater. Mobilization and enrichment of arsenic in groundwater were affected by several environmental factors.

The objectives of this study were to evaluate the influences of sediment properties and organic matter on bacterial migration of arsenic.

\section{MATERIALS AND METHODS}

\subsection{Bacterial culture}

The strain Bacillus cereus (B. cereus) was isolated from the aquifer sediment. The bacterial strain was cultured in modified minimal salt medium (MSM) in an incubator in dark at $25^{\circ} \mathrm{C}$ for $4 \mathrm{~d}$. Salts supplied per liter of MSM were: $0.14 \mathrm{~g} \mathrm{KH}_{2} \mathrm{PO}_{4}, 0.50 \mathrm{~g} \mathrm{KCl}$, $1.00 \mathrm{~g} \mathrm{NaCl}, 0.13 \mathrm{~g} \mathrm{CaCl}_{2}$ and $0.62 \mathrm{~g} \mathrm{MgCl}_{2} \cdot 6 \mathrm{H}_{2} \mathrm{O}$. The bacterial cells were harvested by centrifugation at $4000 \mathrm{rpm}$ for $20 \mathrm{~min}$ at $4^{\circ} \mathrm{C}$. The cell pellets were resuspended and cultured in the fresh MSM for the next experiments.

\subsection{Sediment characterization}

Total organic $\mathrm{C}$ (TOC), As, Fe, $\mathrm{pH}$ and mineral size distribution of sediment particles were determined as the methods described in Simmler et al. (2016).

\subsection{Microcosm experiments}

Two sediment samples were collected from high arsenic aquifers at Datong Basin and in Jianghan Plain. The two samples were named as SDB and SJP, respectively. The microcosms were prepared in $500 \mathrm{~mL}$ Erlenmeyer flasks with rubber stoppers. In $\mathrm{N}_{2}$ filled glove box, $10 \mathrm{~mL}$ of the bacterium in exponential growth phase were incubated in the Erlenmeyer flask with $0.4 \mathrm{~g}$ glucose or $0.5 \mathrm{~g}$ fulvic acid, $20 \mathrm{~g}$ sieved sediment and $200 \mathrm{~mL}$ deionized water. Sediment, Erlenmeyer flask and deionized water were autoclaved prior to use. All the Erlenmeyer flasks were incubated in nitrogen atmosphere, in dark at $25^{\circ} \mathrm{C}$. The control groups without organic matter or bacterium were run under the same conditions.

\subsection{Chemical analyses of the aqueous phase}

Before collecting the samples, $\mathrm{pH}$ and Eh were measured directly in the water-sediment system in the $\mathrm{N}_{2}$-filled glove box. Dissolved As(III), As(V), Fe(II) and $\mathrm{Fe}(\mathrm{III})$ in the solutions from the microcosms were determined. At regular time intervals, $5 \mathrm{~mL}$ of sample were removed from each reaction vessel and centrifuged. As(III) and As(V) were separated from the supernatant by a strong anion exchange column and measured by hydride generation-atomic fluorescence spectrometry. $\mathrm{Fe}(\mathrm{II})$ and $\mathrm{Fe}(\mathrm{III})$ were determined according to the method of Han et al. (2011).

\section{RESULTS AND DISCUSSION}

\subsection{Sediment characterization}

The content of sand in the two samples was high as shown in Table 1. Nevertheless, sand in SJH had higher percentage. The $\mathrm{pH}$ values of SDB and SJP were in slightly alkaline. The contents of TOC in sediments had obvious difference. In addition, the contents of As and Fe in SDB exceeded in SJH. The results indicated that the two sediment samples had different characterization.

\subsection{Speciation and mobilization of As and $\mathrm{Fe}$}

The concentrations of dissolved As(V), As(III), Fe(III) and $\mathrm{Fe}(\mathrm{II})$ in aqueous phase in the microcosm were presented in Figure 1. From the figure, we can see that all the concentrations increased over time under the condition of bacterial activities. The concentrations of 


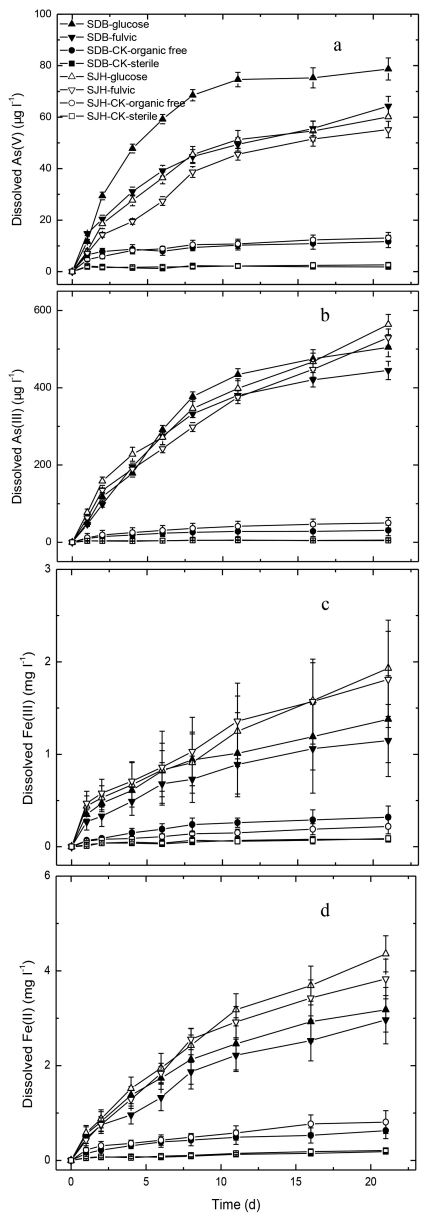

Figure 1. Dissolved As(V), As(III), Fe(III) and Fe(II) in aqueous phase in the microcosm. a) $\mathrm{As}(\mathrm{V})$; b) $\mathrm{As}(\mathrm{III})$; c) $\mathrm{Fe}(\mathrm{III})$; d) $\mathrm{Fe}(\mathrm{II})$.

Table 1. Physicochemical characteristics of sediment samples.

\begin{tabular}{lcc}
\hline & SDB & SJH \\
\hline $\mathrm{pH}$ & 7.9 & 7.6 \\
$\mathrm{TOC}(\%)$ & 0.19 & 0.56 \\
${\mathrm{As}\left(\mathrm{mg} \mathrm{kg}^{-1}\right)}_{\mathrm{Fe}_{2} \mathrm{O}_{3}(\%)}^{13.3}$ & 9.8 \\
$\mathrm{Sand}(50-2000 \mu \mathrm{m})(\%)$ & 2.89 & 2.23 \\
$\mathrm{Silt}(2-50 \mu \mathrm{m})(\%)$ & 61.7 & 76.8 \\
Clay $(<2 \mu \mathrm{m})(\%)$ & 27.7 & 18.3 \\
\end{tabular}

$\mathrm{As}(\mathrm{III})$ and $\mathrm{Fe}(\mathrm{II})$ exceed those of $\mathrm{As}(\mathrm{V})$ and $\mathrm{Fe}(\mathrm{III})$ at the same sampling time. Additionally, the concentrations except $\mathrm{As}(\mathrm{V})$ in $\mathrm{SJH}$ microcosm were higher than in SDB microcosm. Glucose contributes to the mobilization of As and Fe. The results suggested that $B$. cereus promoted the reductive dissolution of As( $\mathrm{V})$ and $\mathrm{Fe}(\mathrm{III})$ in the sediments.

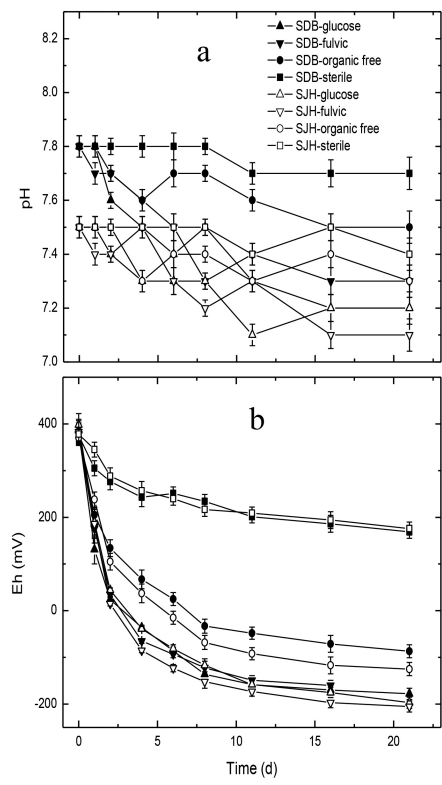

Figure 2. Change of $\mathrm{pH}$ and Eh. a) $\mathrm{pH}$; b) Eh.

\subsection{Change of Eh and $\mathrm{pH}$}

It was shown that $B$. cereus affected the $\mathrm{pH}$ and $\mathrm{Eh}$ of the microcosms microcosms (Fig. 2). The change of $\mathrm{pH}$ and Eh contributed to mobilization of As and Fe.

\section{CONCLUSIONS}

From this study, it was found that the strain Bacillus cereus changed the environment factors and promoted the reductive dissolution of $\mathrm{As}(\mathrm{V})$ and $\mathrm{Fe}(\mathrm{III})$ in the sediments. Then, As and Fe were released into groundwater from sediments.

\section{ACKNOWLEDGEMENTS}

This research work was financially supported by National Natural Science Foundation of China (Grant Nos. 41572230 and 41172219), and by the Grant for Innovative Research Groups of the National Natural Science Foundation of China (41521001).

\section{REFERENCES}

Han, X., Li, Y.L. \& Gu, J.D. 2011. Oxidation of As(III) by $\mathrm{MnO}_{2}$ in the absence and presence of $\mathrm{Fe}(\mathrm{II})$ under acidic conditions. Geochim. Cosmochim. Acta. 75: 368-379.

Simmler, M., Suess, E., Christl, I., Kotsev, T. \& Kretzschmar, R. 2016. Soil-to-plant transfer of arsenic and phosphorus along a contamination gradient in the mining-impacted Ogosta River floodplain. Sci. Total Environ. 572: 742-754. 


\title{
Organic acid effect on arsenate bioaccessibility in gastric and alveolar simulated biofluid systems
}

\author{
S.Q. Kong ${ }^{1,2}$, R.A. Root $^{3} \&$ J. Chorover ${ }^{3}$ \\ ${ }^{1}$ School of Environmental Studies and State Key Laboratory of Biogeology and Environmental Geology, \\ China University of Geosciences, Wuhan, P.R. China \\ ${ }^{2}$ Laboratory of Basin Hydrology and Wetland Eco-restoration, School of Environmental Studies, China University of \\ Geosciences, Wuhan, P.R. China \\ ${ }^{3}$ Department of Soil, Water and Environmental Science, University of Arizona, Tucson, AZ, USA
}

\begin{abstract}
The risk posed from incidental ingestion of arsenate-contaminated tailings may depend on sorption of arsenate to oxide surfaces in minerals. Popularly organic matter existing in tailings influenced bioaccessibility of arsenate. Arsenate adsorbed minerals were placed in simulated gastric and alveolar (in vitro) to ascertain the bioaccessibility of arsenate and changes in arsenate surface speciation caused by the biofluid systems. The effects of organic matter on arsenate bioaccessibility were investigated by adding oxalic and vanllic acid to biofluid systems. These results suggest that the bioaccessibility of arsenate is increased by organic matter and increasing reaction time.
\end{abstract}

\section{INTRODUCTION}

Potential exposure to arsenic (As) basically through ingesting or breath from tailings may pose a risk to human health. In physiological systems of the human body, some of the uptake arsenic may become soluble (Meunier et al., 2010). That is the presence or the artificial addition of natural organic matter may influence the mobility of arsenic previously adsorbed onto soil or tailings particle surfaces (Redman et al., 2002; Wang \& Mulligan, 2009). The in vitro bioassays in this work were carried out in simulated biofluid reacted with several minerals and organic matter. Two synthetic systems included gastric and alveolar simulation biofluid. Ferrihydrite, scorodite and goethite are represented as typical iron oxide minerals in nature. Two representative organic matter, oxalic acid and vanillic acid, represented alkanes and aromatic hydrocarbons. Arsenate was operated in the assays as it is the common arsenic speciation in tailings.

\section{METHODS AND EXPERIMENTAL}

\subsection{In vitro bioassay}

A physiologically based extraction test (PBET) was used to estimate the bioaccessibility of arsenic from $\mathrm{As}(\mathrm{V})$-containing minerals, as well as from samples mixed with and without natural organic matter.

\subsection{Estimation of arsenic bioaccessibility}

Arsenate bioaccessibility was calculated by dividing the arsenate concentration $(\mu \mathrm{g} / \mathrm{g})$ measured in the in vitro gastric solution or the in vitro alveolar solution by the total soil arsenate concentration $\left(\mu \mathrm{g} \mathrm{g}^{-1}\right)$, as described by the following equation (Rodriguez \& Basta, 1999; Pouschat \& Zagury, 2006):

As bioaccessibility $(\%)=($ in vitro As $) /($ Total As $) \times 100$

\section{RESULTS AND DISCUSSION}

\subsection{Arsenate bioaccessibility}

The in vitro bioassay showed that the bioaccessible As in the $\mathrm{As}(\mathrm{V})$-ferrihydrite, scorodite and $\mathrm{As}(\mathrm{V})$ goethite is intermediate (bioaccessibility: 6.96 to $15.77 \%)$. As(V)-ferrihydrite showed the lowest total As release content (G: 26.35 to $56.99 \mathrm{mg} \mathrm{L}^{-1}$ and A: 9.23 to $21.89 \%$ ), but the highest As bioaccessibility (G: 17.57 to $38.01 \%$ and A: 6.16 to $14.60 \%$ ). In the study, organic carbon concentration $(\sim 0.1 \mathrm{wt} \%)$ and minerals levels $(\sim 1 \mathrm{wt} \%)$ suggest that mineralogical characteristics and organic matter content play important roles in the As bioaccessibility of the minerals. The effects of two representative organic matter, oxalic acid and vanillic acid represented alkanes and aromatic hydrocarbons, are similar to different minerals in gastric and alveolar biofluids. It shows that organic acid increases arsenate bioaccessibility and $\mathrm{As}(\mathrm{V})$ content in biofluid. With increasing $\mathrm{As}$ and $\mathrm{Fe}$ concentrations, the relative gastric and alveolar bioaccessibility decreased similarly, despite the different chemical conditions of the two extraction fluids (e.g., pH 1.8 vs 7.4, anaerobic and aerobic).

The sorption behavior of arsenate in soil is highly dependent on organic carbon, while the desorption 


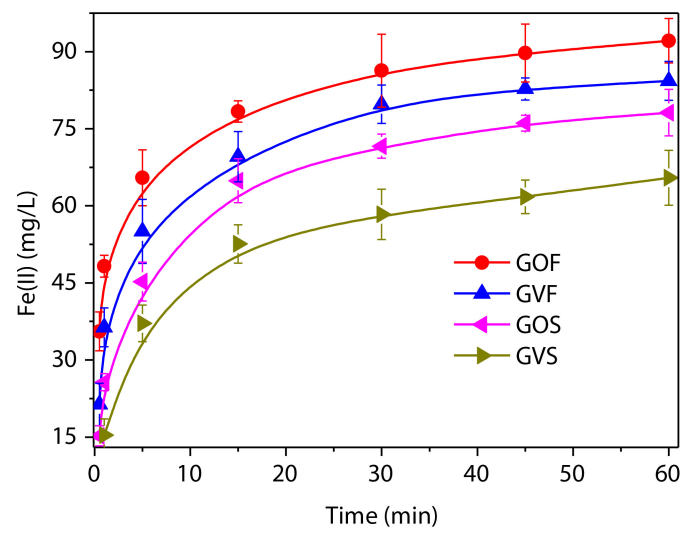

Figure 1. Ferrous concentration in simulated gastric biofluid with time.

is critically influenced by the high concentrations of amorphous and/or crystalline iron oxides. These factors control bioaccessibility after release of As from the crystalline mineral structure. In simulated bio-fluid systems, iron oxides dissolved at specific $\mathrm{pH}$, leading to arsenic release from surface of minerals and formation of ferric hydroxide colloid. A part of released arsenate was re-adsorbed on solid surface through complex with hydroxyl of minerals (Fendorf et al., 1997). Existing of organic matter influenced both the dissolution of minerals and arsenic re-adsorption.

\subsection{Species of Fe and As}

Speciation of As and Fe released were determined for three minerals. There was no detectable As(III) neither in the anaerobic gastric nor in the alveolar fluid. This means that $\operatorname{As}(\mathrm{V})$ was not reduced to more toxic As(III) even in anaerobic gastric phase. It is a good phenomenon considering human health. The assay indicated that the $\mathrm{Fe}$ that was solubilized during the alveolar phase was totally $\mathrm{Fe}(\mathrm{III})$. At the $\mathrm{pH}$ of 7.4 of the alveolar phase, $\mathrm{Fe}$ (II) would be soluble, but Fe(III) is insoluble. Speciation of $\mathrm{Fe}$ in gastric phase shows that detective $\mathrm{Fe}$ (II) occurred after organic matter addition (Fig. 1). $\mathrm{Fe}$ (II) was the $\mathrm{Fe}$ (III) reduction product by the organic substances (Theis \& Singer, 1974).

\subsection{Stoichiometry of release Fe and As}

Stoichiometry of release Fe and As uncovered minerals dissolution and arsenic desorption from solid surface. From the results of Fe:As, it shows that the ratios of $\mathrm{As}(\mathrm{V})$-Ferrihydrite and $\mathrm{As}(\mathrm{V})$-goethite in gastric phase were beyond adsorption ratio values, illustrating that As bioaccessibility derived from a dominant process of dissolution minerals. However, in alveolar phase, the ratios implied arsenic release attributed to As desorption from minerals. As for scorodite, a ratio of iron to arsenic nearly 1:1 crystallization mineral, its disintegration led to stoichiometry of release Fe and As very close to $1: 1$, regardless in gastric and alveolar phases.
Comparison of the same solids in two biofluid phases, shows a stoichiometric increment $\mathrm{Fe}$ and As with adding organic matter in gastric phase, and ox-alic acid increased more than vanllic acid. The results means that organic matter inhibited the process of mineral dissolution, while facilitated arsenic desorption. Ionization of organic matter produced hydrogen ions, which inhibited producing hydrogen ions of original gastric phase at the same $\mathrm{pH}$, and then hydroxide ions increased to maintain ion product, leading to increasing ferric hydroxide colloid, and finally improving mineral dissolution. A part of additional organic matter was adsorbed onto the surface of minerals. It was competitive with arsenic on surface activity sites, attributing to arsenic desorption, since organic matter occupied some adsorption sites and inhibited iron release from minerals.

\section{CONCLUSIONS}

Organic acid increased arsenic bioaccessibility in gastric and alveolar simulated biofluids. Iron species changed to ferrous iron to a certain extent. Arsenate was not transform to arsenite. The ratios of release $\mathrm{Fe}$ and As are 1:1 for the three minerals containing arsenate in the biofluids.

\section{ACKNOWLEDGEMENTS}

This research was supported by the National Natural Science Foundation of China (no. 41402214).

\section{REFERENCES}

Fendorf, S., Eick, M.J., Grossl, P. \& Sparks, D.L. 1997. Arsenate and chromate retention mechanisms on goethite 1 . Surface structure. Environ. Sci. Technol. 31(2): 315-320.

Meunier, L., Walker, S.R., Wragg, J., Parsons, M.B., Koch, I., Jamieson, H.E. \& Reimer, K.J. 2010. Effects of soil composition and mineralogy on the bioaccessibility of arsenic from tailings and soil in gold mine districts of Nova Scotia. Environ. Sci. Technol. 44(7): 2667-2674.

Pouschat, P. \& Zagury, G.J. 2006. In vitro gastrointestinal bioavailability of arsenic in soils collected near CCA-treated utility poles. Environ. Sci. Technol. 40(13): 4317-4323.

Redman, A.D., Macalady, D.L. \& Ahmann, D. 2002. Natural organic matter affects arsenic speciation and sorption onto hematite. Environ. Sci. Technol. 36(13): 2889-2896.

Rodriguez, R.R. \& Basta, N.T. 1999. An in vitro gastrointestinal method to estimate bioavailable arsenic in contaminated soils and solid media. Environ. Sci. Technol. 33(4): 642-649.

Theis, T.L. \& Singer, P.C. 1974. Complexation of iron(II) by organic matter and its effect on iron(II) oxygenation. Environ. Sci. Technol. 8(6): 569-573.

Wang, S.L. \& Mulligan, C.N. 2009. Effect of natural organic matter on arsenic mobilization from mine tailings. $J$. Hazard. Mater. 168(2-3): 721-726. 


\title{
Abundance, size distribution and dissolved organic matter binding of arsenic in reducing aquifer
}

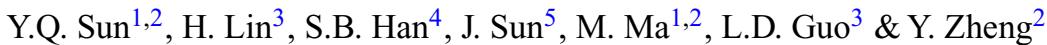 \\ ${ }^{1}$ College of Engineering, Peking University, Beijing, China \\ ${ }^{2}$ School of Environmental Science and Technology, Southern University of Science and Technology, Shenzhen, China \\ ${ }^{3}$ School of Freshwater Sciences, University of Wisconsin-Milwaukee, WI, USA \\ ${ }^{4}$ Center for Hydrogeology and Environmental Geology Survey, China Geological Survey, Baoding, China \\ ${ }^{5}$ School of Earth Sciences, University of Western Australia, Perth, Western Australia, Australia
}

\begin{abstract}
The interactions between As and dissolved organic matter (DOM) have significant impacts on the environmental behavior of As. Among various interactions, the binary complexes of As bound to DOM and ternary complexes of As bound to DOM with iron (Fe) bridging, are critical to mobility, speciation, toxicity and bioavailability of As. Flow field flow fractionation (FIFFF) offline with high-resolution inductively coupled plasma mass spectroscopy (HR-ICPMS) were utilized to elucidate the As, Fe and DOM complexation in high arsenic, reducing groundwater from Yinchuan plain. The majority $(>70 \%)$ of As was truly dissolved with molecular size $<0.5 \mathrm{~nm}$; while $13 \%$ of As and $37 \%$ of Fe were bound to colloidal DOM with molecular size between $16-64 \mathrm{~nm}$. The results imply that As-Fe-DOM complex is distributed as moderately large colloids with molecular size between $16-64 \mathrm{~nm}$. However, artefacts due to changes occurring during sample storage and transportation cannot be ruled out. Thus, field ultrafiltration under $\mathrm{N}_{2}$ atmosphere will be employed in the future to validate FIFFF results.
\end{abstract}

\section{INTRODUCTION}

Exposure to elevated levels of As $\left(>10 \mu \mathrm{gL}^{-1}\right)$ in groundwater has threatened the health of over 100 million people around the world. High As exposure is primarily due to the presence of As sources in aquifers and mobilization of As from sediment to groundwater in microbially mediated reducing environments. Yet the understanding of factors influencing the concentration and mobility of As, especially the role of dissolved organic matter (DOM), is incomplete. DOM is ubiquitous in natural water system and may affect the mobility of As through a number of mechanisms including binding and surface sorption.

McArthur et al., (2001) postulated that microbial degradation of buried deposits peat leads to the reduction of iron (hydro)oxides $(\mathrm{FeOOH})$ and release of $\mathrm{Fe}$ coated As in Bangladesh aquifers. Further, Mladenov et al., (2009) suggested that DOM in reducing groundwater can serve to shuttle electrons and enhance the reductive dissolution of iron (oxy)hydroxide minerals, as evidenced by acceleration of the mobilization of dissolved As in Bangladesh aquifers and Gangetic aquifer of late Holocene. Additionally, DOM and As can form complexation which is relevant to As speciation, mobility and toxicity (Wang \& Mulligan, 2006). The associations involve bridging metals and deprotonated functional groups of organic matter (i.e. carboxyl, hydroxyl and sulphydryl) (Sharma et al., 2010).

Although many laboratory experiments have found evidence for As-(Fe)-DOM complexes in solution, the kinetic and thermodynamic parameters are difficult to compare due to variable experimental settings in these studies. Further, isolation and determination of this complex in groundwater systems remain scarce. Field (ultra) filtration was conducted for groundwater in the Hetao Basin and the result showed that 20\%$40 \%$ As is combined with small-size organic colloids and $75 \%$ iron is in colloids (Guo et al., 2011). Among various interactions, the binary complexes of As bound to DOM and ternary complexes among As, DOM and $\mathrm{Fe}$, is a mechanism that has emerged to be relevant to mobility of As in reducing aquifers. Here, we explore this possibility as well as isolation of DOM bound of As from Yinchuan Plain where reducing groundwater hosts high levels of As.

\section{STUDY AREA AND METHODS}

\subsection{Study area}

Our field site is in Yinchuan alluvial plain where As levels reach $210 \mu \mathrm{gL}^{-1}$ and correlate with Fe concentrations $>1 \mathrm{mg} \mathrm{L}^{-1}$ in groundwater in the shallow aquifer (depth 4-40m). Sediment As and Fe concentrations are also high $\left(>10 \mathrm{mg} \mathrm{kg}^{-1}\right.$ and $\left.1 \% \mathrm{Fe}\right)$ respectively.

\subsection{Method}

Three groundwater samples were selected for analysis of colloidal size distributions by coupling on-line flow field-flow fractionation (FIFFF) with detectors including UV-absorbance and fluorescence. The two UV-absorbance detectors measured the absorbance at 
$254 \mathrm{~nm}$ and $280 \mathrm{~nm}$ respectively, representing the aromatic and protein content. Fluorescence detectors were set for two indexes FLD1 and FLD2 with Ex/Em of $350 \mathrm{~nm} / 450 \mathrm{~nm}$ and $275 \mathrm{~nm} / 340 \mathrm{~nm}$, respectively. Selected elements (As, Fe, S, Mn, and Mg) was determined by HR ICP-MS in off-line fraction samples with $\mathrm{RSD}<5 \%$.

\section{RESULTS AND DISCUSSION}

\subsection{Abundance of selected elements in $0.7 \mu \mathrm{m}$, $0.4 \mu \mathrm{m}$ and $0.2 \mu \mathrm{m}$ filtrates}

For all three groundwater samples, negative ORP values, non-detectable nitrate, and strong sulfide smell during sampling suggest that the groundwater has reached $\mathrm{Fe}$ and sulfate reducing stage. Concentrations of selected elements in three samples for the $0.7 \mu \mathrm{m}$, $0.4 \mu \mathrm{m}$ and $0.2 \mu \mathrm{m}$ filtrates are shown in Table 1 . The unusually high $\mathrm{Fe}$ concentrations in $0.4 \mu \mathrm{m}$ filtrates for YC-1 and MLW-7 may have been due to the filter leakage.

\subsection{Abundance of elements from FlFFF}

The asymmetrical FlFFF system (AF2000, Postnova) was equipped with a $0.3 \mathrm{kDa}$ polyether sulfone ultrafiltration membrane and a $0.35 \mathrm{~mm}$ spacer with $1 \mathrm{~mL}$ of injection volume. A mixed solution with $10 \mathrm{mM}$ $\mathrm{NaCl}(\mathrm{aq})$ and $5 \mathrm{mM} \mathrm{H}_{3} \mathrm{BO}_{3}$ (aq) and $\mathrm{pH}$ of 8 (adjusted with $\mathrm{NaOH}$ ), which was optimized to have the highest recovery and reasonable separation, was used as the carrier solution. Four fractionations with increasing molecular sizes were collected during FlFFF; smallest colloids of $0.5-8 \mathrm{~nm}$, small colloids of $8-16 \mathrm{~nm}$, medium size colloids of 16-64 nm and large colloids of 64-700 nm (Table 1). Concentration in the dissolved fraction $(<0.5 \mathrm{~nm})$ was estimated by subtracting the sum of all the colloidal fractions from the total As in $<700 \mathrm{~nm}$ fraction (Table 1).

Dissolved fractions accounted for the majority of As in YC-1, YC-5 and MLW-7 yet most Fe was found as colloids (Table 1). The medium sized colloidal fraction (16-64 nm) accounted for $12.3 \%\left(19.4 \mu \mathrm{g} \mathrm{L}^{-1}\right)$, $12.3 \%\left(29.3 \mu \mathrm{g} \mathrm{L}^{-1}\right)$ and $13.4 \%\left(34.7 \mu \mathrm{g} \mathrm{L}^{-1}\right)$ of total As concentrations in three samples.

Fractograms from the FlFFF analysis suggested that humic-like DOM (represented by Ex/Em of $350 \mathrm{~nm} / 450 \mathrm{~nm}$ ) in smaller molecular size, mostly $<3 \mathrm{~nm}$ but protein-like DOM (characterized by Ex/Em of $275 \mathrm{~nm} / 300 \mathrm{~nm}$ ) in a wider size spectrum containing both nano-colloidal $<4 \mathrm{~nm}$ and larger colloidal sizes in the $4-8 \mathrm{~nm}$ and $>20 \mathrm{~nm}$ levels. The different sized DOM components may have different affinity for different forms of As during their interactions, which can be elucidated by simultaneous analysis of both DOM and As in different molecular size fractions. Concerned with sample preservation artefacts, field ultrafiltration under $\mathrm{N}_{2}$ atmosphere will be employed during future sampling to evaluate reducing groundwater Asorganic matter interaction.
Table 1. Concentrations of selected elements of three samples in the $0.7 \mu \mathrm{m}, 0.4 \mu \mathrm{m}$ and $0.2 \mu \mathrm{m}$ filtrates (in blue), and $64-700 \mathrm{~nm}, 16-64 \mathrm{~nm}, 8-16 \mathrm{~nm}$ and $0.5-8 \mathrm{~nm}$ fractionations. The concentrations in the dissolved fraction $(<0.5 \mathrm{~nm})$ were estimated by subtracting the sum of all the colloidal fractions from the total concentrations in $<700 \mathrm{~nm}$ fraction.

\begin{tabular}{|c|c|c|c|c|c|c|}
\hline $\begin{array}{l}\text { Sample } \\
\text { ID }\end{array}$ & $\begin{array}{l}\text { Size } \\
\text { internal } \\
(\mathrm{nm})\end{array}$ & $\begin{array}{l}\text { As } \\
\left(\mu \mathrm{gL}^{-1}\right)\end{array}$ & $\begin{array}{l}\mathrm{Fe} \\
\left(\mathrm{mg} \mathrm{L}^{-1}\right)\end{array}$ & $\begin{array}{l}\mathrm{S} \\
\left(\mathrm{mg} \mathrm{L}^{-1}\right)\end{array}$ & $\begin{array}{l}\mathrm{Mn} \\
\left(\mathrm{mg} \mathrm{L}^{-1}\right)\end{array}$ & $\begin{array}{l}\mathrm{Mg} \\
\left(\mathrm{mg} \mathrm{L}^{-1}\right)\end{array}$ \\
\hline \multirow[t]{8}{*}{ YC-1 } & $<700$ & 157.5 & 1.52 & 242.9 & 0.09 & 97.5 \\
\hline & $<400$ & 163.3 & 2.54 & 240.2 & 0.31 & 97.2 \\
\hline & $<200$ & 168.2 & 1.69 & 236.6 & 0.23 & 95.7 \\
\hline & $64-700$ & 10.3 & 0.71 & 0.9 & 0.04 & 0.57 \\
\hline & $16-64$ & 19.4 & 0.53 & 2.0 & 0.03 & 0.46 \\
\hline & $8-16$ & 3.5 & 0.07 & 0.5 & 0.01 & 0.12 \\
\hline & $0.5-8$ & 1.7 & 0.10 & 1.1 & 0.00 & 0.14 \\
\hline & $<0.5$ & 122.6 & 0.11 & 238.4 & 0.01 & 96.2 \\
\hline \multirow[t]{8}{*}{ YC-5 } & $<700$ & 236.5 & 0.28 & 42.6 & 0.18 & 30.5 \\
\hline & $<400$ & 231.5 & 0.28 & 45.2 & 0.18 & 31.2 \\
\hline & $<200$ & 233.2 & 0.32 & 52.5 & 0.14 & 35.9 \\
\hline & $64-700$ & 12.8 & 0.08 & 0.0 & 0.01 & 0.08 \\
\hline & $16-64$ & 29.1 & 0.11 & 0.0 & 0.01 & 0.18 \\
\hline & $8-16$ & 13.9 & 0.01 & 44.6 & 0.00 & 0.04 \\
\hline & $0.5-8$ & 3.0 & 0.03 & 102.0 & 0.00 & 0.03 \\
\hline & $<0.5$ & 177.7 & 0.05 & -104.0 & 0.16 & 30.2 \\
\hline \multirow[t]{8}{*}{ MLW-7 } & $<700$ & 259.5 & 0.16 & 0.8 & 0.17 & 15.1 \\
\hline & $<400$ & 262.3 & 0.28 & 0.4 & 0.16 & 15.1 \\
\hline & $<200$ & 255.0 & 0.12 & 0.8 & 0.04 & 15.5 \\
\hline & $64-700$ & 13.9 & 0.14 & 0.8 & 0.01 & 0.07 \\
\hline & $16-64$ & 34.7 & 0.80 & 2.4 & 0.02 & 0.36 \\
\hline & $8-16$ & 14.9 & 3.0 & 0.2 & 0.12 & 0.08 \\
\hline & $0.5-8$ & 5.5 & 0.07 & 0.2 & 0.01 & 0.02 \\
\hline & $<0.5$ & 190.5 & -3.8 & -2.9 & 0.01 & 14.55 \\
\hline
\end{tabular}

\section{ACKNOWLEDGEMENTS}

The study is supported by National Natural Science Foundation (No. 41772265). Special thanks are extended to Tingwen Wu from China Geology Survey.

\section{REFERENCES}

Guo, H.M., Zhang, B. \& Zhang, Y. 2011. Control of organic and iron colloids on arsenic partition and transport in high arsenic groundwaters in the Hetao basin, Inner Mongolia. Appl. Geochem. 26(3): 360-370.

McArthur, J.M., Ravenscroft, P., Safiulla, S. \& Thirlwall, M.F. 2001. Arsenic in groundwater: testing pollution mechanisms for sedimentary aquifers in Bangladesh. Water Resour. Res. 37(1): 109-117.

Mladenov, N., Zheng, Y., Miller, M.P., Nemergut, D.R., Legg, T., Simone, B., Hageman, C., Rahman, M.M., Ahmed, K.M. \& McKnight, D.M. 2009. Dissolved organic matter sources and consequences for iron and arsenic mobilization in Bangladesh aquifers. Environ. Sci. Technol. 44(1): 123-128.

Sharma, P., Ofner, J. \& Kappler, A. 2010. Formation of binary and ternary colloids and dissolved complexes of organic matter, Fe and As. Environ. Sci. Technol. 44(12): 44794485 .

Wang, S.L. \& Mulligan, C.N. 2006. Effect of natural organic matter on arsenic release from soils and sediments into groundwater. Environ. Geochem. Heal. 28(3): 197-214. 


\title{
Sedimentological controls on the formation of high arsenic aquifers in the central Yangtze River Basin since the Last Glacial Maximum
}

\author{
Y. Deng ${ }^{1}$, Y.X. Wang ${ }^{2} \& \mathrm{~T} . \mathrm{Ma}^{2}$ \\ ${ }^{1}$ Geological Survey, China University of Geosciences, Wuhan, China \\ ${ }^{2}$ School of Environmental Studies, China University of Geosciences, Wuhan, China
}

\begin{abstract}
Understanding the mechanism of arsenic mobilization from sediments to groundwater is important for drinking water supply and water quality management in endemic arsenicosis areas, such as the Jianghan alluvial plain in the middle reaches of the Yangtze river. Sediment samples from three boreholes in Jianghan Plain were collected for bulk geochemistry analysis and OSL dating. Sedimentological processes and palaeoclimatic optima after the Last Glacial Maximum have created favorable conditions for the formation of high-As aquifer systems. Bulk sediment geochemistry results indicated that As was correlated with sulfur in the preLGM sediments and by contrast As was correlated with iron in the post-LGM sediments. The intense chemical weathering led to sulfur depletion after the LGM could contribute to the As enrichment in the Holocene and upper Pleistocene aquifer.
\end{abstract}

\section{INTRODUCTION}

Geogenic enrichment of arsenic (As) in groundwater has been a topic worldwide concerned over the past decades due to its severe health threat, which impact about one hundred million people. Within river systems draining the Himalaya, tectonic movement, sedimentological processes and palaeoclimatic optima after the Last Glacial Maximum have created favorable conditions for the formation of high-As aquifer systems mainly within the Late Pleistocene-Holocene deposits (McArthur et al., 2011; Wang et al., 2017). The Jianghan Plain located in the middle reach of the Yangtze River Basin in central China has been documented with severe As contamination in the shallow aquifers (Gan et al., 2014; Deng et al., 2018). However, the underlying mechanism responsible for the formation of high arsenic aquifers has not been clearly understood yet. This purpose of this study was to delineate the relationship between the effects of Quaternary sediment deposition responding to sea level change since the Last Glacial Maximum on the arsenic enrichment in the shallow aquifers in the Jianghan Plain.

\section{METHODS/EXPERIMENTAL}

\subsection{Study area}

Jianghan alluvial plain in Central China is located in the middle Reaches of the Yangtze River, formed by Yangtze River and its largest tributary the Han River (Fig. 1). It is well known as the beautiful and rich land of fish and rice. It has a sub-tropical monsoonal climate with an annual precipitation and evaporation of approximately $1200 \mathrm{~mm}$ and $1378 \mathrm{~mm}$, respectively.

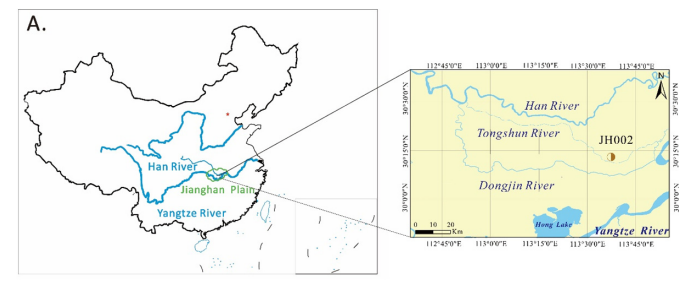

Figure 1. The geographical location of sampling borehole JH002 in the Jianghan Plain.

The Quaternary groundwater systems can be divided into three groups of aquifers. The first group is composed of Holocene alluvial and lacustrine deposits (clay, silt and fine sand) with a thickness of 3-10 m. The second group is composed of late and middle Pleistocene alluvial sediments (medium-coarse sand and gravel, interlaced clay lenses in local area) with a thickness of $30 \mathrm{~m}$; this is the main aquifer for water supply. The third group is composed of early Pleistocene alluvial sediments (fine-medium sand, interlaced clay lenses).

\subsection{Sampling and analysis}

Sediment samples from three boreholes with depths up to $230 \mathrm{~m}$ in typical arsenic-affected area were collected for bulk geochemistry analysis and $\mathrm{As}, \mathrm{Fe}$ and $\mathrm{S}$ speciation. Major-element analysis $\left(\mathrm{SiO}_{2}, \mathrm{Fe}_{2} \mathrm{O}_{3}\right.$, $\mathrm{Al}_{2} \mathrm{O}_{3}, \mathrm{Na}_{2} \mathrm{O}, \mathrm{CaO}, \mathrm{P}_{2} \mathrm{O}_{5}$, and $\mathrm{MgO}$ ) was done with an XRF spectrometer (RIX2100, Rigaku). Trace elements were determined using ICP-MS after a mixed acid $\left(\mathrm{HNO}_{3}-\mathrm{HClO}_{4}-\mathrm{HF}\right)$ digestion. Total carbon and sulfur, total organic carbon were measured using an Elemental Analyzer (Vario MICRO cube, Elementar). 

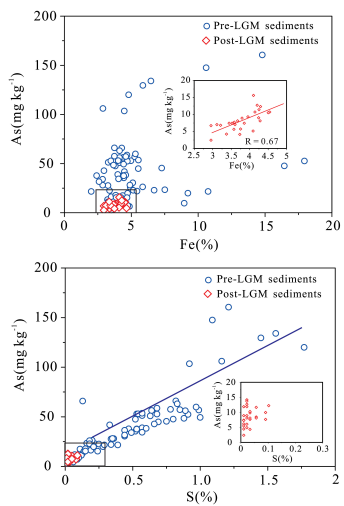

Figure 2. The relationship between arsenic and iron \& sulfur in pre-LGM and post-LGM sediments samples of JH002.

We used the optical stimulated luminescence (OSL) dating method to measure the age of 23 sediment samples with the depths from 3.25 to $45.3 \mathrm{~m}$ below ground surface (bgs).

\section{RESULTS AND DISCUSSION}

\subsection{Lithology and bulk geochemistry}

According to the lithology and grain size analysis, the Quaternary aquifers could be divided into the Holocene-upper Pleistocene phreatic aquifer $(15-60 \mathrm{~m})$ and middle-lower Pleistocene confined aquifer $(>60 \mathrm{~m})$. Bulk sediment geochemistry analysis showed that As, Fe, Mn, P, TOC contents in the sediments of middle-lower Pleistocene aquifer were much higher than those in the Holocene and upper Pleistocene aquifer. Arsenic sequential extraction and SEM-EDS analysis indicated that the shallow sediments possessed an average As content of $9 \mu \mathrm{g} \mathrm{g}^{-1}$. Arsenic content in the groundwater was up to $2330 \mu \mathrm{g}$ $\mathrm{L}^{-1}$. The deep aquifer possessed an average As content of $55 \mu \mathrm{g} \mathrm{g}^{-1}$, and the highest As content in the groundwater was about $100 \mu \mathrm{g} \mathrm{L}^{-1}$. Arsenic was correlated with sulfur in the pre-LGM sediments $(\mathrm{R}=0.7$, $\mathrm{P}<0.05)$ and the pyrite was observed to be the main sink of As in the deep aquifer $(>60 \mathrm{~m})$, by contrast arsenic was correlated with iron in the post-LGM sediments ( $\mathrm{R}=0.67, \mathrm{P}<0.05)$ (Fig. 2).

Iron sequential extraction results indicated that $\mathrm{Fe}$ mainly existed as iron-oxides in Holocene and upper Pleistocene sediments, while the siderite was the main form of in middle-lower Pleistocene sediments. In addition, abundant $\mathrm{Fe}$ in pyrite-form were observed in some sulfur riched samples in middle-lower Pleistocene sediments.

\subsection{Sedimentological controls on the enrichment of arsenic in shallow aquifers since the LGM}

Sea level in the Last Glacial Maximum was $120 \mathrm{~m}$ lower than today, which led to depositional break during 40-20 ka. In warming period, the sea level raised immediately, with a quick response of the Yangtze

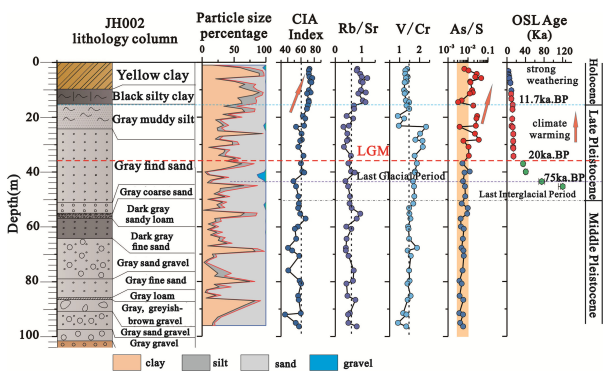

Figure 3. The variation of particle size, CIA index and As/S mole ratio in sediment samples of JH002 borehle.

river. The high $\mathrm{CIA}, \mathrm{Rb} / \mathrm{Sr}$ and $\mathrm{V} / \mathrm{Cr}$ values indicated an intense chemical weathering and oxidizing sedimentary environment in post-LGM period. The mole ratio of $\mathrm{As} / \mathrm{S}$ in the post-LGM sediments was $>0.01$, while in the deep pre-LGM sediments, the As/S kept stable and ranged between 0.0032 and 0.0061 (Fig. 3). Arsenic enriched in the shallow aquifer during post-LGM period may be caused by the intense chemical weathering of arsenopyrite in the sediments after the LGM.

\section{CONCLUSIONS}

The bulk sediments geochemistry indicated that As was correlated with sulfur in the pre-LGM sediments and by contrast arsenic was correlated with iron in the post-LGM sediments. The intense chemical weathering leading to sulfur depletion after the Last Glacial Maximum could contribute to the As enrichment in the Holocene and upper Pleistocene aquifer.

\section{ACKNOWLEDGEMENTS}

The research was financially supported by the National Natural Science Foundation of China (Nos. 41572226 \& 41521001), Program of China Geological Survey (Nos. 121201001000150121).

\section{REFERENCES}

Gan, Y.Q., Wang, Y.X., Duan Y.H., Deng, Y.M., Guo, X.X. \& Ding, X.F. 2014. Hydrogeochemistry and arsenic contami-nation of groundwater in the Jianghan Plain, central China. J. Geochem. Explor. 138(3): 81-93.

Deng, Y.M., Zheng, T.L., Wang, Y.X., Liu, L., Jiang, H.C. \& Ma, T. 2018. Effect of microbially mediated iron mineral transformation on temporal variation of arsenic in the Pleistocene aquifers of the central Yangtze River basin. Sci. Total Environ. 619-620C: 1247-1258.

McArthur, J.M., Nath, B., Banejee, D.M., Purohit, R. \& Grassineau, N. 2011. Palaeosol control on groundwater flow and pollutant distribution: the example of arsenic. Environ. Sci. Technol. 45: 1376-1383.

Wang, Y.X., Pi, K.F., Fendorf, S., Deng, Y.M. \& Xie, X.J. 2017. Sedimentogenesis and hydrobiogeochemistry of high arsenic late pleistocene-holocene aquifer systems. Earth Sci. Rev. DOI:10.1016/j.earscirev.2017.10.007 


\title{
Roles of dissolved organic matter on seasonal arsenic variation in shallow aquifers of the central Yangtze River Basin by EEM-PARAFAC analysis
}

\author{
X.F. Yuan, Y. Deng \& Z.J. Lu \\ Geological Survey, China University of Geosciences, Wuhan, P.R. China
}

\begin{abstract}
Fluorescence excitation-emission matrix (EEM) analysis was applied to characterize seasonal variation of dissolved organic matter (DOM) in arsenic-affected shallow aquifers of the Jianghan Plain, central China, to better understand the effect of DOM on arsenic transformation during dry season and wet season. It was identified that there are three components of DOM, of which $\mathrm{C} 1$ and $\mathrm{C} 3$ are fulvic acid-like substances and $\mathrm{C} 2$ is humic acid substance, and there is no obvious seasonal variability in $\mathrm{C} 2$, and the concentration is slightly higher in the wet season than the dry season. $\mathrm{C} 1$ and $\mathrm{C} 3$ have the opposite change rules in different seasons, which is mainly reflected in the shallow unconfined water.
\end{abstract}

\section{INTRODUCTION}

Naturally arsenic (As) enrichment of groundwater is a subject of great concern, which has been reported from numerous countries worldwide (Keon et al., 2001; Smedley et al., 2002). China is one of the most serious waterborne endemic arsenicosis affected area. Jianghan Plain is a newly discovered arsenic affected area in Southern China. Fluorescence spectroscopy is a simple, sensitive and nondestructive technique that can provide valuable information regarding the molecular structure of dissolved organic matter (DOM) present in natural waters and generate 3-D excitation emission matrices (EEMs) spectra of DOM. PARAFAC can be applied to decompose fluorescence EEMs into different independent groups of fluorescent components, which can then reduce the interference among fluorescent compounds (Engelen et al., 2009; Chen et al., 2010). In this paper, we reveal the temporal changes of DOM and the relationships among DOM and As.

\section{METHODS}

\subsection{Study area}

Jianghan alluvial plain in Central China is located in the middle Reaches of the Yangtze River, formed by Yangtze River and its largest tributary Han River. A total of 39 monitoring wells with three different depths were installed at 13 sites in Shahu monitoring field site of Jianghan plain. At each site, three monitoring wells with $10 \mathrm{~m}(\mathrm{~A}), 25 \mathrm{~m}(\mathrm{~B})$, and $50 \mathrm{~m}$ (C) deep tapped shallow aquifers composed of Quaternary deposits.

\subsection{Sampling and analysis}

Samples were collected in Jan 2016 to Jul 2016 in Shahu monitoring field site of the Jianghan Plain. Some in-situ parameters including $\mathrm{T}\left({ }^{\circ} \mathrm{C}\right), \mathrm{EC}, \mathrm{DO}$, Eh, $\mathrm{pH}, \mathrm{S}^{-}, \mathrm{NH}_{4}^{+}$and $\mathrm{Fe}^{2+}$ were monitored and in-situ measured when sampling. Water samples were also collected for further laboratory analysis, including major and trace elements, dissolved organic carbon (DOC) and 3-D fluorescence spectra analysis. Two multivariate statistical techniques including FA and PARAFAC were applied to hydrochemical variables and EEMs of groundwater, respectively.

\section{RESULTS AND DISCUSSION}

\subsection{Water-level fluctuation and As temporal variation}

The water level between the wet and dry season fluctuates about $1 \mathrm{~m}$. Arsenic has a temporal variation in shallow aquifers, and has a relationship with water level, ORP and DOC (Fig. 1).

\subsection{Fluorescence characteristics of DOM by PARAFAC analysis}

By PARAFAC of samples, it can be identified that there are three components of DOM (Fig. 2), of which $\mathrm{C} 1$ and $\mathrm{C} 3$ are fulvic acid-like substances and $\mathrm{C} 2$ is humic acid substance. The main components of DOM in surface water are $\mathrm{C} 1$ and $\mathrm{C} 3$, whilst the $\mathrm{DOM}$ in groundwater are mostly $\mathrm{C} 1$ and $\mathrm{C} 2 . \mathrm{C} 1$ and $\mathrm{C} 3$ are terrestrial organic matter, the smallest molecule produced in the process of microbial degradation. $\mathrm{C} 2$ is the DOM 

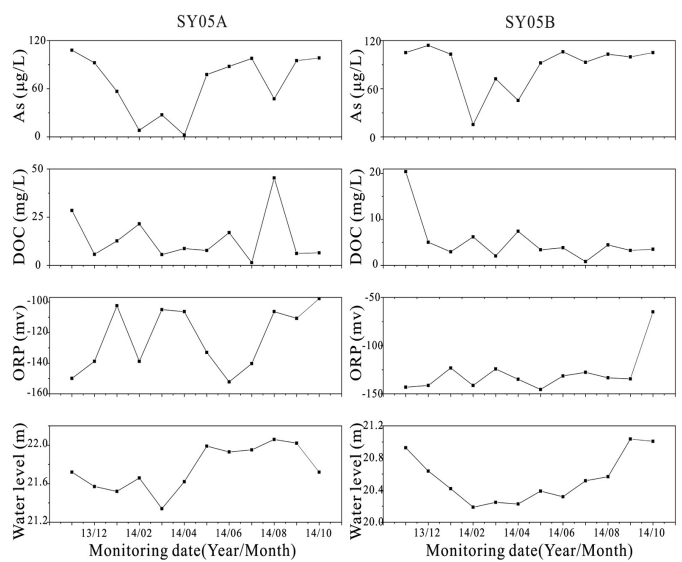

Figure 1. The generalization of As temporal variation with the water level, ORP and DOC in the aquifer of the Jianghan Plain, central Yangtze River Basin.
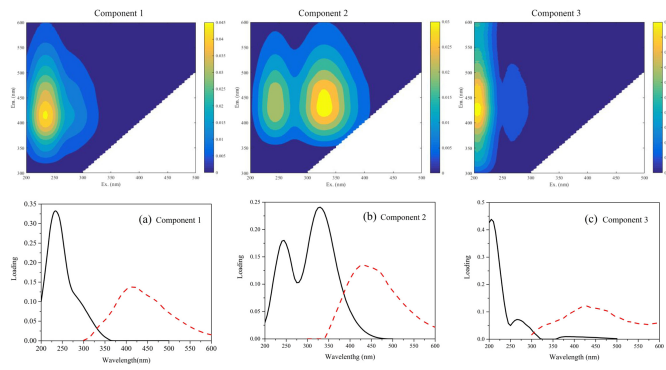

Figure 2. Excitation-emission matrices (EEMs) of groundwater components and spectral characteristics of three-component PARAFAC model validated by split half validation technique.

hybrid component of terrestrial materials, and marine materials and marine organic matter is considered to be the product of microbial utilization. There is no obvious seasonal variability in $\mathrm{C} 2$, and the concentration is slightly higher in the wet season than the dry season. $\mathrm{C} 1$ and $\mathrm{C} 3$ have the opposite change rules in different seasons, which is mainly reflected in the shallow unconfined water. The trend of arsenic concentration changes is the opposite of $\mathrm{C} 1$ and $\mathrm{C} 3$ (Table 1). The FI index in the sample groundwater is between 1.2 and 1.35 , also indicating that the DOM is mainly a terrestrial source, but there is also a mixture of terrestrial source and microbial source, which could come from sediment in the local aquifer.
Table 1. The changes of fluorescence component $\mathrm{C} 1, \mathrm{C} 2$, and $\mathrm{C} 3$ in shallow unconfined water and shallow confined water of Fmax value in dry season and wet season.

\begin{tabular}{|c|c|c|c|c|c|c|c|}
\hline & & \multicolumn{3}{|c|}{ Dry Season } & \multicolumn{3}{|c|}{ Wet Season } \\
\hline \multicolumn{2}{|c|}{ Monitoring Wells } & $\mathrm{C} 1$ & $\mathrm{C} 2$ & $\mathrm{C} 3$ & $\mathrm{C} 1$ & $\mathrm{C} 2$ & $\mathrm{C} 3$ \\
\hline Shallow & $01 \mathrm{~A}$ & 266 & 126 & 58 & 0 & 140 & 69 \\
\hline Unconfined & $03 \mathrm{~A}$ & 232 & 146 & 70 & 37 & 154 & 96 \\
\hline \multirow[t]{2}{*}{ Water } & $05 \mathrm{~A}$ & 132 & 47 & 16 & 121 & 50 & 115 \\
\hline & $07 \mathrm{~A}$ & 109 & 33 & 0 & 139 & 54 & 39 \\
\hline Shallow & $01 \mathrm{~B}$ & 153 & 60 & 42 & 129 & 69 & 119 \\
\hline Confined & 03B & 151 & 62 & 41 & 130 & 55 & 115 \\
\hline \multirow[t]{2}{*}{ Water } & $05 \mathrm{~B}$ & 240 & 119 & 82 & 0 & 113 & 67 \\
\hline & 07B & 113 & 34 & 0 & 140 & 133 & 88 \\
\hline
\end{tabular}

\section{CONCLUSIONS}

There is an obvious seasonal variability of As, and its variation has relationship with the water-level, ORP, DOC.There is no obvious seasonal variability in $\mathrm{C} 2$, and the concentration is slightly higher in the wet season than the dry season. $\mathrm{C} 1$ and $\mathrm{C} 3$ have the opposite change rules in different seasons, which is mainly reflected in the $10 \mathrm{~m}$ monitoring well.

\section{ACKNOWLEDGEMENTS}

The research was financially supported by the National Natural Science Foundation of China (Nos. 41572226 \& 41521001), and State Key Laboratory of Biogeology and Environmental Geology (No. 128-GBL21711), China University of Geosciences.

\section{REFERENCES}

Chen, M.L., Price, R.M., Yamashita, Y. \& Jaffe R. 2010. Comparative study of dissolved organic matter from groundwater and surface water in the Florida coastal Everglades using multidimensional spectrofluorometry combined with multivariate statistics. Appl. Geochem. $25: 872-880$.

Engelen, S., Frosch, S. \& Jorgensen, B.M. 2009. A fully robust PARAFAC method for analyzing fluorescence data. J. Chemom. 23:124-131.

Keon, N.E., Swartz, C.H., Brabander, D.J., Harvey, C. \& Hemond, H.F. 2001. Validation of an arsenic sequential extraction method for evaluating mobility in sediments. Environ. Sci. Technol. 35: 2778-2784.

Smedley, P.L. \& Kinniburgh, D.G. 2002. A review of the source, behavior and distribution of arsenic in natural waters. Appl. Geochem. 17: 517-568. 


\title{
Roles of iron and/or arsenic reducing bacteria in controlling the mobilization of arsenic in high arsenic groundwater aquifer
}

\author{
H. Liu, P. Li, Y.H. Wang \& Z. Jiang \\ State Key Laboratory of Biogeology and Environmental Geology, China University of Geosciences, \\ Wuhan, P.R. China
}

\begin{abstract}
To investigate microbial mediated As release and mobilization in the high arsenic groundwater, indigenous iron/As reducing bacteria were isolated from high arsenic groundwater in the Hetao Basin of Inner Mongolia in China. These isolates were identified to be Fe(III) and As(V) reducing (IAR) Shewanella putrefaciens IAR-S1, Fe(III) reducing (IR) S. xiamenensis IR-S2 and Klebsiella oxytoca IR-ZA, and As(V) reducing (AR) Citrobacter freundii AR-C1, Paralostridium bifermentans AR-P1, Klebsiella pneumoniae AR-K1 and Aeromonas hydrophila AR-A1. The incubation results showed that strains IAR-S1, IR-S2 and the control S. oneidensis MR-1 reduced ferrihydrite quickly and re-immobilized As. Strains AR-C1, AR-P1, AR-K1 and AR-A1 reduces $\mathrm{As}(\mathrm{V})$ to As(III), and arsenic (As-tot) was released into the aqueous phase with strain IR-ZA and strain AR-C1.
\end{abstract}

\section{INTRODUCTION}

Arsenic (As) as a toxic metalloid element threatens the health of more than 140 million people worldwide. It is well known that microbes play an important role on mediating As-bearing Fe(III) oxyhydroxides reduction and As mobilization. Whether DIR results in As retention or release is still an international debate topic. Therefore, to investigate microbiallymediated DIR affecting on As release and mobilization in high arsenic groundwater environment in Hetao Basin of Inner Mongolia, the primary objectives of this study were to: 1) isolate and characterize the dissimilatory iron and/or arsenic reducing strains from the high arsenic groundwater area of Hetao Basin; 2) investigate the arsenic mobilization from As-bearing ferrihydrite with different strains.

\section{METHODS/EXPERIMENTAL}

\subsection{Site description and sample collection}

Water samples for bacterial isolation were collected from two tube wells in Hangjinghouqi County of Hetao Basin, where endemic arseniasis is most serious. Groundwater from this region contains high As concentrations up to $1.74 \mathrm{mg} \mathrm{L}^{-1}$.

\subsection{Bacterial isolation and identification Bacterial isolation and identification}

Iron-reducing medium (IRM) or chemically defined medium (CDM) were used to screen iron-reducing and arsenic-reducing bacteria. For isolation, the Hungate roll tube technique was used (Hungate, 1969). All transfers and cultures sampling were performed in an anaerobic chamber with tubes and bottles flushed with $\mathrm{O}_{2}$-free $\mathrm{N}_{2}$ gas.

DNA was extracted from over-night cultures using FastDNA ${ }^{\circledR}$ SPIN Kit for Soil according to manufacturer's protocols (Qbiogene, Inc. CA, USA) and 16S rRNA gene was amplified with the primers $27 \mathrm{~F}$ and 1492R. The 16S rRNA gene sequences were aligned with the closely related sequences in the GenBank database using the BLAST program.

\subsection{Arsenate and ferric reduction assays}

Iron and $\mathrm{As}(\mathrm{V})$ reduction activities of isolated strains were assayed with IRM or CDM, respectively, under anaerobic conditions as previously described by Dai et al. (2016).

$0.8 \mathrm{~mL}$ pre-culture of strain and As-bearing ferrihydrite (As/Fe molar ratios was $1 \%$ ) was transferred into $100 \mathrm{~mL}$ bottles with $80 \mathrm{~mL}$ basal medium (BM) under strictly anaerobic conditions and incubated at $30^{\circ} \mathrm{C}$ in dark with $120 \mathrm{rpm}$. The control experiment was conducted using an autoclaved abiotic sample under the same conditions to confirm only the chemical effect. In order to detect As mobilization with microbial DIR under groundwater conditions of our study area, strains were incubated with artificial groundwater medium (AGM) and natural groundwater instead of BM.

\section{RESULTS}

\subsection{Isolation and identification}

Three iron reducing strains were obtained and referred to as IAR-S1, IR-S2 and IR-ZA, respectively. BLAST analysis in GenBank identified that 
strain IAR-S1 belonged to Shewanella putrefaciens (99.57\%), strain IR-S2 belonged to Shewanellaxiamenensis (99.36\%), and strain IR-ZA belonged to Klebsiella oxytoca $(99.54 \%)$.

Four arsenate reducing strain was obtained and was named as AR-C1, AR-P1, AR-K1 and AR-A1. Phylogenetic analysis places these four strains closest to organisms referring to as Citrobacter freundii, Paralostridium bifermentans, Klebsiella pneumoniae and Aeromonas hydrophila with the similarity of $99.93 \%, 100 \%, 99.94 \%$ and $99.97 \%$, respectively.

\subsection{Iron and arsenic reduction assays}

Three Fe(III)-reducing strains IAR-S1, IR-S2 and IRZA performed relatively quick reducing rates in the initial 1.0 day, and then slowed down in the remaining incubation. Strain IAR-S1 has a comparatively strong iron reducing capability and could reduce $20.00 \mathrm{mM}$ $\mathrm{Fe}(\mathrm{III})$ into $\mathrm{Fe}(\mathrm{II})$ in 1.5 days, while both strain IR-S2 and IR-ZA only could reduce $16 \mathrm{mM}$ and $10 \mathrm{mM}$ in 1.5 days.

In CDM medium, strain AR-C1 could reduce $100 \%$ of $1 \mathrm{mM} \mathrm{As}(\mathrm{V})$ in $72 \mathrm{~h}$ and $75 \%$ of $2.5 \mathrm{mM} \mathrm{As}(\mathrm{V})$ in $120 \mathrm{~h}$ and $23.1 \%$ of $5 \mathrm{mM}$ in $48 \mathrm{~h}$. Strain AR-P1 could reduce $100 \%$ of $1 \mathrm{mMAs}(\mathrm{V})$ in $96 \mathrm{~h}, 77.6 \%$ of $2.5 \mathrm{mM}$ As(V) in $96 \mathrm{~h}$, and $36.9 \%$ of $5 \mathrm{mMAs}(\mathrm{V})$ in $72 \mathrm{~h}$. Strain AR-K1 could reduce $100 \%$ of $1 \mathrm{mM} \mathrm{As}(\mathrm{V})$ in $48 \mathrm{~h}$, $55.8 \%$ of $2.5 \mathrm{mM} \mathrm{As}(\mathrm{V})$ in $84 \mathrm{~h}$, and $33.7 \%$ of $5 \mathrm{mM}$ $\mathrm{As}(\mathrm{V})$ in $48 \mathrm{~h}$. Strain AR-A1 could reduce $100 \%$ of $1 \mathrm{mM} \mathrm{As}(\mathrm{V})$ in $48 \mathrm{~h}, 70.8 \%$ of $2.5 \mathrm{mM} \mathrm{As}(\mathrm{V})$ in $60 \mathrm{~h}$, and $38.3 \%$ of $5 \mathrm{mM} \mathrm{As}(\mathrm{V})$ in $48 \mathrm{~h}$. However, strain IR-S2 and IR-ZA did not show any As(V) reducing ability. IAR-S1 produced $1.00 \mathrm{mM}$ As(III) within 1.0 days, which can reduce both $\mathrm{Fe}(\mathrm{III})$ and $\mathrm{As}(\mathrm{V})$ with glucose as a carbon source.

\subsection{Reduction of As $(V)$-bearing ferrihydrite}

S. oneidensis MR-1 was chosen as the positive control to detect the As mobilization from As-bearing ferrihydrite by DIR. Under $\mathrm{H}_{2} \mathrm{PO}_{4}^{-}$conditions, at the beginning of incubation, the concentration of aqueous total arsenic (As-tot) increased quickly by all strains. However, the decrease of As-tot was observed along with the culture of strain IAR-S1, IR-S2 and MR-1 after the peaks appeared. The fluctuation of As concentration might be due to the aqueous As captured by the

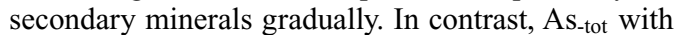
strain IR-ZA and AR-C1 was gradually increased after 12.0 days incubation. The As release with strain IR-ZA could be attributed to the decrease of the surface area of ferrihydrite with the reductive dissolution. On the other hand, more mobile As(III) produced by the As reducing strain AR-C1 increased the aqueous As.

Strains IAR-S1, IR-S2, IR-ZA AR-C1 and MR-1 incubated in the $\mathrm{HCO}_{3}^{-}$conditions, the AGM and the natural groundwater, also performed similar As release and $\mathrm{As}(\mathrm{III})$ reduction patterns with those of $\mathrm{H}_{2} \mathrm{PO}_{4}^{-}$. However, the concentrations of aqueous $\mathrm{As}_{\text {-tot }}$ released by strains were much lower than those of $\mathrm{H}_{2} \mathrm{PO}_{4}^{-}$.

\subsection{Effect of $A s(V)$-reduction or $A s(V)$ concentration on DIR}

To detect the effect of microbial Fe(III) and As(V) reductions on each other, $\mathrm{As}(\mathrm{V})$ reducing strain $\mathrm{AR}-\mathrm{C} 1$ and $\mathrm{Fe}$ (III) reducing strains IR-ZA and IR-S2 (without $\mathrm{As}(\mathrm{V})$ reducing capability) were chosen to co-incubate with As-bearing ferrihydrite. Results showed that both $\mathrm{Fe}(\mathrm{III})$ and $\mathrm{As}(\mathrm{V})$ reductions were improved in the coincubation. $\mathrm{Fe}(\mathrm{II})$ concentrations produced by strains AR-C 1 and IR-ZA after 8.0 days was $0.52 \mathrm{mM}$ higher than sole incubation of strain IR-ZA. More $0.33 \mathrm{mM}$ of $\mathrm{Fe}$ (II) were detected after 8.0 days co-culture of strains AR-C1 and IR-S2, which is higher than sole incubation of strain IR-S2. Aqueous As -tot $_{\text {concentra- }}$ tions increased with co-incubation of strain IR-ZA and AR-C1 after 18.0 days incubation, which is higher than the separated incubation of these two strains.

The effect of $\mathrm{As}(\mathrm{V})$ on DIR was also investigated, through incubation strain IR-S2 with different As/Fe molar ratio of As(V)-bearing ferrihydrite. The quantity of $\mathrm{Fe}$ (II) release was found to increase with the $\mathrm{As} / \mathrm{Fe}$ molar ratio of ferrihydrite. No Fe release or reduction was observed in the blank control.

\section{CONCLUSIONS}

Our results suggested that the microbial DIR in the groundwater aquifer enhance not only the release but also retention of arsenic. $\mathrm{Fe}(\mathrm{III})$ and $\mathrm{As}(\mathrm{V})$ reductions mediated by the indigenous bacteria were improved each other. Both microbial As reduction and reductive dissolution of $\mathrm{Fe}(\mathrm{III})$ oxyhydroxides were important mechanisms of As enrichment in groundwater aquifers in the Hetao Basin of Inner Mongolia.

\section{ACKNOWLEDGEMENTS}

The research work was financially supported by the National Natural Science Foundation of China (No. 41521001 and No.41772260).

\section{REFERENCES}

Dai, X.Y., Li, P., Tu, J., Zhang, R., Wei, D.Z., Li, B., Wang, Y.H. \& Jiang, Z. 2016. Evidence of arsenic mobilization mediated by an indigenous iron reducing bacterium from high arsenic groundwater aquifer in Hetao Basin of Inner Mongolia, China. Int. Biodeter. Biodegr. 128: 22-27.

Hungate, R.E. 1969. Chapter IV A roll tube method for cultivation of strict anaerobes. Method Microbiol. 3: 117-132. 


\title{
The DOM characteristic in As-affected aquifer of Chaobai River in the North China Plain
}

\author{
Y.F. Jia ${ }^{1,2} \&$ Y.H. Jiang ${ }^{1,2}$ \\ ${ }^{1}$ State Key Laboratory of Environmental Criteria and Risk Assessment, Chinese Research Academy of Environmental \\ Sciences, Beijing, P.R. China \\ ${ }^{2}$ State Environmental Protection Key Laboratory of Simulation and Control of Groundwater Pollution, \\ Chinese Research Academy of Environmental Sciences, Beijing, P.R. China
}

\begin{abstract}
High As groundwater was found in Chaobai River aquifers of North China Plain (NCP) which poses risk to drinking water resource. Arsenic shows patchy distribution in both horizontal and vertical profiles with concentration of $<0.1-304 \mu \mathrm{g} \mathrm{L}^{-1}$. The enrichment of As is related to reductive dissolution, supported by contradictory distribution of As and $\mathrm{NO}_{3}^{-}$, negative correlation between $\mathrm{As}$ and $\mathrm{SO}_{4} / \mathrm{Cl}$, and positive and then negative trend between As and Fe. DOM decomposition was evidenced by positive link between As and P. Four florescence components were identified in groundwater DOM including humic acid-like, fulvic acid-like and two kinds of protein-like substances. Arsenic concentration shows negative correlation with humic substances (HS) except for the sample with the highest As. It seems that HS may enhance As mobilization possibly via electron shuttle or complexation effect only when it is in high content. The river water which is characterized with high humic-like substances would infiltrate to supply more HS to groundwater and further promotes As mobilization.
\end{abstract}

\section{INTRODUCTION}

High arsenic (As) groundwater is a worldwide environment issue, of which mostly occurred in reducing condition with dissolved organic matter (DOM) prevailing. Reactive DOM is believed to stimulate dissimilatory reduction of iron oxides/hydroxides which is accompanied by $\mathrm{As}(\mathrm{V})$ reduction and release of $\mathrm{As}(\mathrm{III})$. Recently, humic substance (HS) which is a large proportion of DOM is regarded as electron shuttle to enhance $\mathrm{Fe}$ (III) reduction and As release in Bangladesh aquifers (Mladenov et al., 2015). Based on these findings, DOM characterization in high Asaffected aquifers seems to be the first step to identify these processes. In this study, Chaobai River Watershed which was found to have high As groundwater was selected to see As mobilization patterns and related DOM characteristic in aquifers.

\section{MATERIALS AND METHODS}

\subsection{The study area}

The Chaobai River originating in Northern Yanshan Mountain flows through Beijing, Hebei and Tianjin and terminates to the Bohai Sea. It lies in the northern part of North China Plain (NCP) with prevailing semiarid and semi-humid climates. The annual precipitation and water surface evaporation are around $560 \mathrm{~mm}$ and $1100 \mathrm{~mm}$, respectively. Sand and partly gravel prevails in this Holocene porous aquifer. Precipitation and river water infiltration are the main recharge sources for groundwater. The need for drinking water causes a large amount of abstraction further the decline of groundwater table which shows an average rate of $2.8 \mathrm{~m} \mathrm{yr}^{-1}$ in part of area. The study area is located in the upper reach of the river known as the Shunyi district of Beijing. One major drinking water plant is located in this area, indicating an urgent need to deal with the groundwater quality problem and its further evolution.

\subsection{Sampling and analysis methods}

Sixty groundwater samples were collected from wells at depths of $30,50,80$ and $150 \mathrm{~m}$ as well as 6 surface river water samples. Major anions were determined using Ion Chromatography (DX-120, Dionex), major cations, $\mathrm{Fe}, \mathrm{Mn}$ and $\mathrm{As}$ by Inductively Coupled Plasma Atomic Emission Spectroscopy (iCAP 6300, Thermo). Fluorescence spectroscopy was determined using a Hitachi F-7000 fluorescence spectrophotometer. Three-dimensional fluorescence excitation emission matrices (EEMs) were generated by scanning samples over an excitation range of 200$450 \mathrm{~nm}$ at $5 \mathrm{~nm}$ increments and an emission range of $280-550 \mathrm{~nm}$ at $5 \mathrm{~nm}$ increments. Hierarchical cluster analysis (HCA) was performed on all samples with Ward's method, which uses the squared Euclidean distance as a similarity measure. 


\section{RESULTS AND DISCUSSION}

\subsection{As mobilization patterns}

Arsenic shows patchy distribution with concentration of $<0.1-304 \mu \mathrm{g} \mathrm{L}^{-1}$. Eleven of total 60 samples have As $>10 \mu \mathrm{g} \mathrm{L}^{-1}$, of which 7 above $50 \mu \mathrm{g} \mathrm{L}^{-1}$. Arsenic concentration in river water is below the detection limit. High arsenic groundwater was observed in all depth range, indicating a heterogeneous aquifer environment or the different influence of river water infiltration. Nitrate shows high and varied concentration in groundwater $\left(<0.1-90.4 \mathrm{mg} \mathrm{L}^{-1}\right)$ as well as the river water $\left(1.43-93.0 \mathrm{mg} \mathrm{L}^{-1}\right)$. Contradictory distribution was found between $\mathrm{As}$ and $\mathrm{NO}_{3}^{-}$with high As groundwater $\left(>10 \mu \mathrm{g} \mathrm{L}^{-1}\right)$ have $\mathrm{NO}_{3}^{-}$all below $6 \mathrm{mg} \mathrm{L}^{-1}$. Although As specie is not determined, it could be concluded that As(III) is more likely to be dominant. Arsenic shows a positive correlation with aqueous $\mathrm{Fe}$ when As below $100 \mu \mathrm{gL}^{-1}$, however reverse trend was found between them when As is higher, which is similar with the case in Hetao Basin (Jia et al., 2014). An obvious decline trend of $\mathrm{SO}_{4} / \mathrm{Cl}$ ratio was observed when As concentration increases. Total $\mathrm{P}$ showed liner and positive correlation with As when As $>10 \mu \mathrm{g} \mathrm{L}^{-1}$. These distribution patterns of As and other redox-sensitive components clearly indicate the scenario of reductive dissolution of $\mathrm{Fe}$ and related As release (Jia et al., 2017). DOM decomposition plays a critical role in this process and regulating As release.

\subsection{DOM character in high and low As groundwater}

Fluorescence spectroscopy helps to reveal different kind of DOM components. EEMs were delineated into five excitation-emission regions including Region I, II being aromatic protein-like, Region III fulvic acidlike, Region IV soluble microbial by-product-like, and Region V humic acid-like (Chen et al., 2003). The volume of each region represents the cumulative fluorescence response of DOM with similar properties. Generally, As concentration shows positive correlation with total volume of region I, II, and IV, while negative correlation with total volume of region III and $\mathrm{V}$ known as HS except for the sample with the highest As. It is dominated by humic acid-like substances, which account for $83.3 \%$ of total 5 regions volume. The volume of region $\mathrm{V}$ in this sample is the highest value of all samples as well. Therefore, it seems to be ineffective to As mobilization when humic acid-like substances is not in high content. Similar case shows at least $5 \mathrm{mg} \mathrm{L}^{-1} \mathrm{HS}$ is needed to stimulate microbial ferrihydrite reduction (Jiang et al., 2008).

Four florescence components were identified by EEM spectra coupled with PARAFAC analysis. It shows that components 1 and 2 are originated from humic acid-like, and fulvic acid-like substances, respectively, while components 3 and 4 from proteinlike substances. Arsenic concentration shows negative correlation with HS (components 1 and 2) except for the highest As sample. However, no significant pattern were found between As and protein-like substances (components 3 and 4).

\section{CONCLUSIONS}

This is just a preliminary analysis of DOM in high As aquifers in Chaobai River. The enrichment of As is related to reducing environment attributed by DOM decomposition. However, the specific component of DOM working for this process was not identified. HS may impact As mobilization explained as electron shuttle or complexation effect. However, in this area it may need to be in high content before it works. The concerning thing is that river water which is characterized with high humic-like substances would infiltrate to supply more HS to groundwater, its effect on As mobilization merit further investigation.

\section{ACKNOWLEDGEMENTS}

This work was supported by the National Water Pollution Control and Treatment Science and Technology Major Project (No. 2018ZX07109-003, 004).

\section{REFERENCES}

Chen, W., Westerhoff, P., Leenheer, J. A. \& Booksh, K. 2003. Fluorescence excitation-emission matrix regional integration to quantify spectra for dissolved organic matter. Environ. Sci. Technol. 37(24): 5701-5710.

Jia, Y.F., Guo, H.M., Jiang, Y.X., Wu. Y. \& Zhou, Y.Z. 2014. Hydrogeochemical zonation and its implication for arsenic mobilization in deep groundwaters near alluvial fans in the Hetao Basin, Inner Mongolia. J. Hydrol. 518: 410-420.

Jia, Y.F., Guo, H.M., Xi, B.D., Jiang, Y.H., Zhang, Z., Yuan, R.X., Yi, W.X. \& Xue, X.L. 2017. Sources of groundwater salinity and potential impact on arsenic mobility in the western Hetao Basin, Inner Mongolia. Sci. Total Environ. 601-602: 691-702

Jiang, J. \& Kappler, A. 2008. Kinetics of microbial and chemical reduction of humic substances: implications for electron shuttling. Environ. Sci. Technol. 42(10): 35633569.

Mladenov, N., Zheng, Y., Simone, B., Bilinski, T.M., McKnight, D.M., Nemergut, D., Radloff, K.A., Rahman M.M. \& Ahmed, K.M. 2015. Dissolved organic matter quality in a shallow aquifer of Bangladesh: implications for arsenic mobility. Environ. Sci. Technol. 49(18): 10815-10824. 


\title{
Sulfurated fertilizers enhance the microbial dissolution and release of arsenic from soils into groundwater by activating arsenate-respiring prokaryotes
}

\author{
X.C. Zeng, W.X. Shi, W.W. Wu \& S.G. Cheng \\ School of Environmental Studies, China University of Geosciences (Wuhan), Wuhan, Hubei, P.R. China
}

\begin{abstract}
This work aimed to investigate the activity and diversity of the dissimilatory arsenate-respiring prokaryotes (DARPs) in the paddy soils, and the effects of sulfate on the DARPs-catalyzed dissolution and release of arsenic and iron from paddy soils into aqueous phase. We collected arsenic-rich soils from a farmland region of the Xiantao city, Hubei, China. Microcosm assay was used to detect how DARPs catalyze the reduction, dissolution, and release of arsenic and iron from the soils, and how sulfate affects this microbial reaction. HPLCICP-MS technique was used to determine the arsenic and iron species. Quantitative PCR was used to measure the arsenate-respiring reductase gene abundances in the microcosms. We found that there are diverse DARPs in the indigenous microorganisms. Microcosm assays indicated that these DARPs efficiently promoted the mobilization, reduction and release of arsenic from soils under anaerobic condition. Remarkably, when sulfate was added into the reactions, the DARPs-mediated arsenic reduction and release were significantly increased. Agricultural activities may significantly promote arsenic-contamination in groundwater through increasing inputs of sulfate into paddy soils. It should be avoid overuses of sulfate fertilizers.
\end{abstract}

\section{INTRODUCTON}

Arsenic (As) is a highly toxic metalloid that is widely distributed in the environment. It can exist in organic or inorganic forms (Oremland et al., 2003; Zhu et al., 2014). It is present in more than 200 minerals, usually in combination with sulfur and metals (Kirk \& Holm, 2004; Smedley \& Kinniburgh, 2002; Ferguson et al., 1972). The most common arsenic-bearing mineral is arsenopyrite (Hao et al., 2014; Savage et al., 2004; Zhu et al., 2008). Arsenic typically occurs in four oxidation states: $-3,0,+3$ and +5 . The most dominant forms in arsenic-contaminated soils and water are As(III) (arsenite) and As(V) (arsenate). Arsenite is more soluble, mobile and toxic than arsenate. Arsenic compounds have been classified as a carcinogen to humans. Acute high-dose exposure to arsenic may cause severe systemic toxicity and death. Lowdose chronic exposure can result in cancers of various organs and tissues, hyperkeratosis, jaundice, neuropathy, diabetes mellitus, cardiovascular diseases, stroke, lung diseases, hepatotoxicity and other severe diseases (Zhu et al., 2014; Maguffin \& Kirk 2015; Singh et al., 2015)

Recently, it was found that high-arsenic groundwater exists in some areas in Jianghan Plain, China. A geochemical survey indicated that approximately $87 \%$ of the detected wells contained $10-2330 \mu \mathrm{g} \mathrm{L}^{-1}$ soluble arsenic. The sediments from the detected sites contained $10.73-136.72 \mathrm{mg} \mathrm{L}^{-1}$ adsorbed or mineral arsenic (Gan et al., 2014). More recently, we found that the microbial communities from deep sediments, instead of shallow soils, efficiently catalyzed the reduction, dissolution and release of arsenic from insoluble phase into groundwater (Chen et al., 2017). In this study, we aimed to explore how agricultural activities affect the arsenic mobilization and release from shallow soils into groundwater in Jianghan Plain. Because Jianghan Plain is one of the most important food grain production districts in China, sulfate fertilizers are widely used as essential $\mathrm{S}$ nutrients for the growth of crops. This significantly increased the sulfate contamination, suggesting that sulfate is one of the major environmental factors in the soils of this region. We found that sulfate has great effects on the indigenous microbial communities-catalyzed arsenic dissolution, reduction and release of arsenic from the paddy soils into groundwater. This finding provided direct evidence that anthropogenic agricultural activity significantly enhanced the arsenic contamination in groundwater.

\section{METHODS/EXPERIMENTAL}

We collected arsenic-rich soils from a farmland region of the Xiantao city, Hubei, China. Microcosm assay was used to detect how DARPs catalyze the reduction, dissolution, and release of arsenic and iron from the soils, and how sulfate affects this microbial reaction. HPLC-ICP-MS technique was used to determine the arsenic and iron species. Quantitative PCR was used to measure the arsenate-respiring reductase gene abundances in the microcosms. 

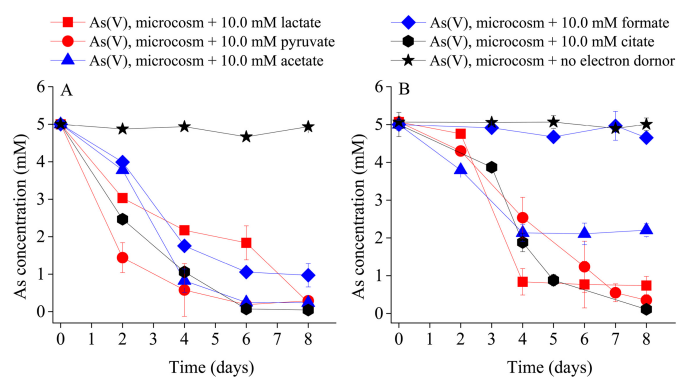

Figure 1. Arsenate-respiring reduction activities of the microbial communities from the sediment samples. Arsenate-respiring curve of the microcosm from the depth of $1.6 \mathrm{~m} \mathrm{(A)} \mathrm{and} 4.6 \mathrm{~m} \mathrm{(B).} \mathrm{Active} \mathrm{microcosms} \mathrm{of} \mathrm{the} \mathrm{two}$ samples were inoculated into the MM medium amended with $5.0 \mathrm{mM} \mathrm{As}(\mathrm{V})$ as the sole electron acceptor and $10.0 \mathrm{mM}$ lactate, formate, pyruvate, acetate or citrate as a electron donor

\section{RESULTS AND DISCUSSION}

\subsection{Arsenate-respiring activities of the microorganisms in the soils}

Microcosm assay was used to detect the arsenaterespiring activity of the microbial communities from the soils. The results showed that the arsenate-respiring activities were detectable in all of the two samples that were supplemented with different electron donors, and no significant arsenate-reducing activities were detected in the absence of external electron donors (Fig. 1).

\subsection{Unique diversity of the arsenate-respiring reductase genes from the soils}

To understand the molecular basis of the arsenaterespiring activities of the soils, we explored the molecular diversity of the arsenate-respiring reductase genes present in the microbial communities of the soils by cloning, sequencing and analyzing the arr $A$ marker sequence. We identified 27 novel arrA genes. Their encoded Arr proteins were referred to as M1 to M18 (from $1.6 \mathrm{~m}$ ), and $\mathrm{N} 1$ to $\mathrm{N} 8$ (from $4.6 \mathrm{~m}$ ). The amino acid sequences of these Arr proteins were each used as queries to search against the GenBank database using the BLAST sever. We found that the Arr proteins from the soils share $71-89 \%$ sequence identities with other known microbial Arr proteins, suggesting that a lot of new or new-type DARPs were present in the soils (Fig. 2).

\subsection{Microbial dissolution and release of As(III) and $\mathrm{Fe}(\mathrm{II})$ from the shallow soils}

To determine whether the microbial communities in the shallow soils are capable of catalyzing the arsenic

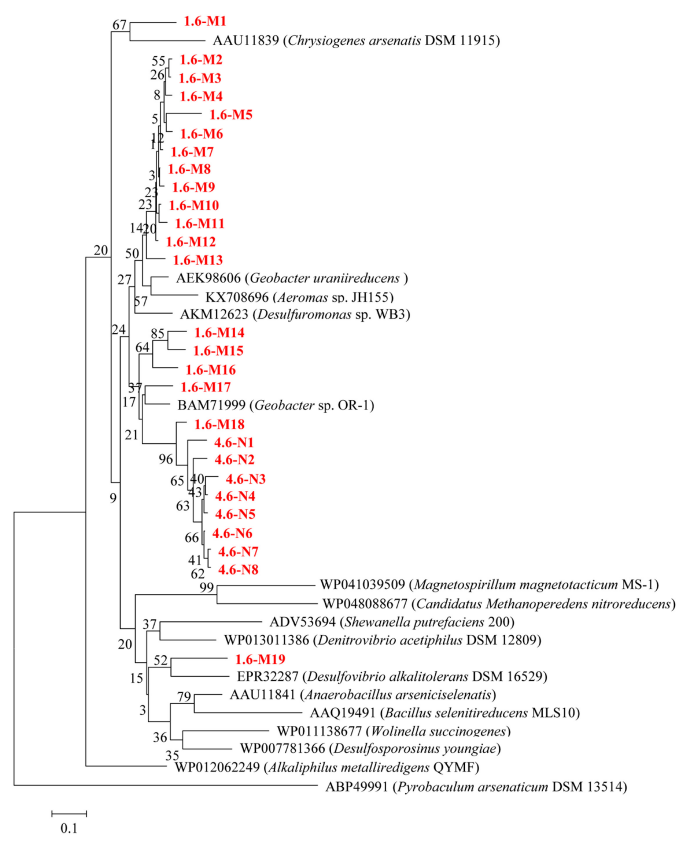

Figure 2. Phylogenetic analysis of arsenate-respiring reductases from the high-arsenic shallow sediments of Jianghan Plain.
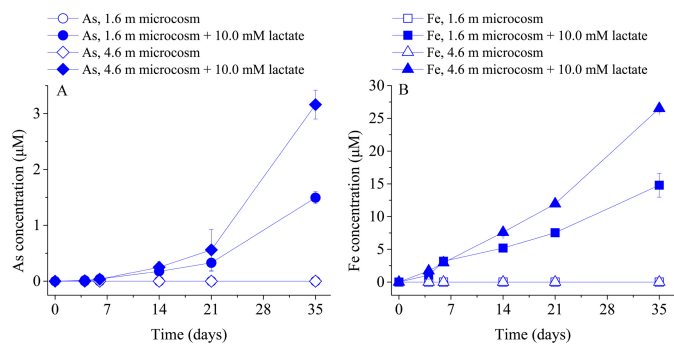

Figure 3. The mobilization, reduction and release of insoluble arsenic and iron catalyzed by microbial communities from the sediment samples using microcosm assay technique. The As(III) (A) and Fe(II) (B) release curves were achieved using the microcosms of the samples from the depth of $1.6 \mathrm{~m}$ and $4.6 \mathrm{~m}$. Active microcosms of the two samples were prepared by inoculating each of the samples into the synthetic groundwater supplemented with $10.0 \mathrm{mM}$ lactate.

release from insoluble phase, we conducted arsenic release assay using the soil samples under anaerobic condition.

These results suggest that the microorganisms in the soils of the depths 1.6 and $4.6 \mathrm{~m}$ significantly catalyzed the dissolution and release of arsenic and iron from the soils into aqueous phase, and the amount of the released iron was greater than that of the release arsenic. These data also indicated that there were more arsenic and iron released from the soils of $4.6 \mathrm{~m}$ than from those of $1.6 \mathrm{~m}$ (Fig. 3). 

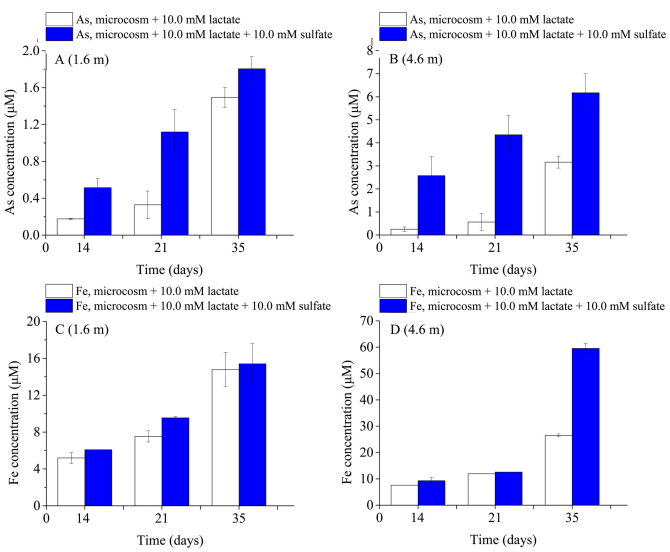

Figure 4. The mobilization, reduction and release of insoluble arsenic and iron catalyzed by microbial communities from the sediment samples in the presence of $10.0 \mathrm{mM}$ sulfate or without sulfate using microcosm assay technique. The As(III) and $\mathrm{Fe}$ (II) release curves were achieved using the microcosms of the samples from the depth of $1.6 \mathrm{~m}(\mathrm{~A}, \mathrm{C})$ and $4.6 \mathrm{~m}(\mathrm{~B}$, D). Active microcosms of the two samples were prepared by inoculating each of the samples into the synthetic groundwater supplemented with $10.0 \mathrm{mM}$ lactate and $10.0 \mathrm{mM}$ sulfate or without sulfate.

\subsection{Sulfate significantly enhanced the microorganisms-mediated release of arsenic and iron}

These results suggested that sulfate significantly enhanced the microorganisms-catalyzed dissolution, reduction and release of arsenic and iron from the soil phase (Fig. 4).

\subsection{Structures of the microbial communities from the soils}

To better understand the microbial basis of the observations, we analyzed the structures of the microbial communities from the soils using illumine high-throughout paired-end sequencing technique. We identified 39 phyla of bacteria.

As shown in Figure 5, the microbial community from the depth of $1.6 \mathrm{~m}$ consisted of Chloroflexi (38.16\% of the total microorganisms), Proteobacteria (25.07\%), Acidobacteria (10.00\%), Gemmatimonadetes (5.35\%), Latescibacteria (3.11\%), Aminicenantes (2.43\%), Nitrospirae (1.38\%), Actionbacteria (1.34\%), Firmicutes (1.00\%), Bacteroidetes $(0.35 \%)$, Spirochaetae $(0.34 \%)$, and other microorganisms with less abundance; the microorganisms from the depth of $4.6 \mathrm{~m}$ included Proteobacteria (50.77\%), Chloroflexi (15.38\%), Firmicutes (14.24\%), Nitrospirae (7.11\%), Bacteroidetes (6.17\%), Aminicenantes (2.97\%), Actionbacteria (2.51\%), Acidobacteria (1.94\%), Spirochaetae $(1.70 \%)$, candidate division Gal $15(1.53 \%)$, Gemmatimonadetes $(0.43 \%)$, Latescibacteria $(0.30 \%)$, and other less abundant microorganisms. This suggests that the microbial community structure from the depth

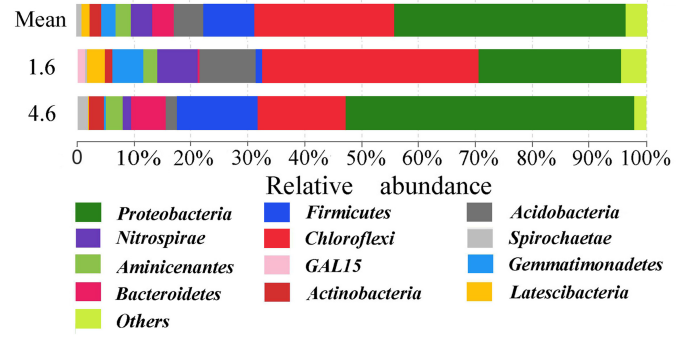

Figure 5. Analysis of the microbial community compositions of the sediment samples at phylum level from the Jianghan Plain.

$1.6 \mathrm{~m}$ significantly differs from that from the depth of $4.6 \mathrm{~m}$.

\section{CONCLUSIONS}

This study aimed to explore how arsenic was released from soil phase into groundwater, and how sulfate affects this bioprocess in Jianghan Plain, China. We found that a large diversity of DARPs are present in the shallow soils from the depths of 1.6 and $4.6 \mathrm{~m}$. Microcosm assays indicated that the microbial communities significantly catalyzed the dissolution, reduction and release of arsenic and iron from the soils into aqueous phase. It is interesting to see that addition of $10.0 \mathrm{mM}$ sulfate into the microcosms led to a significant increase of the microorganisms-mediated release of arsenic and iron from the soils. Quantitative PCR analysis for the functional gene abundances suggested that the sulfate-induced increase of microbial release of arsenic and iron was attributed to the significant enhancement of the DARP growth by sulfate. These results suggested that agricultural uses of sulfate fertilizers enhanced arsenic contamination in groundwater. The findings of this study gained new insight into the mechanisms by which the arsenic-contaminated groundwater was formed, and gave direct evidence that agricultural activities may enhance the arsenic contamination in groundwater.

\section{ACKNOWLEDGEMENTS}

This work was financially supported by the National Natural Science Foundation of China (grants no. 41472219, 41072181, 41272257 and 41521001).

\section{REFERENCES}

Chen, X.M., Zeng, X.C., Wang, J.N., Deng, Y.M., Ma, T., E.G.J., Mu, Y., Yang, Y., Li, H. \& Wang, Y.X. 2017. Microbial communities involved in arsenic mobilization and release from the deep sediments into groundwater in Jianghan plain, Central China. Sci. Total Environ. 579: 989-999.

Ferguson, J. F. \& Gavis, J. 1972. A review of the arsenic cycle in natural waters. Water Res. 6: 1259-1274. 
Gan, Y.Q., Wang, Y.X., Duan, Y.H., Deng, Y.M., Guo, X.X. \& Ding, X.F. 2014. Hydrogeochemistry and arsenic contamination of groundwater in the Jianghan Plain, central China. J. Geochem. Explor. 138: 81-93.

Hao, T.W., Xiang, P.Y., Mackey, H.R., Chi, K., Lu, H., Chui, H.K., van Loosdrecht, M.C.M. \& Chen, G.H. 2014. A review of biological sulfate conversions in wastewater treatment. Water Res. 65: 1-21.

Kirk, M.F., Holm, T.R., Park, J., Jin, Q.S., Sanford, R.A., Fouke, B.W. \& Bethke, C.M. 2004. Bacterial sulfate reduction limits natural arsenic contamination in groundwater. Geology 32: 953-956.

Maguffin, S.C., Kirk, M.F., Daigle, A.R., Hinkle, S.R. \& Jin, Q.S. 2015. Substantial contribution of biomethylation to aquifer arsenic cycling. Nat. Geosci. 8: 290-293.

Oremland, R.S. \& Stolz, J.F. 2003. The ecology of arsenic. Science 300(5621): 939-944.
Savage, K.S., Tingle, T.N., O’Day, P.A., Waychunas, G.A. \& Bird, D.K. 2004. Arsenic speciation in pyrite and secondary weathering phases, Mother Lode Gold District, Tuolumne County, California. Appl. Geochem. 15(8): 1219-1244.

Smedley, P.L. \& Kinniburgh, D.G. 2002. A review of the sources, behavior and distribution of arsenic in natural waters. Appl. Geochem. 17: 517-568.

Zhu, W., Young, L.Y., Yee, N., Serfes, M., Rhine, E.D. \& Reinfelder, J.R. 2008. Sulfide-driven arsenic mobilization from arsenopyrite and black shale pyrite. Geochim. Cosmochim. Acta. 72: 5243-5250.

Zhu, Y.G., Yoshinaga, M., Zhao, F.J. \& Rosen, B.P. 2014. Earth Abides Arsenic Biotransformations. Ann. Rev. Earth Planet. Sci. 42: 443-467. 
1.3 Biogeochemical processes controlling arsenic mobility, redox transformation and climate change impacts 


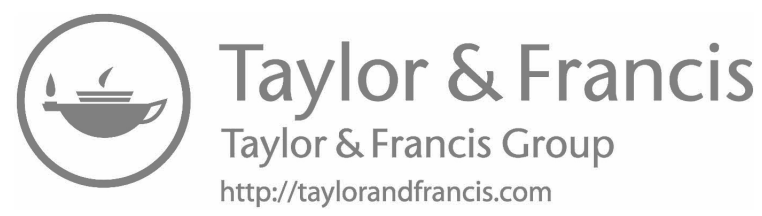




\title{
Structural insight into the catalytic mechanism of arsenate reductase from Synechocystis sp. PCC 6803
}

\author{
Y. Yan, J. Ye, X. Zhang, X.M. Xue \& Y.G. Zhu \\ Key Lab of Urban Environment and Health, Institute of Urban Environment, Chinese Academy of Sciences, \\ Xiamen, China
}

\begin{abstract}
Arsenate reductases are the key enzymes in biological arsenic detoxification by catalyzing the intracellular reduction of arsenate to arsenite, and arsenite could be subsequently pumped out of the cells by ArsB or Acr3. The arsenate reductase from cyanobacterium Synechocystis sp. Strain PCC 6803 (SynArsC) shows sequence homology with the thioredoxin-dependent arsenate reductase family, while utilizes the glutathione/glutaredoxin system for arsenate reduction. SynArsC is classified as a novel thioredoxin/glutaredoxin hybrid arsenate reductase family. Here we report the crystal structures of SynArsC in the native and phosphatebound states at 1.37 and $1.55 \AA$ resolutions, respectively. The structures are mostly similar, but also show differences with implications in SynArsC's arsenate reduction mechanism. Our results provide insights into SynArsC's structure-function relationship and its enzymatic mechanism.
\end{abstract}

\section{INTRODUCTION}

Arsenic is a toxic metalloid element that causes numerous environment and health problems. Ubiquitous arsenic forced living organisms to evolve different mechanisms for arsenic resistance. A two-step process, arsenate reduction followed by arsenite efflux, is a well-known mechanism of arsenate resistance (Zhu et al., 2017).

Cytoplasmic arsenate reductases (ArsC) are divided into at least three families (Messens \& Silver, 2006). The first family is represented by R773ArsC from Escherichia coli, which uses glutathione (GSH)/glutaredoxin (Grx) as electron donor and has a single catalytic cysteine. The second family is exemplified by SaArsC from Staphylococcus aureus, which uses thioredoxin $(\operatorname{Trx})$ as a reducing system and requires three cysteines for arsenate reduction. The last family is termed as Acr2P, and only present in eukaryotic organisms, such as Saccharomyces cerevisiae and Arabidopsis thaliana.

Arsenate reductase from Synechocystis $s p$. PCC 6803 (SynArsC) is a novel ArsC belonging to the Trx/Grx hybrid arsenate reductase family. The primary sequence of SynArsC is similar with that of Trxdependent ArsCs, whereas SynArsC utilized Grx/GSH system for arsenate reduction (López-Maury et al., 2009; Li et al., 2003). Cys8, Cys80 and Cys 82 in SynArsC were identified as essential cysteine residues by site-directed mutagenesis, and the Cys $80 / \mathrm{Cys} 82$ disulfide was detected by equilibrium redox titrations. In order to elucidate the special mechanism of $\mathrm{As}(\mathrm{V})$ reduction, we determined the crystal structures of native SynArsC and its complex with phosphate $\left(\mathrm{PO}_{4}^{3-}\right)$.

\section{METHODS/EXPERIMENTAL}

\subsection{Purification and crystallization}

SynArsC with his-tag was overexpressed in E. coli Rosetta (DE3), and purified by Ni-NTA agarose column and size-exclusion chromatography. Crystallization trials were set up at $291 \mathrm{~K}$ using hangingdrop vapor-diffusion method. The $2 \mu \mathrm{L}$ hanging drops consisted of $1 \mu \mathrm{L}$ protein solution and $1 \mu \mathrm{L}$ reservoir solution were equilibrated against $500 \mu \mathrm{L}$ reservoir solution $(32 \%(w / v)$ PEG 3350, $100 \mathrm{~m} M$ citric acid, $\mathrm{pH}$ 5.5). Needle-like crystals were observed after one week. As the co-crystallization of SynArsC and $\mathrm{As}(\mathrm{V}) / \mathrm{As}(\mathrm{III})$ was unsuccessful, we crystallized SynArsC with $\mathrm{PO}_{4}^{3-}$, an analog of $\mathrm{As}(\mathrm{V})$. The crystals of SynArsC- $\mathrm{PO}_{4}^{3-}$ were obtained in optimized reservoir solution consisting of $28 \%(w / v)$ PEG 3350, $100 \mathrm{~m} M$ citric acid and $\mathrm{pH} 4.8$ by adding $5 \mathrm{mM}$ $\mathrm{NaH}_{2} \mathrm{PO}_{4}$ into the protein solution. Crystals were mounted and soaked in corresponding reservoir solution supplemented with $20 \%$ glycerol and flash-cooled in liquid nitrogen prior to data collection.

\subsection{Data collection, structure determination and refinement}

Diffraction data were collected with a wavelength of $0.9792 \AA$ at $100 \mathrm{~K}$ on beamline BL17U of Shanghai Synchrotron Radiation Facility (SSRF). All data were indexed and integrated with iMosflm, and scaled with AIMLESS from CCP 4 program suite. The structures of native SynArsC and SynArsC-PO ${ }_{4}^{3-}$ were obtained by the molecular replacement method using Phaser. A single structure modified from the 20 conformers 
of NMR structure of SynArsC (Yu et al., 2011) was used as a search model. The structure models were built using Coot, and refined by iterative rounds of PHENIX automatically and Coot manually.

\section{RESULTS AND DISCUSSION}

\subsection{Determination of SynArsC structures}

The crystal structure of native SynArsC was determined in space group $P 22_{1} 2_{1} 2_{1}$, with unit-cell parameters $a=33.03, b=33.35, c=107.57 \AA$. The structure of SynArsC- $\mathrm{PO}_{4}^{3-}$ belonged to space group $C 121$, with unit-cell parameters $a=64.26, b=33.37$, $c=56.63 \AA, \beta=100.2^{\circ}$. The native SynArsC and SynArsC- $\mathrm{PO}_{4}^{3-}$ structures were refined to resolutions of $1.37 \AA$ and $1.55 \AA$, respectively. The native SynArsC was modelled and refined with a final $R_{\text {work }}$ of 0.166 and an $R_{\text {free }}$ of 0.194 . The final $R_{\text {work }}$ and $R_{\text {free }}$ for SynArsC-PO ${ }_{4}^{3-}$ structure were 0.152 and 0.184 , respectively.

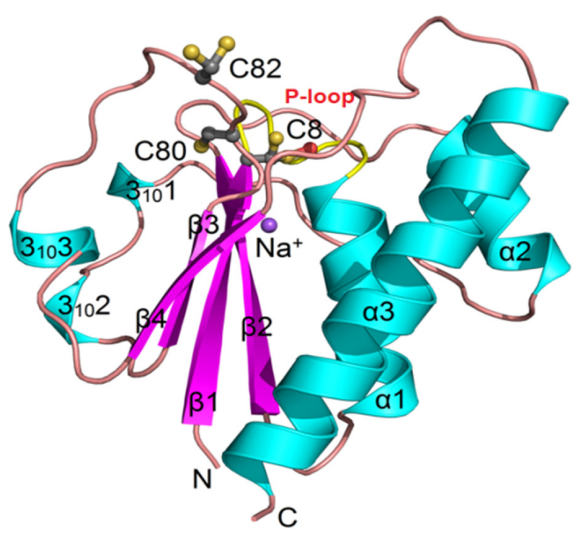

Figure 1. The overall structure of SynArsC shown as cartoon representations. Key residues are shown in stick representation. The P-loop is colored yellow.

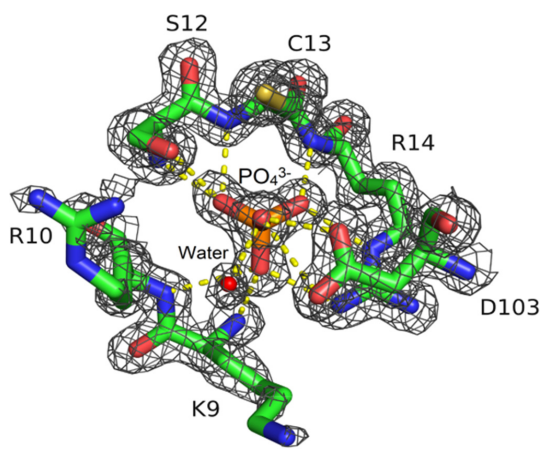

Figure 2. The binding site in the SynArsC- $\mathrm{PO}_{4}^{3-}$ structure. The $2 F_{o b s}-F_{\text {calc }}$ density map was calculated from the refined model contoured at $1.0 \sigma$.

\subsection{Overall structure of SynArsC}

SynArsC showed similar structure with Trx-dependent ArsCs, consisting of a four-stranded and parallel opentwisted $\beta$-sheet $(\beta 1-4)$ flanked by three major $\alpha$ helices $(\alpha 1-3)$ and three small $3_{10}$-helices $\left(3_{10} 1-3\right)$ on both sides (Fig. 1).

In the structure of SynArsC, the conserved $\mathrm{P}$-loop connecting the first $\beta$-sheet with $\alpha$-helix is an active site of both phosphatases and arsenate reductases. The first conserved cysteine (cys8) was in the P-loop. However, the other active residues were in unique geometries, with the last two conserved cysteines (cys80 and cys82) locating in the flexible loop and the conserved aspartic acid (Asp103) being in the rigid area.

\subsection{The phosphate-binding site}

$\mathrm{PO}_{4}^{3-}$ is tightly hydrogen-bound to the P-loop in the SynArsC- $\mathrm{PO}_{4}^{3-}$ structure (Fig. 2). The P-loops are almost in the same geometry with Asn11 in the $\alpha \mathrm{L}$ conformation with or without binding to $\mathrm{PO}_{4}^{3-}$. Therefore, the biding of $\mathrm{PO}_{4}^{3-}$ does not remarkably change the conformation of SynArsC. However, it does make the structure more stable. The detailed snapshot also provides insight into the catalytic mechanism of SynArsC.

\section{CONCLUSIONS}

SynArsC showed similar structure with Trx-coupled ArsCs, but also has its own particularity in structure as a member of new arsenate reductase family.

\section{ACKNOWLEDGEMENTS}

This work is supported by the National Natural Science Foundation of China (21507125 and 31270161).

\section{REFERENCES}

López-Maury, L., Sánchez-Riego, A.M., Reyes, J.C. \& Florencio, F.J. 2009. The glutathione/glutaredoxin system is essential for arsenate reduction in Synechocystis sp. strain PCC 6803. J. Bacteriol. 191: 3534-3543.

Li, R., Haile, J.D. \& Kennelly, P.J. 2003. An arsenate reductase from Synechocystis sp. strain PCC 6803 exhibits a novel combination of catalytic characteristics. J. Bacteriol. 185: 6780-6789.

Messens, J. \& Silver, S. 2006. Arsenate reduction: thiol cascade chemistry with convergent evolution. J. Mol. Biol. 362: 1-17.

Yu, C., Xia, B. \& Jin, C. 2011. ${ }^{1} \mathrm{H},{ }^{13} \mathrm{C}$ and ${ }^{15} \mathrm{~N}$ resonance assignments of the arsenate reductase from Synechocystis sp. strain PCC 6803. Biomol. NMR Assignm. 5: 85-87.

Zhu, Y.G., Xue, X.M., Kappler, A., Rosen, B.P. \& Meharg A.A. 2017. Linking genes to microbial biogeochemical cycling: lessons from arsenic. Environ. Sci. Technol. 51(13): 7326-7339. 


\title{
Impacts of environmental factors on arsenate biotransformation and release in Microcystis aeruginosa using Taguchi experimental design
}

\author{
Z.H. Wang ${ }^{1,2}$, Z.X. Luo $^{2}$ \& C.Z. Yan ${ }^{2}$ \\ ${ }^{1}$ College of Chemistry and Environment, Fujian Province Key Laboratory of Modern Analytical Science and \\ Separation Technology, Minnan Normal University, Zhangzhou, China \\ ${ }^{2}$ Key Laboratory of Urban Environment and Health, Institute of Urban Environment, Chinese Academy of Sciences, \\ Xiamen, China
}

\begin{abstract}
We conducted a series of experiments using Taguchi methods to determine optimum conditions for arsenic (As) biotransformation. We found that $\mathrm{N}$ is critical for $M$. aeruginosa $\mathrm{As}(\mathrm{V})$ biotransformation, particularly with regard to As(III) transformation. Also, As accumulation benefited from low P levels when combined with high $\mathrm{N}$ concentrations. Phosphate was second to $\mathrm{As}(\mathrm{V})$ as the primary factor to affect As accumulation. Additionally, we found that the small amounts of As that accumulated under low concentrations of As and high $\mathrm{P}$ were tightly stored in living algal cells and were easily released after cell death. Our results will be helpful for the understanding, practical applications, and overall control of the key environmental factors, particularly those associated with algal bioremediation for As-polluted water.
\end{abstract}

\section{INTRODUCTION}

Algae are widely distributed in aquatic ecosystems and play an important role in arsenic (As) bioaccumulation and biogeochemical cycling (Duncan et al., 2015; Yan et al., 2016). Microcystis aeruginosa is generally tolerant to $\mathrm{As}(\mathrm{V})$ and exhibits a stronger As bioaccumulation capacity compared to other freshwater algae (Wang et al., 2017). Many abiotic factors affect the metabolic functions of alga contaminated by As, such as As levels, hydrogen ion levels $(\mathrm{pH})$, and key nutrient concentrations of nitrogen $(\mathrm{N})$ and phosphorus $(\mathrm{P})$ in culture media. To date, very limited information is available on how and to what extent environmental factors influence arsenic (As) biotransformation and release in freshwater algae. To further understand environmental factors that impact $\mathrm{As}(\mathrm{V})$ uptake, we investigated As biotransformation and release in $M$. aeruginosa, aspects of its growth, intracellular As accumulation in algae cells, and release after algae death. Taguchi methods under their relevant statistical assumptions were applied to determine optimum environmental conditions.

\section{METHODS}

\subsection{Experimental design}

Three different levels in combination with actual aquatic conditions of each environmental factor were considered (Table 1). Accordingly, we chose an L9 $\left(3^{4}\right)$ orthogonal array, and we obtained experimental conditions (Table 2 ) by combining Table 1 and the L9 $\left(3^{4}\right)$ orthogonal array. We used experimental data to determine optimal experimental conditions and evaluate experimental results, which we assessed using
Table 1. Environmental factors of the orthogonal test.

\begin{tabular}{lllrr}
\hline Factor & $\begin{array}{l}\mathrm{NO}_{3}^{-}-\mathrm{N} \\
\left(\mathrm{mg} \mathrm{L}^{-1}\right)\end{array}$ & $\begin{array}{l}\mathrm{PO}_{4}^{3-}-\mathrm{P} \\
\left(\mathrm{mg} \mathrm{L}^{-1}\right)\end{array}$ & $\mathrm{pH}$ & $\begin{array}{r}A s(\mathrm{~V}) \\
(\mu \mathrm{M})\end{array}$ \\
\hline Level 1 & 2 & 0.02 & 6 & 0.1 \\
Level 2 & 4 & 0.20 & 8 & 1.0 \\
Level 3 & 10 & 1.00 & 10 & 10.0 \\
\hline
\end{tabular}

Table 2. Experimental L $9\left(3^{4}\right)$ orthogonal array.

\begin{tabular}{|c|c|c|c|c|}
\hline \multirow[b]{2}{*}{ Treatment } & \multicolumn{4}{|c|}{ Parameters } \\
\hline & $\begin{array}{l}\mathrm{NO}_{3}^{-}-\mathrm{N} \\
\left(\mathrm{mg} \mathrm{L}^{-1}\right)\end{array}$ & $\begin{array}{l}\mathrm{PO}_{4}^{3-}-\mathrm{P} \\
\left(\mathrm{mg} \mathrm{L}^{-1}\right)\end{array}$ & $\mathrm{pH}$ & $\begin{array}{l}A s(\mathrm{~V}) \\
\mu \mathrm{M}\end{array}$ \\
\hline E1 & 2 & 0.02 & 6 & 0.1 \\
\hline E2 & 2 & 0.2 & 8 & 1.0 \\
\hline E3 & 2 & 1.0 & 10 & 10 \\
\hline E4 & 4 & 0.02 & 8 & 10 \\
\hline E5 & 4 & 0.2 & 10 & 0.1 \\
\hline E6 & 4 & 1.0 & 6 & 1.0 \\
\hline E7 & 10 & 0.02 & 10 & 1.0 \\
\hline E8 & 10 & 0.2 & 6 & 10 \\
\hline E9 & 10 & 1.0 & 8 & 0.1 \\
\hline
\end{tabular}

analysis of variance (ANOVA) and the signal-to-noise $(\mathrm{S} / \mathrm{N})$ ratio with biggest characteristics.

\subsection{Batch culture preparation}

The $M$. aeruginosa cultures that we used were incubated in BG-11 without adding additional $\mathrm{N}$ and $\mathrm{P}$ for $48 \mathrm{~h}$ after exponential phases of algal suspension growth were centrifuged and washed twice in sterile Milli-Q water. We separated the above cultures into nine equal parts, which were once again centrifuged and washed in sterile Milli-Q water. They were aseptically transferred to nine sterile $1 \mathrm{~L}$ Erlenmeyer flasks 


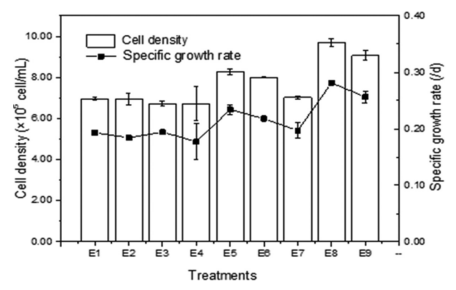

Figure 1. Cell density and the specific growth rate of M. aeruginosa under different treatments.

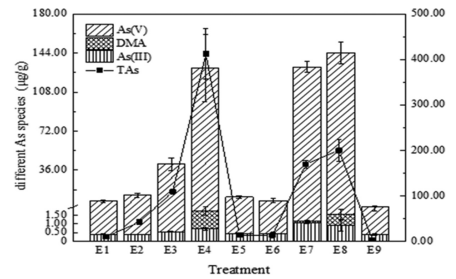

Figure 2. Intracellular total As and different As species concentrations in $M$. aeruginosa under different treatments.

( 2 replicates per treatment), containing $250 \mathrm{~mL}$ of different autoclaved sterilized modified BG-11 media, according to Table 2 . After cultured batch treatments in an illuminated incubator shaker for $96 \mathrm{~h}$, We then harvested approximately $20 \mathrm{~mL}$ of the algae via centrifugation at $4500 \times \mathrm{g}$ for $10 \mathrm{~min}$. Media was also frozen to determine total As (TAs) and the specific As species.

\section{RESULTS AND DISCUSSION}

\subsection{Algae growth}

The final cell density and specific growth rate obtained at the conclusion of the $96 \mathrm{~h}$ experiment were plotted in Figure 1, which further indicated variation in parameter level combinations. $\mathrm{NO}_{3}^{-}-\mathrm{N}$ was found to be the most influential among the four factors on algal growth while $\mathrm{PO}_{4}^{3-}-\mathrm{P}$ was the second most influential factor.

\subsection{Intracellular arsenic bioaccumulation}

We ascertained TAs content and As species in algal cells after $96 \mathrm{~h}$ in culture media (Fig. 2). High As bioaccumulation and its facilitation by $\mathrm{N}$ in media indicated that $\mathrm{N}$ could affect algae bioremediation in As polluted water. M. aeruginosa could accumulate greater $\mathrm{As}(\mathrm{V})$ in cells under high $\mathrm{As}(\mathrm{V})$ ambient concentrations, coexisting with low $\mathrm{P}$ and high $\mathrm{N}$ concentrations. Being key factors affecting intracellular TAs and $\mathrm{As}(\mathrm{V})$ accumulation, their similarity in chemical properties between $P$ and As determined that $P$ was second to As in rank and order.

\subsection{Arsenic biotransformation in media}

With the exception of $A s(\mathrm{~V})$, we detected $A s$ biotransformation and DMA in media after $96 \mathrm{~h}$ in algal culture (Fig. 3). Although high $A s(\mathrm{III})$ and DMA concentrations in media were primarily caused by the high $A s(\mathrm{~V})$ levels, its reduction to $A s(\mathrm{III})$ in media was

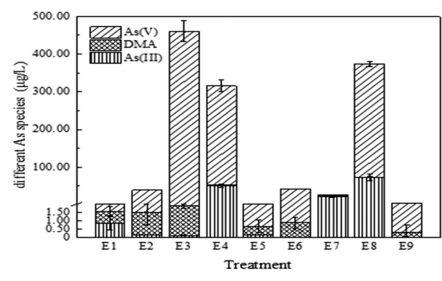

Figure 3. Different As species concentrations in culture media under different treatments.

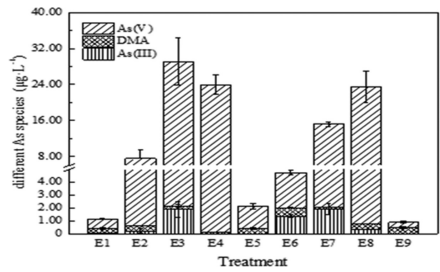

Figure 4. Different As species concentrations in culture media from dead algae cells under different treatments.

inclined to occur in high $N$ and low $P$ concentrations under slightly acidic environments. As the principal factor, $N$ exhibited a significantly positive effect on $A s$ (III) concentrations in culture media after $A s$ was introduced.

\subsection{Arsenic release from dead algae}

This study found that As was rapidly released from dead algal cells. Figure 4 shows that approximately $58 \%$ to $93 \%$ As was released after $8 \mathrm{~h}$ resuspension. The high As uptake in algae with increasing initial concentrations of As $(\mathrm{V})$ could result in high As efflux from dead cells. The $\mathrm{pH}$ factor yielded principal effects on As(III) and methylated As (OAs) efflux.

\section{ACKNOWLEDGMENTS}

This study was jointly supported by the National Nature Science Foundation of China (project nos. 41401552, 41271484 and 21277136) and the Nature Science Foundation of Fujian Province (2016J01691).

\section{REFERENCES}

Duncan, E.G., Maher, W.A. \& Foster, S.D. 2015. Contribution of arsenic species in unicellular algae to the cycling of arsenic in marine ecosystems. Environ. Sci. Technol. 49(1): 33-50.

Wang, Z. H., Luo, Z. X., Yan, C. Z. \& Xing, B. S. 2017. Impacts of environmental factors on arsenate biotransformation and release in Microcystis aeruginosa using the Taguchi experimental design approach. Water Res. 118: $167-176$.

Yan, C.Z., Che, F.F., Zeng, L.Q., Wang, Z.S., Du, M.M., Wei, Q.S., Wang, Z.H., Wang, D.P. \& Zhen, Z. 2016. Spatial and seasonal changes of arsenic species in Lake Taihu in relation to eutrophication. Sci. Total Environ. 563-564: 496-505. 


\title{
Elevated oxidizing compounds influencing the biogeochemistry of arsenic in subsurface environments
}

\author{
W.J. Sun \\ Department of Civil and Environmental Engineering, Southern Methodist University, Dallas, Texas, USA
}

\begin{abstract}
Arsenic contamination of groundwater and surface water is a worldwide problem, which poses health risks to millions of people in the world. The arsenic in the groundwater is of natural origin, and is released from the weathering of arsenic bearing minerals into the groundwater, owing to the anaerobic conditions of the subsurface. In this study, the oxidation of arsenite $(\mathrm{As}(\mathrm{III}))$ to arsenate $(\mathrm{As}(\mathrm{V}))$ linked to oxidizing compounds under anoxic conditions was shown to be a widespread microbial activity in anaerobic sludge and sediment samples that were not previously exposed to arsenic contamination. The results indicate that microbial oxidation of $\mathrm{As}(\mathrm{III})$ and $\mathrm{Fe}$ (II) linked to denitrification resulted in the enhanced immobilization of aqueous arsenic in anaerobic environments by forming Fe(III) (hydr)oxide coated sands with adsorbed As(V). Thus, the elevated oxidizing compounds could play critical roles in influencing the biogeochemistry of arsenic in subsurface environments.
\end{abstract}

\section{INTRODUCTION}

Arsenic contamination of groundwater and surface water is a worldwide problem, which poses the health risks to millions of people in the world (Smedley \& Kinniburgh, 2002). The arsenic in the groundwater is largely of natural origin, and is released from the weathering of arsenic bearing minerals into the groundwater, owing to the anoxic conditions of the subsurface. As presented in Figure 1, microbiological processes play significant roles in controlling the fate and transport of arsenic in the natural environments. Under reducing conditions, microbial reduction of arsenate $(\mathrm{As}(\mathrm{V}))$ to arsenite $(\mathrm{As}(\mathrm{III}))$ and ferric (hydr)oxides to soluble Fe(II) are considered as the dominant mechanisms of arsenic mobilization in subsurface environments. On the other hand, if oxidizing conditions can be restored, arsenic can be immobilized by the formation of $\mathrm{As}(\mathrm{V})$ and ferric (hydr)oxides. As $(\mathrm{V})$ is more strongly adsorbed than As(III) at circum-neutral conditions by common non-iron metal oxides in sediments such as those of aluminium. Ferric (hydr)oxides have strong affinity

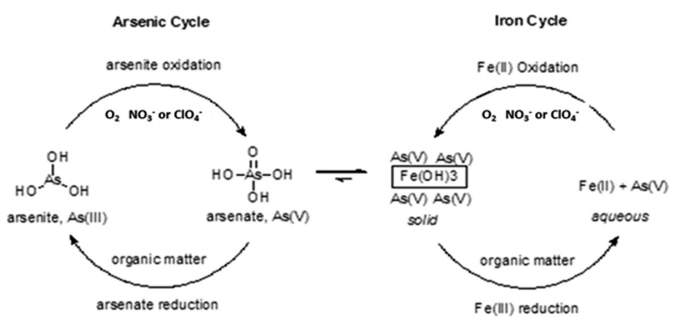

Figure 1. Biogeochemical redox cycles of arsenic and iron. for both $\mathrm{As}(\mathrm{III})$ and $\mathrm{As}(\mathrm{V})$ in circum-neutral environments. Nitrate or (per)chlorate can be considered as alternative oxidants with advantages over elemental oxygen due to their high aqueous solubility and lower chemical reactivity which together enable them to be better dispersed in the saturated subsurface. The main objective of this study was to illustrate the importance of anoxic oxidation of As(III) and Fe(II) linked to oxidizing compounds (nitrate or (per)chlorate) under anoxic conditions in the biogeochemical cycle of arsenic.

\section{METHODS/EXPERIMENTAL}

\subsection{Microorganisms}

Sludge and sediment samples obtained from different sources, including aerobic activated sludge and anaerobically digested sewage sludge, methanogenic granular sludges, and pond sediments, were used as inocula.

\subsection{Batch bioassay}

Batch bioassays were performed under anoxic conditions in serum flasks that were supplied with $120 \mathrm{~mL}$ of a basal mineral medium ( $\mathrm{pH}$ 7.0-7.2) containing bicarbonate as the only carbon source. The medium was also supplemented with As(III) as the electron donor and nitrate (typically $10 \mathrm{mM}$, unless otherwise specified) as the electron acceptor. Various controls (e.g., abiotic controls, killed sludge controls, controls without electron acceptor) were applied based on the requirements of each experiment. All assays were conducted in triplicate. 
Table 1. Summary of microbial As(III) oxidation under denitrifying conditions.

\begin{tabular}{|c|c|c|c|c|}
\hline \multicolumn{2}{|c|}{ Inoculum } & \multicolumn{2}{|c|}{$\mathrm{As}(\mathrm{V})$ formation } & \multirow{2}{*}{$\begin{array}{l}\text { Time } \\
\text { Days }\end{array}$} \\
\hline Name & Sources & With $\mathrm{NO}_{3}^{-}$ & $\begin{array}{l}\text { Without } \\
\mathrm{NO}_{3}^{-}\end{array}$ & \\
\hline NGS & $\begin{array}{l}\text { Industrial } \\
\text { UASB reactor }\end{array}$ & $0.423 \pm 0.004$ & ND & 6 \\
\hline EGS & $\begin{array}{l}\text { Industrial } \\
\text { UASB reactor }\end{array}$ & ND & ND & ND \\
\hline ADS & $\begin{array}{l}\text { Anaerobic } \\
\text { digested sludge }\end{array}$ & $0.425 \pm 0.003$ & ND & 13 \\
\hline RAS & $\begin{array}{l}\text { Aerobic } \\
\text { activated sludge }\end{array}$ & ND & ND & ND \\
\hline TDE & $\begin{array}{l}\text { Thiosulfate- } \\
\text { oxidizing denitrifier }\end{array}$ & $0.416 \pm 0.002$ & ND & 10 \\
\hline DPS & Lake sediment & $0.415 \pm 0.003$ & ND & 6 \\
\hline WCS & $\begin{array}{l}\text { Winogradsky } \\
\text { column }\end{array}$ & $0.413 \pm 0.001$ & ND & 5 \\
\hline PCS & $\begin{array}{l}\text { Pinal creek } \\
\text { sediment }\end{array}$ & $0.295 \pm 0.020$ & $\begin{array}{l}0.298 \pm \\
0.014\end{array}$ & $>14$ \\
\hline
\end{tabular}

ND: Not Detected

\subsection{Column study}

Anoxic As(III) and Fe(II) oxidation under denitrifying conditions was investigated in two glass sand packed bed columns that were fed continuously with synthetic basal medium and inoculated with As(III)oxidizing denitrifying culture. The treatment column (SF1) was the biologically active column inoculated with chemolithotrophic As(III)-oxidizing denitrifying bacteria and fed with basal medium, As(III) $(0.5 \mathrm{mg}$ $\left.\mathrm{L}^{-1}\right)$ and $\mathrm{Fe}(\mathrm{II})\left(20 \mathrm{mg} \mathrm{L}^{-1} \mathrm{Fe}\right)$ as electron donating substrates, nitrate $\left(155 \mathrm{mg} \mathrm{L}^{-1} \mathrm{NO}_{3}^{-}\right)$as the electron acceptor. The control column (SF2) was the same as SF1 but lacked nitrate in the medium.

\subsection{Analytical method}

$\mathrm{As}(\mathrm{III})$ and $\mathrm{As}(\mathrm{V})$ were analyzed by ion chromatography-inductively coupled plasma-mass spectroscopy (HPLC-ICP-MS). Nitrate and nitrite were analyzed by suppressed conductivity ion chromatography using a Dionex 3000 system. Other analytical determinations (e.g., pH, TSS, VSS) were conducted according to standard methods (APHA, 1999).

\section{RESULTS AND DISCUSSION}

\subsection{Batch results}

Sediments and sludge samples from environments not known to be contaminated with arsenic were incubated with $\mathrm{As}(\mathrm{III})$ either in the presence and absence of $\mathrm{NO}_{3}^{-}$ and were incubated in the absence of elemental oxygen. As presented in Table 1, six out of the eight inocula tested displayed microbial activity towards the anoxic oxidation of As(III) by nitrate. Five out of the six positive samples showed a dependency on the presence of $\mathrm{NO}_{3}^{-}$for the anoxic oxidation of As(III). One of
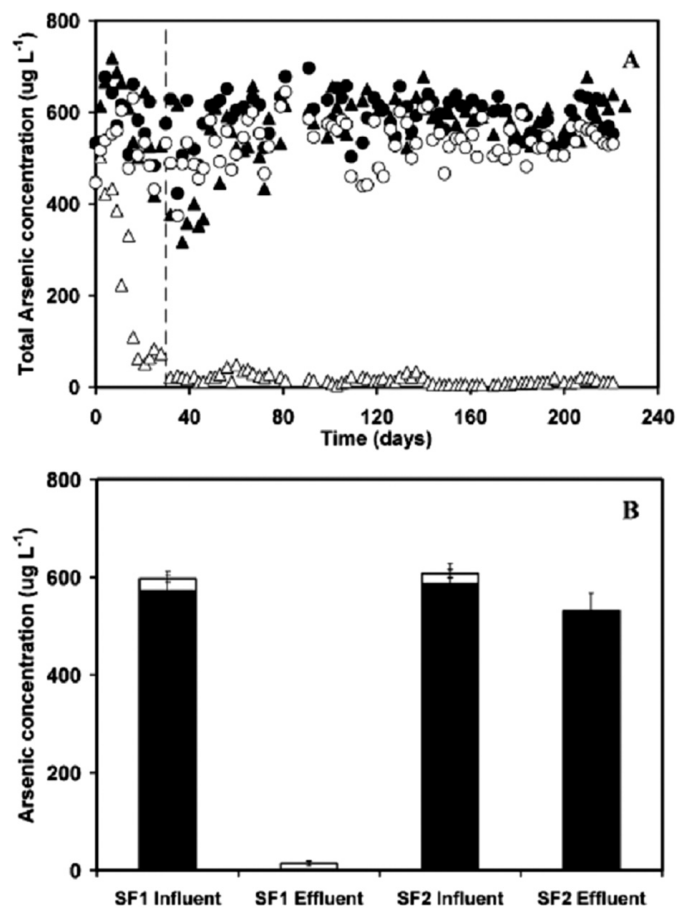

Figure 2. (A) Removal of soluble total As in two sand packed columns fed with $6.67 \mu \mathrm{M} \mathrm{As}(\mathrm{III})$ and $360 \mu \mathrm{M} \mathrm{Fe}(\mathrm{II})$. Column SF1 (fed with $2.5 \mathrm{mM}$ nitrate): $(\boldsymbol{\Delta})$ influent, $(\Delta)$ effluent. Column SF2 (without nitrate): (•) influent, (o) effluent. The dashed line indicates the day when the steady state operation was achieved. (B) Arsenic speciation in the influent and effluent of sand packed columns SF1 or SF2: As(III) (solid bars) and $\mathrm{As}(\mathrm{V})$ (empty bars).

the positive samples, PCS, had this activity both in the presence and absence of added $\mathrm{NO}_{3}^{-}$, which may have been due to high levels of oxidized manganese species known to occur in that sediment (Lind \& Hem, 1993). The average molar yield of nitrate linked As(III) oxidation was $0.94 \pm 0.04 \mathrm{~mol} \mathrm{As} \mathrm{V})$ formed $\mathrm{mol}^{-1} \mathrm{As}(\mathrm{III})$ consumed and the value for the PCS sediment was similar. The results demonstrated that the anoxic oxidation of $\mathrm{As}(\mathrm{III})$ to $\mathrm{As}(\mathrm{V})$ linked to denitrification is a widespread microbial activity in anaerobic sludge and sediment samples that were not previously exposed to arsenic contamination.

\subsection{Column results}

The oxidation of As(III) linked to the use of commonoccurring nitrate as an electron acceptor may be an important missing link in the biogeochemical cycling of arsenic. Thus, a bioremediation strategy was explored that is based on utilizing nitrate to support the microbial oxidation of $\mathrm{Fe}$ (II) and As(III) in the subsurface as a means to immobilize arsenic. Continuous flow columns packed with sand were used to simulate a natural anaerobic groundwater and sediment system with co-occurring $\mathrm{As}(\mathrm{III})$ and $\mathrm{Fe}(\mathrm{II})$ in 
the presence (column SF1) or absence (column SF2) of nitrate, respectively.

The time-course of the influent and effluent total soluble arsenic concentrations from the two columns is illustrated in Figure 2A. The result shows that the release of soluble As was greater in SF2 compared to SF1, which is in accordance with the expected adsorption of As on the $\mathrm{Fe}$ (III) (hydr)oxides formed from anoxic $\mathrm{Fe}(\mathrm{II})$ oxidation. Figure 2B illustrates the average soluble arsenic species in the influent and effluent of columns SF1 and SF2 during the steady state period of operation from day 30 onward. The results show that $99.7 \% \mathrm{As}(\mathrm{III})$ was eliminated from column SF1 and that it was not recovered as soluble $\mathrm{As}(\mathrm{V})$ in the effluent. In contrast, As(III) removal was marginal (9.7\%) in the control column lacking nitrate (SF2). The results suggest that no adsorption had occurred, consistent with the low retention of $\mathrm{Fe}$ in the column.

\section{CONCLUSIONS}

Microbial oxidation of As(III) and Fe(II) by denitrifying microorganisms led to the formation of ferric (hydroxides) which adsorbed $\mathrm{As}(\mathrm{V})$ formed from As(III)-oxidation. The studies demonstrated that anoxic microbial oxidation of As(III) and Fe(II) linked to denitrification significantly enhance the immobilization of arsenic in the anaerobic subsurface environments and may reduce the risk of arsenic contaminated water to public health and environmental ecological systems.

\section{ACKNOWLEDGEMENTS}

The work presented here was funded by a USGS, National Institute for Water Resources 104G Grant (2005AZ114G) and by a grant of the NIEHSsupported Superfund Basic Research Program (NIH ES-04940).

\section{REFERENCES}

APHA. 1999. Standard methods for the examination of water and wastewater, twentieth ed. American Public Health Association, Washington, DC.

Lind, C.J. \& Hem, J.D. 1993. Manganese minerals and associated fine particulates in the streambed of Pinal Creek, Arizona, USA: a mining-related acid drainage problem. Appl. Geochem. 8 (1): 67-80.

Smedley, P.L. \& Kinniburgh, D.G. 2002. A review of the source, behaviour and distribution of arsenic in natural waters. Appl. Geochem. 17 (5): 517-568. 


\title{
Multiple species of arsenic biotransformation occur in Nostoc sp. PCC 7120
}

\author{
X.M. Xue \& Y.G. Zhu \\ Key Lab of Urban Environment and Health, Institute of Urban Environment, \\ Chinese Academy of Sciences, Xiamen, China
}

\begin{abstract}
Nostoc cells incubated with arsenite (As(III)) for two weeks were extracted with dichloromethane/methanol (DCM/MeOH) and the extract was partitioned between water and DCM. Arsenic species in aqueous and DCM layers were determined using high performance liquid chromatography - inductively coupled plasma mass spectrometer/electrospray tandem mass spectrometry (HPLC-ICPMS/ESIMSMS). In addition to inorganic arsenic (iAs), the aqueous layer also contained monomethylarsonate (MAs(V)), dimethylarsinate (DMAs(V)), and the two arsenosugars, namely a glycerol arsenosugar (Oxo-Gly) and a phosphate arsenosugar $\left(\mathrm{Oxo}-\mathrm{PO}_{4}\right)$. Two major arsenosugar phospholipids (AsSugPL982 and AsSugPL984) were detected in DCM fraction. Arsenic in the growth medium was also investigated by HPLC/ICPMS and shown to be present mainly as the inorganic forms As(III) and As(V) accounting for $29 \%-38 \%$ and $29 \%-57 \%$ of the total arsenic, respectively. The total arsenic of methylated arsenic, arsenosugars, and arsenosugar phospholipids in Nostoc cells with increasing As(III) exposure were not markedly different, indicating that the transformation to organoarsenic in Nostoc was not dependent on As(III) concentration in the medium.
\end{abstract}

\section{INTRODUCTION}

Arsenic (As) is a ubiquitous and carcinogenic toxic element, and has both acute and chronic toxicity effects on humans. The bioavailability of arsenic and its resultant toxicity are influenced to a great extent by its species. ${ }^{1}$ Inorganic arsenic, the major form of arsenic in water and soils, is transformed into organic arsenic species or in reverse in natural biological processes, and microorganisms play a critical role in arsenic biogeochemical cycle (Zhu et al., 2014).

Cyanobacteria are involved in arsenic biogeochemical cycle, and have been reported to have the ability to methylate inorganic arsenic, producing arsenosugars and arsenosugar phospholipids. The previous studies showed that Nostoc methylated As(III) to DMAs(V) and TMA(O) (Yin et al., 2011), demethylated MAs(V) and MAs(III) into As(III) (Yan et al., 2015), and produced Oxo-Gly (Miyashita et al., 2012). In this study, HPLC-ICPMS/ESIMS was used to analyze arsenic biotransformation in Nostoc in order to understand arsenic biotransformation by Nostoc from multiple perspectives.

\section{METHODS/EXPERIMENTAL}

\subsection{Fractionation of arsenic in Nostoc}

About $30 \mathrm{mg}$ of freeze-dried cells were weighed (to a precision of $0.1 \mathrm{mg}$ ) directly into a centrifuge tube $(15 \mathrm{~mL}$, polypropylene), $5 \mathrm{~mL}$ of a mixture of $\mathrm{DCM} / \mathrm{MeOH}(2+1, \mathrm{v} / \mathrm{v})$ was added. The mixture was extracted on a rotary wheel overnight, and centrifuged at $4754 \mathrm{~g}$ and $4{ }^{\circ} \mathrm{C}$ for 15 minutes. $0.5 \mathrm{~mL}$ of $1 \%$ aqueous $\mathrm{NH}_{4} \mathrm{HCO}_{3}$ solution was added to the supernatant $(\sim 4.5 \mathrm{~mL})$, the solution was separated into an aqueous layer (upper layer, $\mathrm{MeOH}$ and $\mathrm{H}_{2} \mathrm{O}$ ) and $\mathrm{DCM}-\mathrm{MeOH}$ layer (lower layer).

\subsection{HPLC-ICPMS/ESIMSMS analysis of water-soluble arsenic species and arsenolipids}

Separation was performed under reversed-phase conditions using a Shodex Asahipak C8P-50 4D column $(4.6 \times 150 \mathrm{~mm}, 5 \mu \mathrm{m}$ particle size $)$. The column effluent was split using a passive splitter with $80 \%$ being transferred directly to the ESI-MSMS. The remaining $20 \%$ of the split flow was transferred to the ICPMS together with a support flow of water containing 1\% formic acid and $20 \mu \mathrm{g} \mathrm{L}^{-1} \mathrm{Ge}$, In, Te $\left(0.3 \mathrm{~mL} \mathrm{~min}^{-1}\right)$ introduced through a T-piece after the splitter.

\section{RESULTS AND DISCUSSION}

\subsection{Results}

Arsenic species in the aqueous layers were analyzed, and revealed that two arsenosugars were produced by Nostoc. The relative proportion of arsenosugars in total aqueous arsenic species in Nostoc cells was $0.5 \%-$ $13 \%$ for Oxo-Gly and $0.7 \%-8 \%$ for $\mathrm{Oxo}-\mathrm{PO}_{4}$, and decreased with increasing As(III) exposure.

HPLC/ICPMS analysis of the DCM fraction showed the presence of arsenolipids, and analysis by ESMSMS revealed that the $[\mathrm{M}+\mathrm{H}]^{+}$of two main arsenic-containing compounds were 983 and 985. The chromatographic behavior was the same as that reported previously for arsenosugar phospholipids 
$\left(\mathrm{C}_{47} \mathrm{H}_{88} \mathrm{O}_{14} \mathrm{AsP}\right.$ (As-PL982) and $\mathrm{C}_{47} \mathrm{H}_{90} \mathrm{O}_{14} \mathrm{AsP}$ (AsPL984) in Synechocystis sp. PCC 6803 and brown macroalgae.

\subsection{Discussion}

Multiple species of arsenic biotransformation pathways co-occur in Nostoc. Microbes have evolved various mechanisms to utilize or detoxify arsenic. Known mechanisms include arsenic redox changes, arsenic methylation and demethylation, As(III) efflux, and the production of complex organoarsenic. Arsenic reduction and efflux are always considered as significant arsenic detoxification in microorganisms. The previous proteomics analysis of Nostoc under $\operatorname{As}(\mathrm{V})$ stress showed that the expression of two genes, alr1097 (encoding an As(III) efflux protein; arsB) and alr1105 (encoding an $\mathrm{As}(\mathrm{V})$ reductase; $\operatorname{ars} C$ ), was up-regulated, (Pandey, et al., 2012), illustrating that Nostoc was capable of performing $\mathrm{As}(\mathrm{V})$ uptake, As(V) reduction, and As(III) excretion. Similar results were also found in cyanobacteria Synechocystis sp. PCC 6803 and Microcystis aeruginosa, some globally significant picocyanobacteria Prochlorococcus also were reported to have genomic potential for $\mathrm{As}(\mathrm{V})$ reduction and As(III) efflux. (Saunders \& Rocap 2015). Yin et al. (2011) investigated the ability of arsenic methylation by Nostoc and arsenic(III) S-adenosylmethionine methyltransferase (ArsM) from Nostoc by chemotrapping volatile TMAs(III). Moreover, our other study showed that Nostoc was able to demethylate MAs(III) rapidly to As(III) using ArsI that is a C.As lyase responsible for MAs(III) demethylation, and also could demethylate $\mathrm{MAs}(\mathrm{V})$ slowly to As(III), (Yan et al., 2015) suggesting that MAs(V) reduction and MAs(III) demethylation occurred in Nostoc. However, MAs(III) oxidation in Nostoc cannot be regarded to be catalyzed by an enzyme because ArsH homologous compound oxidizing MAs(III) (Chen, et al., 2015) was not found via blasting against the Nostoc proteome with ArsH of Synechocystis sp. PCC 6803, (Xue et al., 2014) and we did not ensure that there was As(III) oxidation catalyzed by As(III) oxidase in Nostoc because most of As(III) was oxidized by oxygen after long time culture and there was not As(III) oxidase identified in Nostoc. In addition, Nostoc was found to produce low quantities of arsenosugars and arsenolipids.

An abbreviated biosynthesis pathway of arsenosugar phospholipids in Nostoc was hypothesized as described in Figure 1. The methyl groups from S-adenosyl-L-methionine (SAM) are transferred to $\mathrm{As}(\mathrm{III})$ (which is absorbed directly by cells or arises from $\mathrm{As}(\mathrm{V})$ reduced by $\mathrm{Ars} C)$, by ArsM to produce trivalent methylated arsenic. Some of MAs(III) and DMAs(III) bound to ArsM are further methylated into DMAs(III) and TMAs(III). In addition, the adenosyl group from SAM is transferred to DMAs(III) falling off ArsM to generate the key intermediate of arsenosugar synthesis, namely dimethylarsinyladenosine (AsAd). AsAd undergoes glycosidation to produce Oxo-Gly which acts as a precursor to $\mathrm{Oxo}-\mathrm{PO}_{4}$

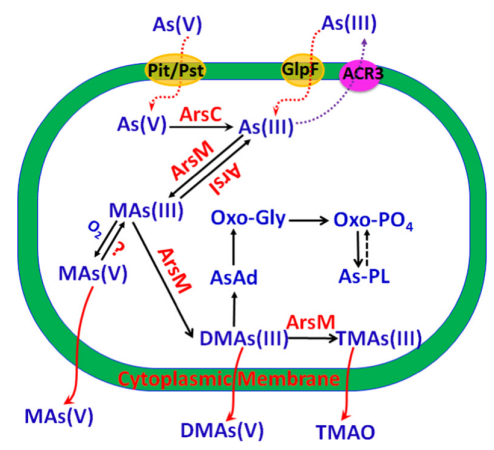

Figure 1. Arsenic metabolism and potential biosynthetic pathways of arsenosugar phospholipids in Nostoc.

produced later by cyanobacteria. Finally, fatty cids were added to $\mathrm{Oxo}-\mathrm{PO}_{4}$ to produce arsenosugar phospholipids by unknown enzymes.

In summary, our study revealed that the model organism cyanobacterium Nostoc can produce Oxo$\mathrm{PO}_{4}$ and arsenosugar phospholipids when exposed to $\mathrm{As}(\mathrm{III})$, and the production of complex organoarsenic and arsenic demethylation co-exist in Nostoc.

\section{ACKNOWLEDGEMENTS}

Our research is supported by the National Natural Science foundation of China (21507125).

\section{REFERENCES}

Chen, J., Bhattacharjee H., \& Rosen B.P. 2015. ArsH is an organoarsenical oxidase that confers resistance to trivalent forms of the herbicide monosodium methylarsenate and the poultry growth promoter roxarsone. Mol. Microbiol. 96(5): 1042-1052.

Miyashita, T., Oda Y., Horiuchi, J., Yin, J.C., Morimoto, T. \& Saitoe M. 2012. $\mathrm{Mg}^{2+}$ block of Drosophila NMDA receptors is required for long-term memory formation and CREB-dependent gene expression. Neuron. 74(5): 887-98.

Pandey, S., Rai, R. \& Rai, L.C. 2012. Proteomics combines morphological, physiological and biochemical attributes to unravel the survival strategy of anabaena Sp. PCC7120 under arsenic stress. J Proteomics. 75(3): 921-937.

Saunders, J. K. \& Rocap, G. 2015. Genomic potential for arsenic efflux and methylation varies among global prochlorococcus populations. The ISME Journal 10(1): 197-209.

Xue, X.M., Yan, Y., Xu, H.J., Wang, N., Zhang, X. \& Ye, J. 2014. ArsH from synechocystis Sp. PCC 6803 reduces chromate and ferric iron. FEMS Microbiol Letters 356 (1): 105-12.

Yan, Y., Ye, J., Xue, X.M. \& Zhu, Y.G. 2015. Arsenic demethylation by a C A As cyase in cyanobacterium nostoc Sp. PCC 7120. Environ. Sci. Technol. 49: 14350-58.

Yin, X.X., Chen, J., Qin, J., Sun, G.X., Rosen, B.P. \& Zhu Y.G. 2011. Biotransformation and volatilization of arsenic by three photosynthetic cyanobacteria. Plant Physiol. 156 (3): 1631-38.

Zhu, Y.G., Yoshinaga M., Zhao F.J. \& Rosen B.P. 2014. Earth abides arsenic biotransformations. Annu. Rev. Earth Plan. Sci. 42(1): 443-67. 